\title{
Reducing herbicide use in spring cereal production
}

\author{
JUKKA SALONEN \\ Agricultural Research Centre of Finland \\ Institute of Plant Protection \\ FIN-31600 Jokioinen, Finland
}

Academic dissertation

To be presented, with the permission of the Faculty of Agriculture and Forestry of the University of Helsinki, for public criticism in Viikki, Auditorium B2, on December 17th, 1993, at 12 o'clock noon. 



\section{PREFACE}

The research projects summarized in my thesis were conducted at the Agricultural Research Centre of Finland (ARC) during 1982-1992. I am most grateful to Dr. Leila-Riitta Erviö (Head of the Institute of Plant Protection), to Professor Emeritus Jaakko Mukula, and to the heads of the regional research stations of the ARC for providing the possibilities and facilities required to undertake the experiments. Dr. Erviö and Professor Mukula are especially acknowledged for being my teachers and supervisors in Weed Science.

I am indebted to Professor Emeritus Eero Varis, my teacher in Crop Science, for valuable instructions on my research subject and for encouragement during my post-graduate studies. I express my sincere gratitude to Professor Eija Pehu for her enthusiastic guidance and support during the last stages of the compilation of my thesis.

I am grateful to Professor Haldor Fykse and to Dr. Jari Peltonen, referees of the thesis, for their valuable advice and constructive criticism on the manuscript. I sincerely thank Dr. Alan Courtney, Mr. George Cussans and Mr. Per Kudsk whose relevant comments and suggestions greatly improved the manuscript of the introductory chapter. I also wish to thank my Nordic colleagues Professor Sigurd Håkansson and Professor Jens Streibig for fruitful discussions and guidance in Weed Science and statistics.

I give my warm thanks to the technical staff of the Weed Science Section of the ARC. Under the leadership of Mr. Kauko Aunola, Mrs. Eiramaija Tanni and Mr. Jari Poikulainen they collected a huge amount of data. I sincerely thank Mrs. Tarja Aurén-Karnaattu, Mr. Heikki Jalli and Mrs. Inkeri Tähkävuori for being the co-leaders of the field trials. I am indebted to my colleague Mrs. Sanni Junnila for sharing my duties at the Institute.

I wish to express my thanks to Ms. Elise Ketoja, Dr. Caspar Looman, Mrs. Liisa Mattila and Dr. Jukka Öfversten for guidance in statistics. I thank the staff of the Data and Information Services of the ARC for efficient co-operation. Especially, pleasant team work with Mrs. Sari Torkko, Co-Editor of this journal, is warmly acknowledged as it speeded up the compilation of my thesis. I am pleased to get my thesis published in this journal. Linguistic revision by Mrs. Sevastiana Ruusamo (original papers) and by Dr. Jonathan Robinson (introductory chapter) is sincerely acknowledged.

I am greatful for the financial support to our research projects from the Ministry of Agriculture and Forestry and from the Academy of Finland. I am pleased to acknowledge the special funds from the ARC, and personal scholarships from the Academy of Finland, the Agricultural Reseach Foundation of Tiura, the Finnish Association of Academic Agronomists, the Kemira Research Foundation and the Research and Science Foundation of Farmos.

My dearest thanks I owe to my wife Merja, M.Sc. in Soil Science, for being a demanding reviewer of my manuscripts and for her cheerful attitude and understanding while I was wrapped in my scientific thoughts. Both my wife and the KVARKA circle of friends have made a great effort in optimizing my life between work and leisure. 


\section{LIST OF ORIGINAL ARTICLES}

The thesis is a summary and discussion of the following articles, which in the introductory chapter are referred to by their Roman numerals:

I SALONEN, J. 1993. Weed infestation and factors affecting weed incidence in spring cereals in Finland - a multivariate approach. Agricultural Science in Finland 2: (in press).

II SALONEN, J. \& ERVIÖ, L.-R. 1988. Efficacy of chemical weed control in spring cereals in Finland. Weed Research 28: 231-235.

III SALONEN, J. 1992. Efficacy of reduced herbicide doses in spring cereals of different competitive ability. Weed Research 32: 483-491.

IV SALONEN, J. 1992. Yield responses of spring cereals to reduced herbicide doses. Weed Research 32: 493-499.

V SAlonen, J. 1993. Performance of reduced herbicide doses in spring cereals. Agricultural Science in Finland 2: (in press).

Reprints of the original articles II-IV are published with the kind permission of Blackwell Scientific Publications. 


\section{CONTENTS}

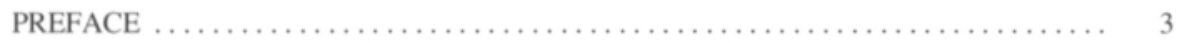

LIST OF ORIGINAL ARTICLES $\ldots \ldots \ldots \ldots \ldots \ldots \ldots \ldots \ldots \ldots \ldots \ldots \ldots \ldots \ldots \ldots$

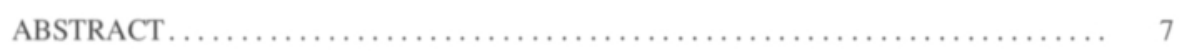

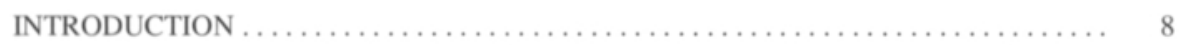

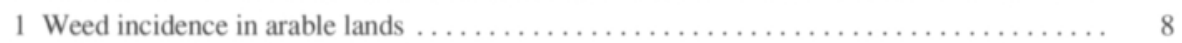

1.1 Species composition of weed floras $\ldots \ldots \ldots \ldots \ldots \ldots \ldots \ldots \ldots \ldots \ldots \ldots$

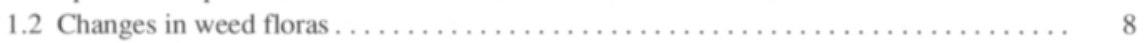

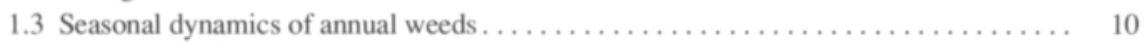

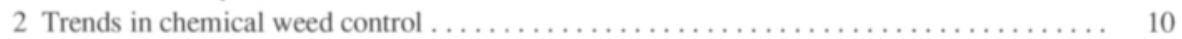

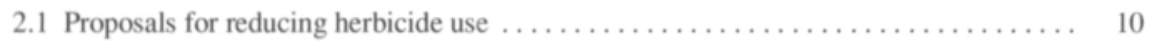

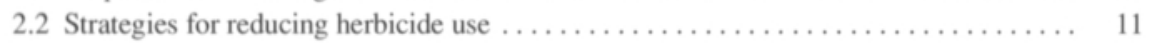

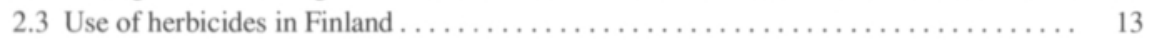

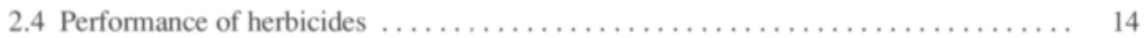

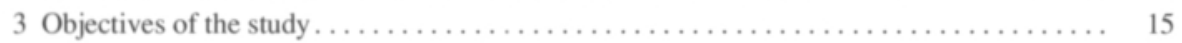

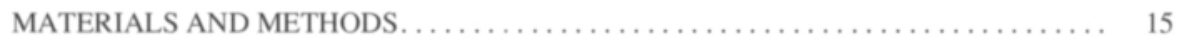

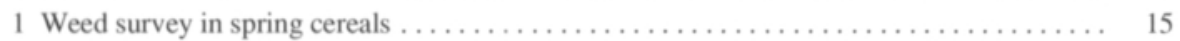

2 Dose reduction of herbicides in field experiments $\ldots \ldots \ldots \ldots \ldots \ldots \ldots \ldots \ldots \ldots \ldots$

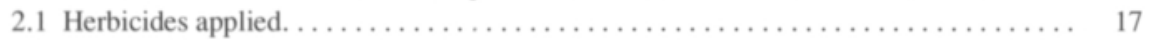

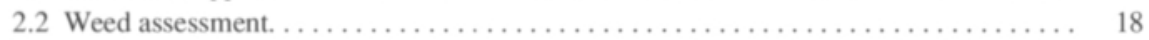

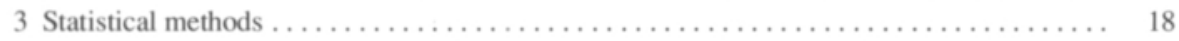

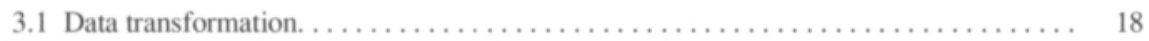

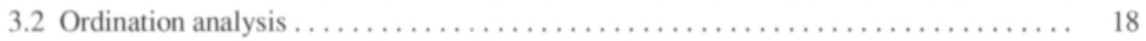

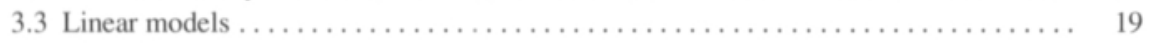

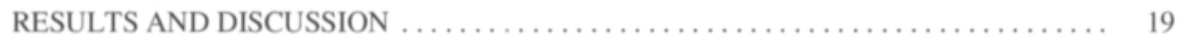

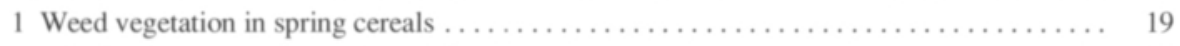

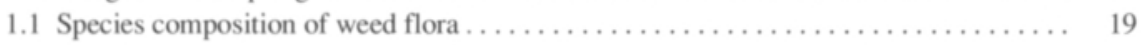

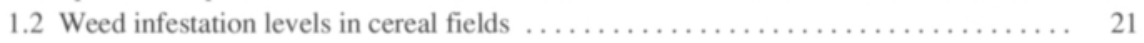

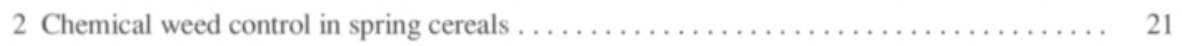

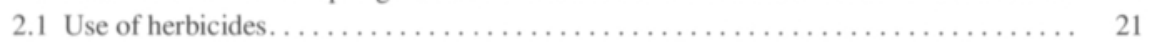

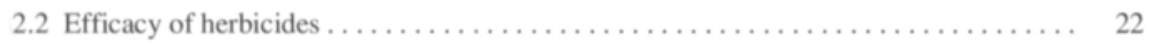

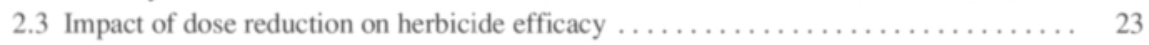

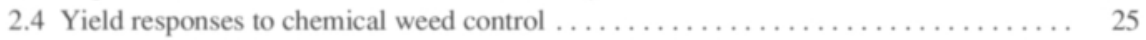

2.5 Basing the herbicide use on crop-weed interactions. . . . . . . . . . . . . . 26

2.6 Impact of herbicides and crop rotation on weed infestation $\ldots \ldots \ldots \ldots \ldots \ldots \ldots \ldots$

3 Economic impact and practical implications of herbicide dose reduction. . . . . . . 30

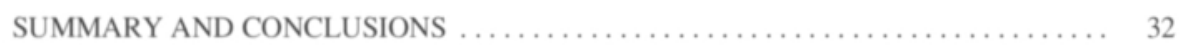

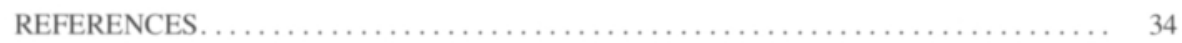

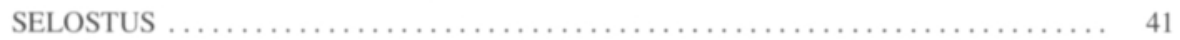





\title{
Reducing herbicide use in spring cereal production
}

\author{
JUKKa SALONEN
}

SAlonen, J. 1993. Reducing herbicide use in spring cereal production. Agric. Sci. Finl. 2: Supplement No. 2. 42 p. Academic dissertation. (Agric. Res. Centre of Finland, Inst. Plant Protect., FIN-31600 Jokioinen, Finland.)

A survey was conducted in southern and central Finland from 1982 to 1984 to determine the main weed species affecting spring cereal production. The weed flora was dominated by broad-leaved species. The most common broad-leaved weeds were Chenopodium album L., Galeopsis L. spp., Viola arvensis Murr. and Stellaria media (L.) Vill., and the most common grass weed was Elymus repens (L.) Gould. The density of weeds averaged 170 plants $\mathrm{m}^{-2}$ (median 124), and the dry weight $320 \mathrm{~kg} \mathrm{ha}^{-1}$ (median 183). Ordination analyses revealed that the species composition of weed populations varied regionally and was affected by soil characteristics and crop management practices, particularly by long-term use of herbicides.

An additional aspect studied in the survey was herbicide efficacy in farmers' fields. Phenoxy acid herbicides, MCPA, dichlorprop and mecoprop, were the most common active ingredients used in the 252 spring cereal fields surveyed. MCPA alone gave only a moderate control of $65 \%$, determined as a reduction of weed biomass, whereas the efficacy of herbicide mixtures containing MCPA averaged $83 \%$. Inadequate control was in most cases due to a wrong choice of active ingredient for the prevailing weed population.

Reduction in the use of herbicides by applying lower doses than recommended was studied in field experiments. Herbicide formulations of MCPA/dichlorprop, MCPA/ mecoprop and MCPA/fluroxypyr were screened in spring barley (Hordeum vulgare L.) and spring wheat (Triticum aestivum L.) fields. The efficacy of herbicides, applied at the lowest recommended dose, averaged $85 \%$. At a $30 \%$ lower dose the efficacy still reached $79 \%$. Even lower herbicide doses were often adequate, depending on the herbicide, weed species and the crop. The production of weed biomass was adequately suppressed with reduced doses since the most common and aggressive species, such as Chenopodium album and Galeopsis spp., were efficiently controlled with low doses. Use of reduced herbicide doses for three years in the same field caused neither an increase in the subsequent weed infestation nor changes in the species composition of weed populations compared with the treatments at recommended rates of application.

The percentage emergence of weeds averaged $70-75 \%$ at the time of herbicide application when the crop was at the 3-4 leaf growth stage. However, spraying during the early growth stages of those weeds that emerge in the main flush is recommended since the competitive ability of the crop is normally sufficient to suppress the growth of late-emerging weed seedlings. At harvest the proportion of weed biomass in unsprayed plots, as a proportion of the total vegetative biomass, averaged $3.1 \%$ in barley fields and $3.6 \%$ in wheat fields. The growth of weeds was more efficiently suppressed with reduced herbicide doses than by increasing the seeding rate of the crop. The mean yield gain remained below $5 \%$ at all rates of herbicide application.

No reliable density-based threshold for chemical weed control was established. Instead, site-specific dose adjustment based on the composition and infestation level of the prevailing weed populations is suggested to reduce the total use of herbicides and to maintain the current low levels of weed infestation. Consequently, annual reductions of $30 \%$ in use of cereal herbicides are expected. Such a reduction corresponds to monetary savings of approximately FIM 20 million per annum at the national level.

Key words: spring barley, spring wheat, broad-leaved weeds, weed survey, efficacy of herbicides, reduced doses of herbicides, yield response, CCA, CANOCO 


\section{INTRODUCTION}

Optimization of crop protection measures requires adequate information on pests and weeds. Identification of the principal weed species and awareness of their population dynamics and impact on crop production are key factors for successful weed control. Furthermore, adjustment of control measures according to the prevailing weed infestation is a prerequisite for economic and sustainable crop production. The optimization of herbicide use can be defined as a reduction in the level of active ingredient used to the minimum necessary to meet a defined need (CUSSANS 1992). Appraisal of the rational use of herbicides in spring cereal production in Finland is given in this study.

\section{Weed incidence in arable lands}

\subsection{Species composition of weed floras}

Worldwide, about 200 species of the 250,000 plant species are classified as important weeds (HoLM et al. 1977). A comprehensive review of the factors influencing the distribution of weeds in Europe is given by HolzNER and IMMONEN (1982). They reported that the most significant alterations in weed communities have taken place since 1950 . HAAS and STREIBIG (1982) gave a detailed description of changing patterns of weed distribution in Denmark. They concluded that although herbicides evidently have been one of the major driving forces in changing the species composition and infestation level of weed populations, several other factors included in crop production, such as crop rotation, fertilization etc., have also affected weed floras.

Several studies on weed floras of arable lands in the Nordic countries have been published (Table 1). Considerable similarities in the species composition of weed floras in the different countries is evident from these studies. About 50 weed species are common and of economic importance in the Nordic countries. The most frequently occurring broad-leaved weeds are Chenopodium album L.,
Polygonum L. spp., Stellaria media (L.) VILL., Viola arvensis MURR., and the most important grass weed is Elymus repens (L.) GOULD.

ERVIÖ and SALONEN (1987) compared the weed populations of the 1960s and the 1980s in spring cereal fields in Finland. They found a slight decline in the frequency of $C$. album, Galeopsis L. spp., $S$. media, Erysimum cheiranthoides L., Myosotis L. spp., Spergula arvensis L. and Tripleurospermum inodorum SHULTZ BIP.. Weed species that were found more frequently in the 1980 s were e.g. $V$. arvensis, Fallopia convolvulus (L.) Á. LÖVE, Lapsana communis L., Polygonum aviculare L., Fumaria officinalis L., Galium L. spp., Lamium L. spp. and Matricaria matricarioides (LESS.) PORTER. Among the 15 most frequently occurring weed species, ten were tolerant of MCPA, in comparison with nine in the 1960s (MUKULA et al. 1969).

In general, manipulation of the environment for agricultural purposes has favoured species that can adapt to the disturbed habitats of cultivated fields, whereas sensitive species have become extinct (Young and Evans 1976, EgGERS 1984). The impact of intensive agricultural practices on weed floras has reached the stage where even the conservation of endangered weed species has been suggested (EGGERS 1987, WILSON et al. 1990, MAHN 1992).

\subsection{Changes in weed floras}

The occurrence of weeds and the changes in weed floras are often related to crop management (e.g. BACHTHALER 1969, RADEMACHER et al. 1970, Cussans et al. 1979, HaAs and Streibig 1982, Froud-Williams et al. 1983, Post 1986). Crop management in Finland, as in Europe generally, has been intensified enormously in recent decades resulting in well-established crop stands and a trend of increasing yields per unit area (MUKULA and RANTANEN 1987). The use of herbicides and inorganic fertilizers have been adopted in modern cereal production, and crop rotations have changed 
Table 1. Studies on weed floras of arable lands in the Nordic countries.

\begin{tabular}{|c|c|c|c|c|c|c|c|c|}
\hline \multirow{2}{*}{$\begin{array}{l}\text { Country } \\
\text { Finland }\end{array}$} & \multirow{2}{*}{$\frac{\text { Study }{ }^{1}}{\text { I }}$} & \multirow{2}{*}{$\begin{array}{l}\text { Crop } \\
\text { Cereals }\end{array}$} & \multicolumn{5}{|c|}{ Most common weed species ${ }^{2}$} & \multirow{2}{*}{$\begin{array}{l}\text { Reference } \\
\text { HILLLI } 1948\end{array}$} \\
\hline & & & GAESS & CHEAL & RAPRA & SPEAR & AGRRE & \\
\hline & $\mathrm{S}$ & Grassland & DECCA & TAROF & RUMSS & AGRRE & CHYLE & PAATELA 1953 \\
\hline & $\mathrm{S}$ & Spring cereals & GAESS & CHEAL & SPEAR & STEME & VIOAR & MuKULA et al. 1969 \\
\hline & $\mathrm{S}$ & Grassland & RANRE & ACHMI & RUMSS & TAROF & DECCA & $\begin{array}{l}\text { RAATIKAINEN and } \\
\text { RAATIKAINEN } 1975\end{array}$ \\
\hline & $\mathrm{S}$ & Winter cereals & VIOAR & CHEAL & GAESS & MATSS & ERYCH & RAATIKAINEN et al. 1978 \\
\hline & $\mathrm{S}$ & Spring cereals & CHEAL & GAESS & VIOAR & STEME & POLCO & ERVIÖ and SALONEN 1987 \\
\hline \multirow[t]{4}{*}{ Denmark } & $\mathrm{S}$ & Winter rye & STEME & POAAN & CHEAL & VIOAR & MYOAR & Petersen 1943 \\
\hline & $\mathrm{S}$ & Cereals & STEME & VIOAR & POLCO & POAAN & PLAMA & MIKKELSEN and LAURSEN 1966 \\
\hline & $\mathrm{S}$ & Spring barley & STEME & VIOAR & POAAN & CHEAL & MYOAR & ANDREASEN et al. 1989 \\
\hline & $\mathrm{S}$ & Grassland & POAAN & STEME & TARSS & CAPBP & VERSS & ANDREASEN 1990 \\
\hline \multirow[t]{3}{*}{ Norway } & $\mathbf{R}$ & Arable land & \multicolumn{5}{|c|}{ General review on the main species } & KORSMO 1925 \\
\hline & $\mathrm{F}$ & Spring cereals & CHEAL & STEME & GAESS & VIOAR & LAMPU & FYKSE 1993 (pers. commun.) \\
\hline & $\mathrm{F}$ & Grassland & RUMLO & RANAC & TAROF & RANRE & RUMAC & FYKSE 1993 (pers. commun.) \\
\hline \multirow[t]{6}{*}{ Sweden } & $\mathrm{S}$ & Spring cereals & CHEAL & GAESS & SPEAR & STEME & POLLA & Granstróm and AlmgÁRD 1955 \\
\hline & $\mathrm{S}$ & Winter cereals & MATMA & PAPSS & CENCY & STEME & LAMSS & GRANSTRÖM and AlmgÁRD 1955 \\
\hline & $\mathrm{F}$ & Spring cereals & CHEAL & GAESS & STEME & POLSS & SPEAR & GUMMESSON 1975 \\
\hline & $\mathrm{F}$ & Winter cereals & MATMA & STEME & VIOAR & VERSS & GALSS & GUMMESSON 1975 \\
\hline & $\mathrm{F}$ & Spring cereals & CHEAL & STEME & GAESS & VIOAR & MYOAR & HALLGREN 1993a \\
\hline & $\mathrm{F}$ & Winter cereals & STEME & VIOAR & MATMA & MYOAR & VERSS & HALLGREN 1993a \\
\hline
\end{tabular}

1 Type of study: $\mathrm{F}=$ Field trials, $\mathrm{I}=$ Inquiry, $\mathrm{R}=$ Review, $\mathrm{S}=$ Survey

2 Codes according to BAYER (1992): ACHMI = Achillea millefolium, AGRRE $=$ Elymus repens, CAPBP $=$ Capsella bursapastoris, $\mathrm{CENCY}=$ Centaurea cyanus, CHEAL = Chenopodium album, CHYLE = Chrysanthemum leucanthemum, DECCA = Deschampsia caespitosa, ERYCH = Erysimum cheiranthoides, GAESS = Galeopsis spp., GALSS = Galium spp., LAMPU = Lamium purpureum, LAMSS = Lamium spp., MATMA = Matricaria matricarioides, MATSS = Matricaria spp., MYOAR = Myosotis arvensis, PAPSS = Papaver spp., PLAMA $=$ Plantago major, $\mathrm{POLCO}=$ Fallopia convolvulus, POLLA $=$ Polygonum lapathifolium, POLSS $=$ Polygonum spp., POAAN $=$ Poa annua, RANAC $=$ Ranunculus acris, RANRE = Ranunculus repens, RAPRA $=$ Raphanus raphanistrum, $\mathrm{RUMAC}=$ Rumex acetosa, $\mathrm{RUMLO}$ $=$ Rumex longifolius, RUMSS $=$ Rumex spp., SPEAR $=$ Spergula arvensis, STEME $=$ Stellaria media, $\mathrm{TAROF}=$ Taraxacum vulgare, TARSS = Taraxacum spp., VERSS $=$ Veronica spp., VIOAR $=$ Viola arvensis

considerably over time, often tending towards monoculture. These changes have caused both quantitative and qualitative changes in weed populations (FrYer and CHANCELlOR 1970, RADEMACHER and KOCH 1972, REUSS 1981, MAHN 1984).

The most apparent change in weed populations in recent decades has been the decline in weed abundance $\left(\right.$ No. $\mathrm{m}^{-2}$ ) in cereal fields (AAMISEPP and WALLGREN 1979, ERVIÖ and SALONEN 1987, HALlgren 1993a). ERVIÖ and SALONEN (1987) reported that the density and biomass production of weeds in Finnish spring cereal fields have de- creased to about one-third of the values recorded during the 1960s. Furthermore, the number of weed species has decreased in intensive cropping systems (Fogelfors 1979, Callauch 1981, Albrecht and Bachthaler 1988, Debaeke 1990, SPERANZA et al. 1990).

Changes in weed vegetation are not only restricted to alterations in species composition and their proportional abundance (interspecific), but also to changes within the population of one species (intraspecific). A good example of the intraspecific variability of weeds is resistance of a weed population to a herbicide as a result of its continuous 
application promoting selection in the weed population (LEBARON and GRESSEL 1982). Generally, a number of selective factors including light regime, soil type, biotic factors and agricultural practices, result in genetic differentiation in weed populations (WARWICK 1991).

\subsection{Seasonal dynamics of annual weeds}

Variation in the emergence of weeds between seasons and within one growing season are characteristic to weed populations (ROBERTS and POTTER 1980, ERVIÖ 1981, HÅKANSSON 1983a, ANDREASEN 1990). The timing of sowing and growth period of crops are important factors determining the composition and abundance of weed populations (Streibig and HaAs 1979, ChanCELlOR 1985). Annual weed species can roughly be divided into three categories according to their germination patterns (HÅKANSSON 1992):

A. Summer annuals with a germination peak in spring, decreasing towards the end of the growing season. Typical species: Chenopodium album, Fumaria officinalis, Galeopsis spp., Polygonum aviculare.

B. Facultative winter annuals with extensive germination both in the spring and, after soil tillage, in late summer to early autumn. Typical species: Lamium spp., Myosotis arvensis, Stellaria media, Tripleurospermum inodorum, Viola arvensis.

C. Other species. Summer annuals or mainly summer annual behaviour, but with extensive germination both in the spring, after soil tillage, and also later in the growing season. Typical species: Brassica L. spp. (also cultivated forms), Spergula arvensis.

The time of weed emergence affects the success of chemical control, as the most common postemergence herbicides used in cereal production are foliar-active, with minor effect on the weed seedlings emerging after herbicide application.

\section{Trends in chemical weed control}

\subsection{Proposals for reducing herbicide use}

The principles of weed control have been comprehensively documented (e.g. HANCE and HOLLY 1990). It has been frequently shown that the judicious use of herbicides is characteristic of successful and economic crop production (ZEDDIES 1986, BEYER 1991). Herbicides are commonly used in cereal production, although yield benefits from chemical weed control are sometimes questionable (GEROWITT et al. 1984, JENSEN 1985, DAVIES et al. 1989, ERVIÖ et al. 1991).

However, increase in cereal yield is not the only argument favouring the use of herbicides. It has been shown that chemical weed control also $i$ ) prevents weeds from interfering with cultivation, harvesting and marketing (ELLIOTT 1978), ii) reduces the number of host plants of pathogens and pests (HEITEFUSS 1986) and iii) reduces the reservoir of weed seeds in the soil (HURLE 1974, KEES 1986, FYKSE 1991a). In contrast to the negative aspects of weed interference, HEITEFUSS (1986) has reviewed also the benefits of weeds, including a positive effect on soil structure and soil humus, and moreover on the incidence of a beneficial fauna.

Although several alternatives to herbicides, including biological, mechanical and physical control are available (EDWARDS and REGNIER 1989, MORGAN 1992, WATSON 1992), herbicides will probably maintain their major role in weed control. However, it has been widely recognised that weed control strategies in the future are likely to require an integration of non-chemical techniques with more efficient, but restricted, use of herbicides (COMBellaCK 1992a, Cussans 1992).

In the 1980s, the Nordic countries introduced political Action Plans, which stipulate considerable reductions in the use of pesticides (THONKE 1991). A common aim is to reduce the amount of applied active ingredients (a.i.) of pesticides by $50 \%$ of the average amount used in the early 1980 s. This policy has been adopted in Denmark (THONKE 1991) and in Sweden (BERNSON 1988), as well as in the Netherlands (Ministry of Agriculture 1990). In 
Norway the aim is to reduce pesticide use "as much as reasonable" (STUBSJøEN 1991).

A recently published committee proposal (Ympäristöministeriö 1992) quantified the political expectations on the reduction of pesticide use in Finland. The target is to halve the average use of 2,000 tons a.i. (1987-1991) before 1995. Strategies proposed and the estimated reduction with each approach were:

1) changes in crop production and land usage (1520\%)

2) use of pesticides according to the defined need (10-15\%)

$3)$ tests and repairs of spraying equipment (10$15 \%)$

4) alternative control methods (15\%)

A co-operative effort on behalf of those involved in crop production practices, the extension services and research has to be made to meet the abovementioned political targets. Sales statistics indicate that a desirable trend has already started (Fig. 1). Reduction in herbicide use can partly be explained by the changes in agriculture, including increased area of fallows, a more rational use of herbicides, and a shift to low-dose herbicide products.

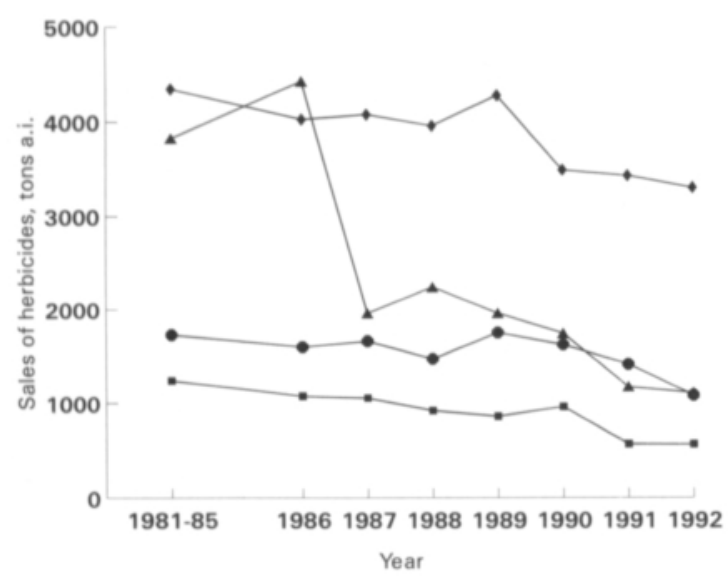

Fig. 1. Sales of herbicides in the Nordic countries. The average amount of active ingredients (tons a.i.) in 1981-1985 and the sales in 1986-1992 in Denmark $(\bullet)$, Sweden $(\boldsymbol{\Delta})$, Finland (-) and Norway (ם). Data compiled from ThonkE (1991), from the National Board of Agriculture in Finland, from the Kemikalieinspektionen in Sweden and from Denmark (Flakkebjerg) and to Norway (Statens Plantevern) via personal communications .
Possibilities for reducing the recommended doses of phenoxy acid herbicides by $25 \%$, without a considerable loss in efficacy, were reported already twenty years ago (HORNIG 1972). Within the range of $25-50 \%$ reduction of herbicide dose, a similar trend was observed also in field experiments carried out in Denmark in the 1970s (THONKE 1978). Consequently, intensive research efforts in the Nordic countries were launched to optimize the use of herbicides in crop production, particularly in cereals (AAMISEPP 1984, ANDERSSON 1984, 1986, ERVIÖ and HiIVOLA 1986, THONKE 1986, KUDSK 1989, FogELFORS 1990, LOMAKKA 1990).

\subsection{Strategies for reducing herbicide use}

Appraisal of the need for reduced weed control is often based on the apparent decline in weed infestation levels. However, weeds vary considerably in distribution in place and time (MARSHALL 1988, WILSON and BRAIN 1990). Complexities resulting from spatial heterogeneity and the multi-species nature of weed communities make modelling of the crop-weed interactions difficult and hamper decisions on chemical weed control (AULD and TISDELl 1988, VAN Groenendael 1988, KropfF 1988, THORNTON et al. 1990).

Routine use of herbicides has been a common approach to overcome the problems of determining the necessity for chemical control, often to such extent that cost-benefit considerations have been forgotten. Two different approaches, $i$ ) prophylactic and ii) threshold strategies, have been studied in an attempt to change the present control practices (Table 2).

GUMMESSON and FOGELFORS (1990) suggested that the annual use of herbicides should be decreased by applying reduced herbicide doses and not by reducing the treated land area. On the other hand, the threshold approach, whether to spray or not, has been widely studied and applied, particularly in Germany, mainly in winter cereals (GARBURG 1974, HeITEFUSS et al. 1987, GEROWITT and HEITEFUSS 1990, WAHMHOFF 1990), but also in 
Table 2. Two diverse strategies to reduce herbicide use in cereal production. Appraisals of a) threshold weed infestations to withhold herbicide application and b) the levels of reduction of the recommended herbicide doses.

a)

\begin{tabular}{|c|c|c|c|}
\hline Country & Crop & $\begin{array}{c}\text { Threshold } \\
\text { (weeds } \mathrm{m}^{-2}, \% \text { cover) }\end{array}$ & Reference \\
\hline \multirow[t]{4}{*}{ Germany } & Spring barley & 87 & GARBURG 1974 \\
\hline & Spring wheat & 50 & \\
\hline & Winter wheat & 26 & \\
\hline & Winter cereals & $\begin{array}{r}20-30 \text { (monocots) } \\
40-50 \text { (dicots) }\end{array}$ & Gerowitt and Heitefuss 1990 \\
\hline \multirow[t]{2}{*}{ Denmark } & Spring barley & $80-100$ & Streibig 1983 \\
\hline & Spring barley & $20-50$ & JENSEN 1987 \\
\hline Norway & Spring barley & 175 & FYKSE 1991b \\
\hline U.K. & Spring barley & 150 & COURTNEY and JOHNSTON 1986 \\
\hline Finland & Spring cereals & $52-101$ & ERvio et al. 1991 \\
\hline \multirow[t]{2}{*}{ Germany } & Winter wheat & $6.7-9.7 \%$ & BEER 1979 \\
\hline & Winter barley & $6.1-18.7 \%$ & \\
\hline Austria & Cereals & $3.2-9.3 \%$ & Neururer 1976 \\
\hline
\end{tabular}

b)

\begin{tabular}{llrl}
\hline Country & Crop & \multicolumn{1}{c}{$\begin{array}{c}\text { Reduction of } \\
\text { herbicide dose, \% }\end{array}$} & Reference \\
\hline Germany & Spring barley & $25-50$ & HorNIG 1972 \\
Denmark & Spring barley & $25-50$ & PEDERSEN 1978 \\
Sweden & Spring cereals & $33-67$ & ENGSTROM 1978 \\
& Spring cereals & $33-67$ & AAMISEPP 1984 \\
& Spring barley & $33-67$ & LoMAKKA 1990 \\
Finland & Cereals & $50-75$ & FoGELFORS 1990 \\
U.K. & Spring cereals & 50 & ERVIO and HıVOLA 1986 \\
\hline
\end{tabular}

spring cereals (e.g. FYKSE 1991a, DAvIES et. al 1993).

GEROWITT and HEITEFUSS (1990) used the fixed threshold values of $20-30$ plants $\mathrm{m}^{-2}$ for grass weeds, and 40-50 plants $\mathrm{m}^{-2}$ for broad-leaved weeds, in winter cereals. In addition, some specific weed species such as Galium aparine L. (0.1-0.5 plants $\mathrm{m}^{-2}$ ) and Fallopia convolvulus (2.0 plants $\mathrm{m}^{-2}$ ) were considered very harmful and a substantially lower threshold was suggested. CUSSANS (1980) ranked the population densities of weeds on a logarithmic scale (Table 3) for strategic planning of weed control measures. In general, the influence of crop type and differences between weed species are emphasized in the threshold approach. Threshold values can be based either on biological or economical considerations, as discussed by CuSSANS et al. (1986).

A more sophisticated approach, to define the effect of weed competition on yield loss, was introduced by WILSON (1986): different weed species were given a Crop Equivalent (CE) value based on 
Table 3. Some definitions of weed densities by Cussans (1980).

\begin{tabular}{lll}
\hline $\begin{array}{l}\text { Population } \\
\left(\text { weeds } \mathrm{m}^{-2}\right)\end{array}$ & $\begin{array}{l}\text { Short } \\
\text { description }\end{array}$ & $\begin{array}{l}\text { Notes - with special } \\
\text { reference to cereals }\end{array}$ \\
\hline$>100$ & Very severe & $\begin{array}{l}\text { Certain to cause yield loss } \\
\text { Yield loss usually greater } \\
\text { than the cost of spraying }\end{array}$ \\
$10-100$ & Severe & $\begin{array}{l}\text { Some competition inter- } \\
\text { ference probable }\end{array}$ \\
$0.1-1$ & Moderate & $\begin{array}{l}\text { Not competitive in many } \\
\text { crops but an obvious } \\
\text { latent threat }\end{array}$ \\
$0.01-0.1$ & Light & $\begin{array}{l}\text { Very unlikely to have a } \\
\text { measurable effect on yield }\end{array}$ \\
$0.001-0.01$ & Very light & $\begin{array}{l}\text { No effect on yield or } \\
\text { quality }\end{array}$ \\
$0.0001-0.001$ & Economically & $\begin{array}{l}\text { Very easily rogued by } \\
\text { hand }\end{array}$ \\
\hline
\end{tabular}

dry weight per weed divided by dry weight per crop plant, assessed from extensive field data. A threshold value of 5 CEs was suggested as a Spray Decision threshold. DAVIES et al. (1993) compared this approach to routine use of halfdose application of herbicides and found that the threshold approach applied over some years was insufficient to keep the weed infestation at the original level. Moreover, the cost savings from using the threshold option were partly absorbed by the costs of assessing weed infestation before the decision-making.

ERVIÖ and HIIVOLA (1986) compared the threshold and prophylactic strategies in spring cereals in Finland. They found no differences in the subsequent weed populations whether a continuous or threshold application of herbicide was employed during the five-year study.

\subsection{Use of herbicides in Finland}

The era of chemical weed control started in Finland in the early 1960s, when the area of cereal fields treated with MCPA reached $30 \%$ and increased rapidly (MUKULA and RUUTTUNEN 1969). Since then MCPA has been the most common herbicide used in cereal production. In the 1960s and 1970s, MCPA alone made up over two-thirds of the total amount of all herbicides used in agriculture (MARKKULA et al. 1990).

At present, MCPA is most often used in formulated herbicide mixtures with dichlorprop or mecoprop (Fig. 2). Furthermore, introduction of novel low-dose herbicides such as sulfonylureas has resulted in decreased use of MCPA and other phenoxy acids. In the mid 1980 s, when we started the field experiments, the quantity of sulfonylureas sold in Finland was sufficient to treat approximately $10 \%$ of the cultivated cereal area, but increased to 26\% in 1992 (JUNNILA 1993). Thus, the phenoxy acid herbicides have still retained their major role in weed control in cereals in Finland. It is desirable, however, that herbicides with different mechanisms of action are available and used to avoid the selection of weed populations which may eventually become herbicide resistant (GRESSEL and SEGEL 1982).

Sales statistics of pesticides have been available since 1953; during the years 1953-1987 a total of 37,281 tons active ingredients (a.i.) of herbicides, accounting for $83 \%$ of pesticides, were applied in agricultural fields (MARKKULA et al. 1990). Herbicides are still the largest group of pesticides used in Finland. During 1990-1992 herbicides represented $76 \%$ of the total volume of active ingredients applied and $65 \%$ of the monetary value of pesticides overall (data compiled from HYNNINEN and BLOMQVIST 1991, 1992, 1993).

Herbicide sales peaked in 1980 with 2,099 tons of active ingredients sold that year (TIITTANEN and BLOMQVIST 1981). Annual use of agricultural herbicides during 1990-1992 averaged 1,320 tons a.i. per annum (HYNNINEN and BLOMQVIST 1991, 1992, 1993) representing a slightly declining trend in annual use (Fig. 2). The amount of herbicides sold in $1990-1992$ was sufficient to treat $69-75 \%$ of the area under cereal production during each year.

In recent years, overall, the use of herbicides has decreased mainly due to agricultural policy (e.g. set-aside fields) aiming at reducing overproduction of cereals. In addition to the indirect decline in herbicide use, a real decline in the use of phenoxy 


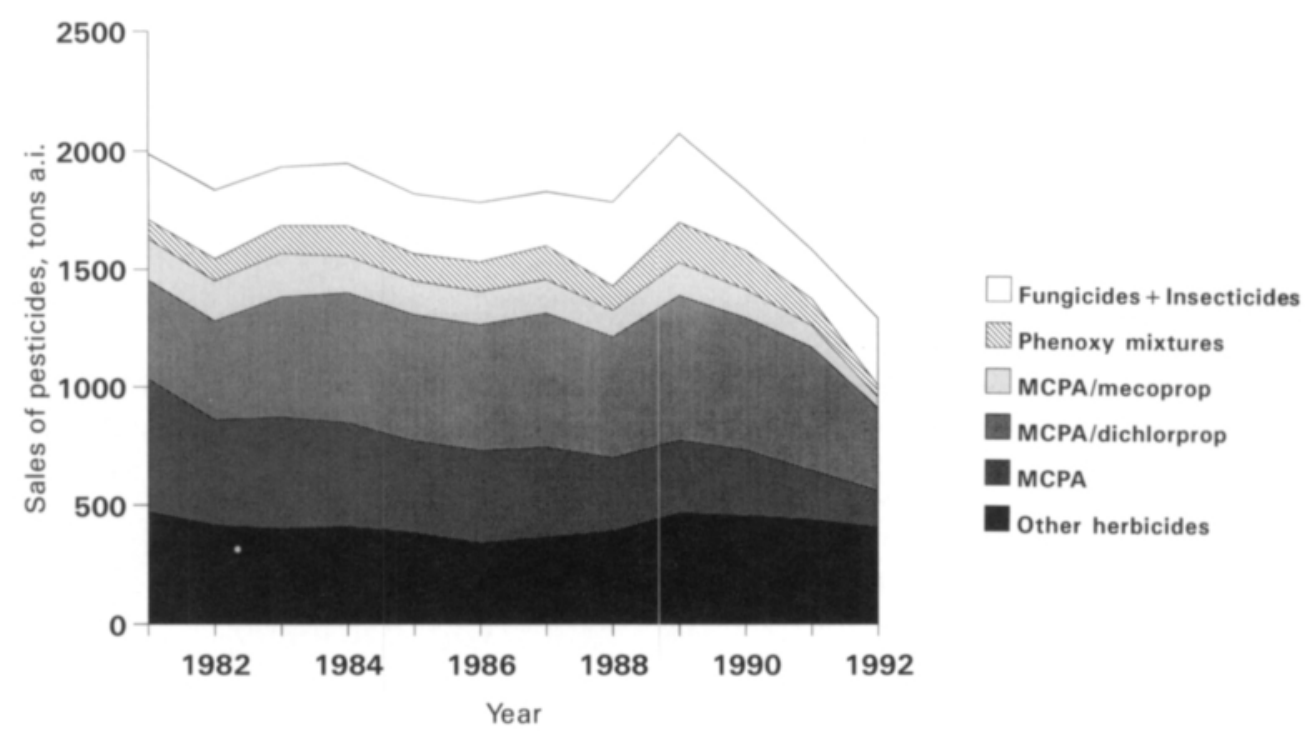

Fig. 2. Sales of pesticides in Finland since 1981. Data compiled from the statistics released annually by the National Board of Agriculture.

acids, in quantity of a.i., is expected following approval in Finland in 1992 of the new isomer formulations of dichlorprop and mecoprop. A shift from racemic formulations to these optically active isomers would correspond approximately to a $50 \%$ decrease in the use of active ingredients concerned.

\subsection{Performance of herbicides}

Herbicide doses should be adjusted to a level that is sufficent to control a range of target weeds without damaging the crop plant. The effect of herbicides against different weed species varies and results in selective control of weed populations. Therefore, herbicide mixtures are both manufactured and made by farmers for broad-spectrum weed control.

Phytotoxic effects of herbicides are normally assessed on a quantitative scale as a response of plant number, biomass, height etc. to the applied chemical, and often described relative to an untreated control. Analysis of variance is commonly applied to test treatment effects. However, the use of a dose-response curve, describing the whole dose range, from the no effect level to complete kill at high doses, is recommended for thorough herbicide bioassay (STREIBIG 1992). An S-shaped logistic curve fitted with non-linear regression analysis is considered appropriate to describe herbicide efficacy and to compare the relative potency of different herbicides (STREIBIG 1988).

Herbicide performance is affected by environmental conditions before, at, and after herbicide application (KUDSK and KRISTENSEN 1992). Despite numerous reports on herbicide-environment interactions, the mechanisms by which herbicide activity is influenced by different environmental factors is poorly understood (DEVINE 1988). Particular problems arise in extrapolating results from controlled conditions to the field. Consequently, inconsistent weed control with herbicides is a continuing problem.

Agrochemical companies, which are primarily responsible for the herbicide efficacy, attempt to minimize the risk of control failures by recommending application rates that are expected to be sufficient even under unfavourable conditions. However, from the farmers' economical point of view it is important to determine the potential for regulating the dose of herbicides according to the actual requirement. 


\section{Objectives of the study}

This study comprised investigations into the species composition of weed flora, the level of weed infestation and the efficacy of herbicides in spring cereal fields in Finland (I, II). Secondly, possibilities to reduce herbicide input by applying reduced herbicide doses were studied in field experiments (III, IV, V). The objective was to establish new recommendations for the use of herbicides in spring cereal production, taking into consideration the control efficacy, yield response and the impact on subsequent weed infestation levels.
The specific objectives were:

(1) to identify the most important weed species affecting spring cereal production in Finland,

(2) to validate the applicability of ordination analyses in describing the species composition of weed flora and in relating the occurrence of weeds to environmental factors

(3) to assess the efficacy of herbicides in farmers' fields

(4) to determine sufficient herbicide doses for effective weed control in spring cereal production

(5) to investigate the consequences of dose reduction of herbicides on efficacy, yield response and subsequent weed infestation.

\section{MATERIALS AND METHODS}

This study comprises three research projects conducted at the Agricultural Research Centre of Finland (ARC) during 1982-1992 (Fig. 3). PROJECT 1 was a national weed survey conducted in spring cereal fields in southern and central Finland in 1982-1984 (I, II). Based on the results of the weed survey, PROJECTS 2 and 3 were designed to study the possibilities of reducing the recommended doses of commonly applied phenoxy acid herbicides.

\section{Weed survey in spring cereals (I, II)}

The occurrence of weeds, the efficacy of herbicides and the economic returns from chemical weed control were investigated in 252 farmers' fields in southern and central Finland during 1982-1984 (see also ERVIÖ and SALONEN 1987). These fields comprised 155 fields studied in the 1960s by MUKULA et al. (1969) and 97 new fields. Results on the economics of weed control in the farm fields are reported elsewhere (ERVIÖ et al. 1991), as well as the comparison of the weed incidence in the 155 fields studied both in the 1960s and 1980s (SALONEN and ERVIÖ 1988). Basic facts about crop production in Finland are reviewed by MUKULA and RANTANEN (1987).

The study was restricted in advance to the 35 weed species ( 35 weed taxa) regarded as being the most important species according to the results of a previous survey (MUKULA et al. 1969), and according to information obtained from field experiments and the extension service. Two of the selected weed species, Senecio vulgaris L. and Solanum nigrum L., were absent from the 252 fields included in the analysis (I) thus resulting in a data set for 33 weed species.

Weed infestation was assessed in unsprayed and sprayed sample plots at the end of July, about one month after the application of herbicides. Information concerning crop management, soil characteristics and climatical conditions in the fields was either estimated, measured or obtained from the farmer (I).

\section{Dose reduction of herbicides in field experiments (III, IV, V)}

Field experiments with spring barley (Hordeum vulgare L.) and spring wheat (Triticum aestivum 


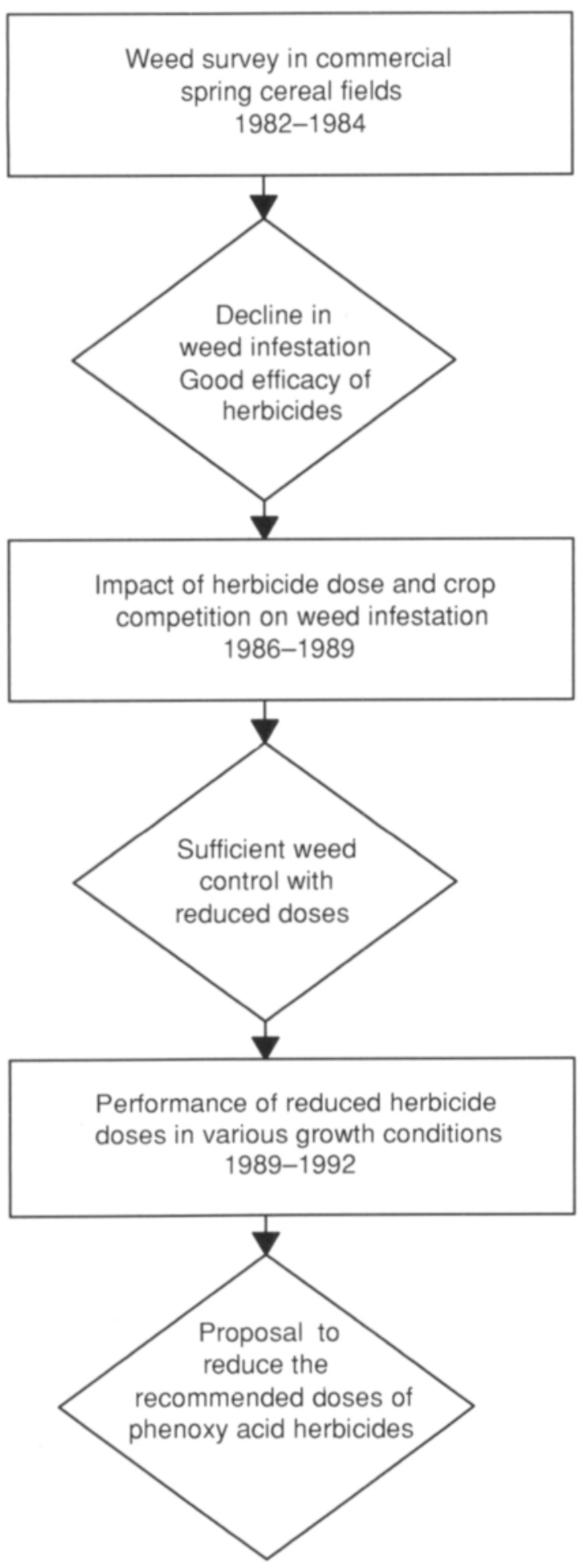

Fig. 3. A flow diagram of the research projects summarized in this study. A subject of the project $(\square)$ and the main outcome $(\diamond)$.

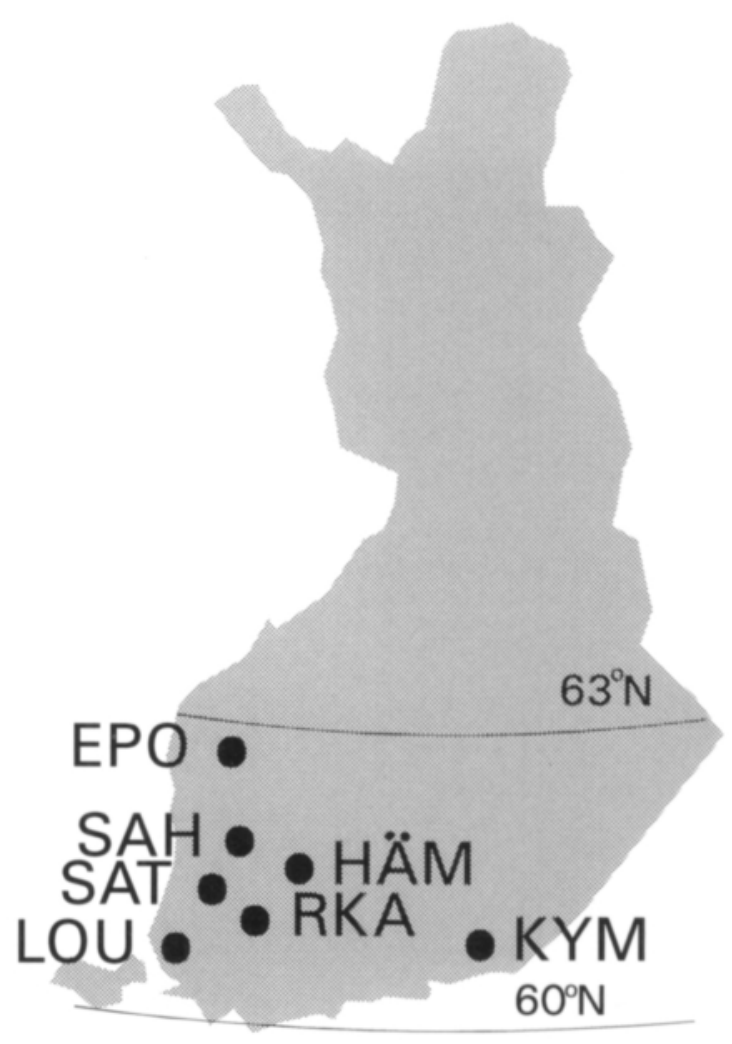

Fig. 4. Location of the regional research stations used for field experiments (III, IV, V). EPO = Ylistaro, HÄM = Pälkäne, $\mathrm{KYM}=$ Anjalankoski, $\mathrm{LOU}=$ Mietoinen, $\mathrm{RKA}=$ Jokioinen, SAH $=$ Mouhijärvi, SAT $=$ Kokemäki.

L.) were performed at the Agricultural Research Centre of Finland (ARC) in Jokioinen and at Ylistaro research station. Additionally, five other research stations of the ARC (Anjalankoski, Kokemäki, Mietoinen, Mouhijärvi and Pälkäne) in southern and central Finland were included in PROJECT 3 (V) (Fig. 4). Crop rotations in PROJECT 2 were barley-wheat-barley and wheat-barley-wheat, whereas barley or wheat were grown continuously for three years in PROJECT 3. The variety of spring barley was 'Arra' in PROJECT 2 and 'Pohto' in PROJECT 3. The varieties of spring wheat were 'Tapio' and 'Luja', respectively.

Field trials were laid out as randomized complete-block designs with four replicates. A splitplot arrangement of 140 plots per crop, with five 
Table 4. Summary of the herbicides screened in this study (III, IV, V). The rates of application recommended for spring cereals on the product label and the rates applied in the field experiments.

\begin{tabular}{|c|c|c|c|}
\hline \multirow[b]{2}{*}{ Active ingredients (a.i.) } & \multirow{2}{*}{$\begin{array}{l}\text { Study } \\
\text { Trade name }\end{array}$} & \multicolumn{2}{|c|}{ Herbicide dose, g a.i. ha-1 } \\
\hline & & recommended & applied \\
\hline & Reseach project 2 & & \\
\hline MCPA/fluroxypyr & Starane M & $400 / 100-600 / 150$ & $\begin{array}{r}200 / 50 \\
300 / 75 \\
600 / 150\end{array}$ \\
\hline \multirow[t]{2}{*}{ MCPA/mecoprop } & Herbotal Plus & $500 / 1000-800 / 1600$ & $\begin{array}{r}260 / 520 \\
400 / 800 \\
800 / 1600\end{array}$ \\
\hline & Research project 3 & & \\
\hline MCPA/fluroxypyr & Starane M & $400 / 100-600 / 150$ & $\begin{array}{r}280 / 70 \\
400 / 100\end{array}$ \\
\hline MCPA/dichlorprop-P & Duplosan DP-M & $451 / 485-716 / 770$ & $\begin{array}{l}331 / 356 \\
464 / 499\end{array}$ \\
\hline MCPA/mecoprop-P & Duplosan KV-M & $459 / 519-729 / 824$ & $\begin{array}{l}338 / 381 \\
473 / 534\end{array}$ \\
\hline Tribenuron-methyl & Express 75 DF & $6.0-9.75$ & 5.3 \\
\hline
\end{tabular}

crop seeding rates as the main plots, and herbicide treatments as the subplots, was used in PROJECT 2 (III, IV), and a randomized block arrangement of 24 plots in PROJECT 3. The plot size ranged from 30 to $48 \mathrm{~m}^{2}$ (3-4 $\left.\mathrm{m} \times 10-12 \mathrm{~m}\right)$ and the harvested area from 10 to $30 \mathrm{~m}^{2}$. The fields were ploughed every autumn to a depth of $20-25 \mathrm{~cm}$. The plots were cultivated in spring with tine harrow lengthwise of the plot to avoid the weed seed movement between the plots.

\subsection{Herbicides applied}

In the fields included in the weed survey (II) all decisions concerning weed control were made by the farmers, and herbicides were applied with their own tractor-mounted sprayers. Half of the observation areas $(1.8 \mathrm{~m} \mathrm{x} 2.4 \mathrm{~m})$ were covered with plastic film during herbicide application.

In the field experiments (III, IV, V), commonly used herbicide formulations of MCPA/dichlorprop and MCPA/mecoprop, a new candidate MCPA/ fluroxypyr and a reference herbicide tribenuronmethyl, were screened. Herbicides and their application rates (Table 4) were determined in advance, and not in relation to the prevailing weed infestation. Commercial herbicide mixtures were applied with portable van der Weij propane sprayers fitted with flat fan nozzles delivering $200 \mathrm{l} \mathrm{ha}^{-1}$ spray solution. Herbicides were applied at the 3- to 4-leaf stage of the crop (Zadoks' scale 13-15 (ZADOKS et al. 1974)).

In PROJECT 2 (III, IV), the efficacy of the highest recommended dose, and half and one-third of it were compared (Table 4). Results from PROJECT 2 (III, IV) contributed to the initiation of research PROJECT 3, in which the performance of the lowest recommended dose and a 30\% lower dose (Table 4), were evaluated in various fields and under various climatic conditions (V). Moreover, new formulations of phenoxypropionic herbicides, containing only the active isomers of dichlorprop and mecoprop, were introduced at that time (SQUIRES et al. 1987), and they were screened in PROJECT 3. 


\subsection{Weed assessment}

The emergence of weeds relative to growth stages of the crop was followed in research project $3(\mathrm{~V})$. The dates when the crop reached 1-, 2- and 3- leaf stages (stage 11, 12 and 13 on the Zadoks' scale) were recorded and the emergence time of weeds was related to the growth stages of the crop.

In all studies, the number and the above-ground biomass of weeds was assessed about 4 weeks after herbicide application. Additionally, in field experiments (III, IV, V), weed infestation was assessed 0-1 day before spraying, with some exceptions of 2 to 4 days delay, and also at harvest. Weed samples were collected from sample plots of $0.25 \mathrm{~m}^{2}$. Samples were taken to the laboratory, where the number and air-dry weight of weeds was recorded by species.

The long-term effect of continuous use of reduced herbicide doses was investigated by following the emergence of weeds from soil samples in a greenhouse (III) and by counting the number of weeds in the trial plots one year after the three-year trial period (V). Ten samples, $400 \mathrm{~cm}^{3}$ each, from the top $0-20 \mathrm{~cm}$ soil layer were taken for greenhouse tests from the plots sown at the recommended crop seeding rate. The soil samples were kept in pots for two growing seasons, and the number of emerging weed seedlings was recorded.

Scientific names of weed species (weed taxa) are according to the systematics used by HÄMET-AHTI et al. (1984). BAYER codes for weeds (BAYER 1992) were used in the introductory chapter and in Chapter I. In the other original articles weed codes were adapted from scientific names but not according to the BAYER standard.

\section{Statistical methods}

\subsection{Data transformation}

To define the structure of weed data, the descriptive statistical methods of the UNIVARIATE procedure in the SAS statistical programme package (SAS Institute Inc. 1985) were used. In particular, the need and effect of data transformation were assessed to give homogeneity of variances and normal distribution. Consequently, weed density data were square root transformed and weed biomass data logarithm transformed. The efficacy values (\% scale) were transformed with arcsine $(\sqrt{y})$.

\subsection{Ordination analysis}

The weed survey data (I) were subjected to ordination analyses (GAUCH 1982, JONGMAN et al. 1987) with the CANOCO program package (TER BRAAK 1987a). In recent years great attention has been paid to the application of constrained ordination techniques (BIRKS and AUSTIN 1992). Constrained ordination incorporates the features of indirect ordination methods and regression analysis to relate the species data to explanatory environmental variables. Ordination analyses were used to get a community level description of weed flora in Finnish spring cereal fields which was not possible with the regression techniques (ERVIÖ and SALONEN 1987).

The development of Canonical Correspondence Analysis (CCA) by TER BRAAK (1986) and its implementation in the computer program CANOCO encourages the application of ordination analyses, also in weed science. CCA is an extension of the eigenvector technique termed Reciprocal Averaging or Correspondence Analysis (CA) (HILL 1973, HILL and GAUCH 1980). The CA procedure ordinates the species data only, whereas in CCA the ordination axes are constrained to linear combinations of environmental variables introduced into a simultaneous analysis with species data. The response model fitted by CA and CCA for the species is a unimodal bell-shaped Gaussian curve (TER BRAAK 1987b):

$$
\mathrm{E}\left(\mathrm{y}_{\mathrm{ik}}\right)=\mathrm{c}_{\mathrm{k}} \exp \left[-1 / 2\left(\mathrm{x}_{\mathrm{i}}-\mathrm{u}_{\mathrm{k}}\right)^{2} / \mathrm{t}_{\mathrm{k}}{ }^{2}\right]
$$

where $\mathrm{E}\left(\mathrm{y}_{\mathrm{ik}}\right)$ denotes the expected value of species $\mathrm{k}$ at site $\mathrm{i}$,

$\mathrm{x}_{\mathrm{i}}$, the value of environmental variable $\mathrm{x}$ at site $\mathrm{i}$, $\mathrm{c}_{\mathrm{k}}$, the maximum value of the curve for species $\mathrm{k}$, $u_{k}$, the optimum value of species $k$ (value of $x$ ), $t_{k}$, the tolerance of species $k$ (curve breadth). 
A data set for 33 weed species and 12 environmental variables collected from 252 spring cereal fields was analysed with the CANOCO program (I). The significance of species-environment relationships was tested with a Monte Carlo permutation test. Ordination results were presented as species-environment biplots drawn with the CANODRAW program (ŠMILAUER 1990).

\subsection{Linear models}

Results from field trials were analyzed either (i) according to a standard multiple linear regression model or (ii) by basing the analyses on appropriate mixed models. Fixed effects of herbicide treatments were analyzed using crop densities as covariates in PROJECT 2. A different approach was used in PROJECT $3(\mathrm{~V})$, in which data with repeated measurements from the trial plots over three years, were analyzed in a fashion of split-plot experiment by using the following mixed model

$$
\begin{aligned}
& y_{i j k l}=\mu+\alpha{ }_{i}+\varphi l(i)+\beta_{j}+\alpha \beta_{i j}+\beta \varphi_{j l}(i)+\gamma_{k}+\alpha \gamma_{i k} \\
& +\gamma \varphi_{k l}(i)+\beta \gamma_{j k}+\alpha \beta \gamma_{i j k}+\varepsilon_{i j k l}
\end{aligned}
$$

where,

$\mathrm{y}_{\mathrm{ijkl}}$ is the observed response value,

$\mu \quad$ is the overall mean of sample population,

$\alpha_{\mathrm{i}}$ is the fixed effect of the trial site,

$\varphi \mathrm{I}(\mathrm{i})$ is the random effect of the block nested to a site,

$\beta_{\mathrm{j}}$ is the fixed effect treatment,

$\gamma_{\mathrm{k}}$ is the fixed effect of the year,

$\alpha \beta_{\mathrm{ij}}, \alpha \gamma_{\mathrm{ik}}, \beta \gamma_{\mathrm{jk}}, \alpha \beta \gamma_{\mathrm{ijk}}$ are the fixed interaction terms,

$\beta \varphi_{\mathrm{jl}(\mathrm{i})}, \gamma \varphi_{\mathrm{kl}(\mathrm{i})}$ are the random interaction terms,

$\varepsilon_{\mathrm{ijkl}}$ is the error term.

Linear models were analyzed with the General Linear Models (GLM) procedure of the SAS statistical package (SAS Institute Inc. 1990). Mean separation was done with Tukey's HSD test, and preplanned comparisons of particular treatment effects were tested with contrasts (LITTELL et al. 1991).

\section{RESULTS AND DISCUSSION}

\section{Weed vegetation in spring cereals}

\subsection{Species composition of weed flora}

Weed flora in spring cereal fields surveyed in 19821984 was dominated by relatively few species (I). The number of abundant weeds per field averaged 7 species (range 2-13) of the 33 species studied. Chenopodium album and Galeopsis spp. were the most frequently occurring species (I, ERVIÖ and SALONEN 1987). These species, among others, are well adapted to the prevailing conditions in cultivated fields. They have succeeded in maintaining viable seeds in the soil seed bank, despite the frequent use of herbicides. The frequency of the four most common species (>80\%) was considerably higher in the Finnish fields than in cereal fields in Denmark, where the frequency of all of the species remained below 60\% (ANDREASEN 1990). Apparently this is due to differences in growth conditions (soil, climate) and in crop rotation practices, but also due to a different definition of the frequency values in these two studies.

All germination groups of annual weeds (see p. 10) were represented in spring cereal fields studied (I). The most common grass weed was Elymus repens. It was even more frequent than in the $1960 \mathrm{~s}$ (ERVIÖ and SALONEN 1987). Elymus repens had, on average, the highest biomass production per unit area. Poа аппиа L. was the second most frequent grass weed. Avena fatua $\mathrm{L}$. is of local importance in coastal regions, although it was rare in the fields surveyed.

Five regions of the survey area were located in southwestern Finland, three in eastern Finland and two in the western part of central Finland. Consequently, the frequency results of weed species 
(Table 1 in I) affected by the unequal number of fields from different geographical regions. Nevertheless, the data set reflects the distribution of cereal fields in Finland, and thus the most important weed species affecting cereal production.

Connections between geographical regions and the species composition of weed populations were indicated with ordination analyses (I). Characteristic weed species in southern Finland were volunteer turnip rape (Brassica rapa L. subsp. oleifera DC. alias B. campestris L.), Fumaria officinalis, Lamium spp., Stellaria media and Tripleurospermum inodorum, whereas Lapsana communis, Elymus repens, Myosotis arvensis and Achillea L. spp. were common in central Finland.

The occurrence of particular weed species was also related to management practices and to soil properties (I), as reported from other studies (GRANSTRÖM 1962, BACHTHALER 1969, RADEMACHER et al. 1970, STREIBIG et al. 1984, DALE and THOMAS 1987, ANDREASEN et al. 1991, DALE et al. 1992). Cereals dominated the crop rotations in southern Finland, where soils were mostly clay type, whereas in central Finland mixed crop rotations in coarse and organic soils were typical. Thus, the geographic regions and farming practices were associated.

In addition to the management practices and soil types, it is evident that the cropping history of each field affects the weed incidence (HAAS and STREIBIG 1982). Ordination analysis with CCA indicated the high relative importance of management practices, particularly continuous herbicide use, in determining the species composition of weed flora (I). However, in this study no single factor determining the composition of weed populations in spring cereal fields in Finland could be identified either by regression analysis (ERVIÖ and SALONEN 1987) or by ordination analysis (I).

Ordination techniques applied in this study were chosen from among a group of mathematically diverse approaches. Illustrations on species-environment interactions have been produced also with other numerical methods such as factor analysis (STREIBIG 1979) and canonical discriminant analysis (LÉGÉRE et al. 1993). However, CCA and its implementation in the computer program
CANOCO has received wide acceptance in ecological research (BIRKS and AUSTIN 1992), presumably due to its sound ecological basis and welldocumented theory and practical implications reported by TER BRAAK (1987b).

The most common weed species were well represented in the field trials (III-V). Weed incidence was not static during the growing season nor between the seasons (V, SALONEN 1993). Galeopsis spp. were typical species, emerging early in the growing season, whereas Stellaria media and Viola arvensis increased their relative proportion in the weed population towards the end of the growing season. These observations on fluctuations in weed incidence agree with results of earlier studies conducted in the Nordic countries (ERVIÖ 1981, HÅKANSSON 1983a, 1992, ANDREASEN 1990, FYKSE 1993a).

Long-term changes in species composition of weed populations are of great importance. Assessment of the diversity of weed communities provides information on the compositional changes caused by agricultural practices (TOMKINS and GRANT 1977). In this study, the number of weed species surveyed in 1982-1984 was restricted to 33 (I). The remainder of the observed species were pooled in the groups of "other dicots" and "other monocots", and thus the total number of weed species occuring in spring cereal fields is not reported. Quantitative and qualitative changes in weed incidence between the 1960s and 1980s were reported in detail by ERVIÖ and SALONEN (1987).

MUKULA et al. (1969) found a total of 304 weed species in the 2,710 spring cereal fields surveyed in southern and central Finland in the 1960s. In 1983, KALLIO-MANNILA et al. (1984) returned to 73 of the spring cereal fields in central Finland studied by MuKULA et al. (1969) in the 1960s and found that the number of weed species had decreased in that particular region from 119 to 90 . Weed species that had disappeared (e.g. Centaurea cyanus L., Campanula rotundifolia L., Ranunculus auricomus L. and Hieracium pilosella L.) were of minor importance already in the 1960 s (MUKULA et al. 1969). In contrast, ANDREASEN (1990) found that the number of weed species occurring in Denmark had not decreased from the $1960 \mathrm{~s}$, although the 
frequency of several species has drastically declined.

\subsection{Weed infestation levels in cereal fields}

The level of weed infestation was clearly a dynamic phenomenon as considerable differences in weed density and weed biomass were observed both within a growing season and between seasons (III, V, SALONEN 1993). According to a continuous series of observations over four years (V), weed density at the time of herbicide application varied annually in the same field e.g. from 52 to 300 weeds $\mathrm{m}^{-2}$ in Jokioinen and from 163 to 702 weeds $\mathrm{m}^{-2}$ in Kokemäki. There were no clear trends of increasing weed densities (No. $\mathrm{m}^{-2}$ ) even in untreated plots. The great annual fluctuations in above-ground weed populations fully agree with the observations of FYKSE (1993a) and HALLGREN (1993a).

In the weed survey, the average density of weeds was 170 plants $\mathrm{m}^{-2}$ (median 124), and the average weed biomass was $320 \mathrm{~kg} \mathrm{ha}^{-1}$ (median 183)(I). In the $1960 \mathrm{~s}$, the weed infestation in sping cereal fields averaged 550 plants $\mathrm{m}^{-2}$ and $1000 \mathrm{~kg} \mathrm{ha}^{-1}$, respectively (MUKULA 1974). Observations were made, both in the 1960s and 1980s, in unsprayed sample plots in July, i.e. at a time when most of the weeds had emerged, but only a few had withered (c.f. MuKULA et al. 1969). Although the data on weed infestation levels are already ten years old, they are presumably still valid since the changes in agricultural practices have been much less during the 1980 s than during the 1960 s and 1970s. Moreover, AAMISEPP and WALLGREN (1979) and HALLGREN (1993a) have shown that the decline in weed infestation has slowed in Sweden.

In the field trials (III, IV, V), the density of annual broad-leaved weeds at the time of spraying ranged from 7 to 700 weeds $\mathrm{m}^{-2}$, averaging $70-75 \%$ of the infestation one month later $(\mathrm{V}$, SALONEN 1993). Crop density did not significantly affect the number of weed seedlings per unit area at the time of spraying, however, higher crop densities had an inhibitory effect on weed growth later in the growing season (III, SALONEN 1993).

Annual broad-leaved weed species were pre- dominant in the survey fields and accounted for $77 \%$ of the total weed biomass (II). However, none of these species reached the same mean biomass production per plant as the crop plants (V). The most aggressive weed species were volunteer turnip rape (Brassica rapa ssp. oleifera), Galeopsis spp. and Fallopia convolvulus, which produced biomass within the range of $0.15-0.60 \mathrm{~g} \mathrm{DW}$ per plant (V). The dry weight of a barley plant averaged $1.10 \mathrm{~g}$ and that of a wheat plant $1.02 \mathrm{~g}$ in crop stands sown at the recommended seeding rates of 450 viable seeds $\mathrm{m}^{-2}$ for barley and 600 for wheat $(\mathrm{V})$.

In conclusion, based on the results from the weed survey (I, II) and from the field experiments (III, IV, V), the most common weed species were ranked to indicate their relative importance in spring cereal production in Finland (Table 5). It should be noticed, however, that any of these species can be harmful in one particular field where the cropping history and environmental conditions have favoured their growth. Moreover, efficient removal of the most competitive weed species with herbicides may be advantageous for herbicide-tolerant species, as discussed later in this thesis.

\section{Chemical weed control in spring cereals}

\subsection{Use of herbicides}

In total, 22 different herbicide products were used by farmers in the survey fields in 1982-1984 (II). MCPA-containing herbicide formulations were the most commonly applied. MCPA alone, and in mixtures with dichlorprop and mecoprop, constituted $91 \%$ of the total number of herbicide treatments. The observed distribution of different herbicides sprayed in the survey fields agreed with the sales statistics (Fig. 2).

A recommended dose range of a herbicide is indicated on the product label. The dose recommendations are proposed by the manufacturer, and the herbicide is screened in official field trials and approved by the authorities. In Finland, the official body releasing the herbicides onto the market is the Pesticide Commission. At present, label informa- 
Table 5. Relative importance of different weed species in spring cereal production in Finland. The ranking of weeds is based on their occurrence (frequency), adverse effect on crop (interference) and their susceptibility to chemical weed control with special emphasis on the need for improved herbicide efficacy.

\begin{tabular}{llll}
\hline $\begin{array}{l}\text { Importance } \\
\text { Weed species }\end{array}$ & Frequency ${ }^{1}$ & $\begin{array}{c}\text { Ranking factor } \\
\text { Interference }\end{array}$ & Control $^{3}$ \\
\hline
\end{tabular}

\section{Major}

Chenopodium album $\mathrm{L}$.

Galeopsis spp. L. (G. speciosa, G. tetrahit, G. bifida)

Elymus repens (L.) GOULD

Viola arvensis MURRAY

Stellaria media (L.) VILL.

Lapsana communis L.

Fallopia convolvulus (L.) Á. LÖVE

Brassica rapa L. ssp. oleifera DC.

Sonchus arvensis $\mathrm{L}$.

Avena fatua $\mathrm{L}$.

$\begin{array}{rrr}* * * & * * * & * \\ * * * & * * * & * \\ * * & * * * & * * \\ * * * & * * & * * \\ * * & * * * & * * \\ * * & * * * & * * \\ * * & * * * & * * \\ * * & * * * & * * \\ * & & * *\end{array}$

Moderate

Polygonum aviculare L.

Polygonum lapathifolium L.

Erysimum cheiranthoides L.

Myosotis arvensis (L.) HILL

Spergula arvensis $\mathrm{L}$.

Fumaria officinalis L.

Lamium spp. L. (L. purpureum, L. hybridum)

Cirsium arvense (L.) SCOP.

Tripleurospermum inodorum SCHULTZ BIP.

Galium spp. L. (G. spurium)

Minor

Thlaspi arvense $\mathrm{L}$.

Capsella bursa-pastoris (L.) MEDIK.

Matricaria matricarioides (LESS.) PORTER

Sonchus spp. L. (S. asper, S. oleraceus)

Ranunculus repens $\mathrm{L}$.

Equisetum spp. L. (E. arvense)

Poa annua $\mathrm{L}$.

Rumex spp. L. (R. acetosa, R. acetosella)

Gnaphalium uliginosum L.

Achillea spp. L. (A. millefolium, A. ptarmica)

\begin{tabular}{|c|c|c|}
\hline$* *$ & $* *$ & $* * *$ \\
\hline$* *$ & $* * *$ & $* *$ \\
\hline$* *$ & $* *$ & $*$ \\
\hline$* *$ & $*$ & ** \\
\hline ** & $* *$ & * \\
\hline$* *$ & $* *$ & $* *$ \\
\hline$* *$ & $* *$ & $* *$ \\
\hline$*$ & $* * *$ & $* *$ \\
\hline$* *$ & $* *$ & ** \\
\hline$* *$ & $* *$ & ** \\
\hline$*$ & $* *$ & * \\
\hline$*$ & $*$ & $*$ \\
\hline$*$ & $* *$ & ** \\
\hline$*$ & $* *$ & $* *$ \\
\hline * & $*$ & ** \\
\hline$*$ & $* *$ & $*$ \\
\hline$*$ & * & $* * *$ \\
\hline$*$ & $* *$ & $* *$ \\
\hline$*$ & $*$ & $* *$ \\
\hline$*$ & $* *$ & ** \\
\hline
\end{tabular}

\footnotetext{
1 Frequency: ${ }^{*}:<30 \%,{ }^{* *}: 30-60 \%,{ }^{* * *}:>60 \%$

2 Interference (competitiveness): ${ }^{*}$ : weak, ${ }^{* *}$ : intermediate, ${ }^{* * *}$ : strong

${ }^{3}$ Control (with current herbicides): ${ }^{*}$ : easy, ${ }^{* *}$ : moderate, ${ }^{* * *}$ : difficult
}

tion for dose adjustment deals only with the recommended dose range. The survey conducted in farmers' fields in 1982-1984 indicated that most of the farmers followed the dose recommendations. However, a survey carried out in 1991 in cereal farms in southern Finland showed that reduced herbicide doses were applied in $16 \%$ of the 300 spring cereal fields studied (SALONEN 1992a).

\subsection{Efficacy of herbicides}

Herbicides provided good weed control, defined here as $>70 \%$ reduction of weed biomass following herbicide application, in $68-84 \%$ of the fields studied in weed survey (II). In general, mixtures of phenoxy acids provided more efficient and reliable control than MCPA alone (Fig. 5). On average, 


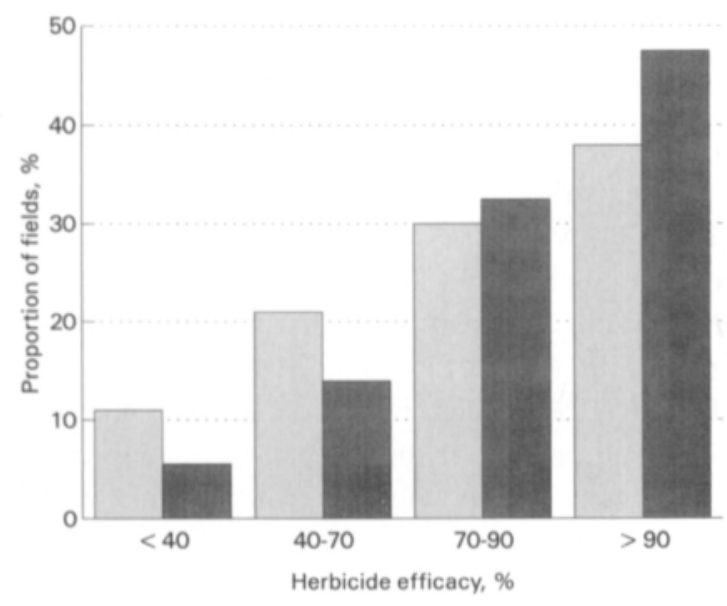

Fig. 5. Comparison of the herbicide efficacy ( $\%$ reduction of weed biomass) achieved with MCPA (left bar) and with the mixtures of MCPA/dichlorprop or MCPA/mecoprop (right bar). Distribution of the 252 spring cereal fields into efficacy classes. Data compiled from the Table 3 in II.

MCPA alone gave only moderate control (65\%), while the efficacy of the other herbicides averaged $83 \%$ (II). Only general conclusions on the effect of different herbicides can be drawn from the weed survey, since herbicides were applied in a variety of conditions. This, however, was the first extensive study on herbicide efficacy in cereal fields in Finland and it indicated that the efficacy of herbicides in practice corresponds with the efficacy achieved in field trials (e.g. AAMISEPP 1984, JUNNILA 1990, III, V).

In the field experiments (V), the lowest recommended doses of phenoxy mixtures provided on average as high as $80-90 \%$ control, even though the choice of herbicide was not based on the prevailing weed populations. Statistically significant Year * Site * Treatment interactions indicated that the herbicide efficacy was site-specific and fluctuated between the years $(\mathrm{V})$.

Herbicides were applied to natural weed vegetation, comprising several weed species, and resulted in selective control of the different weed species (III, V). Consequently, removing some of the competitive but susceptible species (e.g. Chenopodium album, Galeopsis spp.) provided more space for less competitive but herbicide-tolerant species (e.g.
Fumaria officinalis, Viola arvensis). As a result, biomass production of the tolerant species was sometimes higher in treated plots than in untreated plots. HALLGREN (1993b) reported similar results for $V$. arvensis in cereal experiments in Sweden.

The incidences of low efficacy (\%-scale) of herbicides were mainly explained by the application of an inappropriate herbicide for the prevailing weed population, but also by the fact that weed infestation was sometimes low even in unsprayed plots (V). Thus, the difference in weed biomass between sprayed and unsprayed plots remained low. Consequently, efficacy results, given on a relative scale (\% control), hid the actual level of weed infestation and the need for control in low infestation situations e.g. at Jokioinen in 1986 (III) and several research stations during 1989-1991 (V). Therefore, the results were reported as changes in weed density $\left(\right.$ No. $\left.\mathrm{m}^{-2}\right)$ or weed biomass $\left(\mathrm{g} \mathrm{m}^{-2}\right)$ on a quantitative scale, to give a realistic account of the weed infestation in cereal stands of the field experiments (V).

The new active ingredient, fluroxypyr, showed no particular advantage over the other herbicides, since it is a narrow-spectrum herbicide active against particular species including Galium spp., which were not abundant in our field experiments (III, V). On the other hand, the low dose herbicide tribenuron-methyl provided broad-spectrum control (V) and is likely to become one of the standard herbicides used in cereal production in Finland.

In general, all herbicide products included in our experiments were effective for weed control in spring cereals providing that species composition of weed population was considered as a determining factor in choosing the herbicide. No commercial herbicide product covers the entire range of the most common weed species. To overcome this problem, mixtures of different herbicide formulations can be used when necessary.

\subsection{Impact of dose reduction on herbicide efficacy}

Reduction of the herbicide dose did not cause a corresponding reduction in efficacy against broadleaved weeds. Halving the highest recommended 
dose of MCPA/mecoprop and MCPA/fluroxypyr reduced the average efficacy (\% control) of $88 \%$ with recommended doses to $76 \%$ with reduced doses (Fig. 3 in III). Further dose reduction to onethird of that recommended resulted in highly variable levels of control, mainly because the examined herbicides were either not effective or their efficacy against some weed species (e.g. Viola arvensis) declined considerably when the dose was reduced.

The efficacy of MCPA/dichlorprop-P, MCPA/ fluroxypyr and MCPA/mecoprop-P, applied with the lowest recommended doses, averaged $85 \%$, and $79 \%$ with $30 \%$ lower dose, respectively (V). A considerable ( $>15 \%$ units) difference in the efficacy between the plots treated with recommended and reduced doses was observed in $8-29 \%$ of the cases depending on the herbicide, weed species and the crop. Moreover, to summarize the results of the field experiments during 1989-1991 on a quantitative scale, weed densities from 7 to 700 weeds $\mathrm{m}^{-2}$ were observed in spring cereal experiments at the time of spraying in June (V). The weed biomass, recorded one month later, averaged 12.8 (SE 1.4) g DW $\mathrm{m}^{-2}$ in unsprayed plots, 1.8 (SE 0.2) $\mathrm{g} \mathrm{DW} \mathrm{m}^{-2}$ in the plots treated with the lowest recommended herbicide doses and 2.2 (SE 0.2) $\mathrm{g} \mathrm{DW} \mathrm{m}^{-2}$ in the plots treated with $30 \%$ lower doses, respectively.

As an example of other studies, JENNÉUS (1992) showed on demonstration trials on farmers' fields in Sweden that an adequate reduction of weed biomass (below $50 \mathrm{~g}$ fresh weight $\mathrm{m}^{-2}$ ) in spring cereals was achieved in $55 \%$ of cases with $1 / 4$ of the normal herbicide dose, and in $70 \%$ and $91 \%$ of cases with $1 / 2$ and $1 / 1$ of the normal dose, respectively, using herbicides chosen by the farmer.

The efficacy of MCPA/fluroxypyr decreased more rapidly than that of MCPA/mecoprop when reduced doses were applied (III). Halving the highest recommended dose reduced the efficacy of MCPA/mecoprop on average by $7 \%$-units and the efficacy of MCPA/fluroxypyr by $14 \%$-units. This can be interpreted as either $i$ ) dose recommendations for new products (MCPA/fluroxypyr) are closer to the optimum than recommendations for old products (e.g. MCPA/mecoprop) or ii), more likely, that fluroxypyr was, to a lesser extent than mecoprop, supplementing the efficacy of MCPA against the weed species that predominated in our field experiments.

Relatively slight reduction in efficacy with reduced doses is in accordance with the results of other experiments (e.g. AAMISEPP 1984, PALLUTT 1988, Proven et al. 1991). In the case of inadequate control, split applications at reduced rates have been suggested if the first application is not successful (PALlUtT 1988, MEINLSCHMIDT and KARCH 1992). Such an approach could be more useful in practice if the second application coincided with e.g. spraying of growth regulators or insecticides against cereal aphids. Otherwise split applications are hardly cost-effective due to relatively high costs (machinery, labour) of herbicide application.

Dose reduction of herbicides caused differential changes in efficacy against weed species (III, V). Typically, the level of control of Chenopodium album was over $95 \%$ even at the lowest doses, while the efficacy against e.g. Viola arvensis rapidly decreased when the herbicide dose was reduced. As an example, the efficacy of MCPA/ fluroxypyr against $V$.arvensis decreased from $78 \%$ at the full dose to $52 \%$ and $44 \%$ when the dose was reduced to one-half and one-third, respectively (III).

Within the range from one-third to the highest recommended dose screened in our experiments (Table 4), a linear response model between herbicide dose and the remaining weed biomass appeared to be a feasible approximation (III). On the other hand, the dose range screened in the experiments was insufficiently broad to determine the shape of the response curve within the entire range from zero to the recommended dose. A linear response model, including two explanatory factors, herbicide dose and crop density, was fitted to field data (Table 3 in III). The results indicated the higher relative power of herbicides to suppress weed growth compared with crop density. As an example, the "weed biomass - herbicide dose - crop density" relationship is graphed (Fig. 6) by fitting a response surface on the weed data from a field experiment, in spring wheat in 1988, when the greatest weed infestation was recorded during the three-year field experiment (III). 


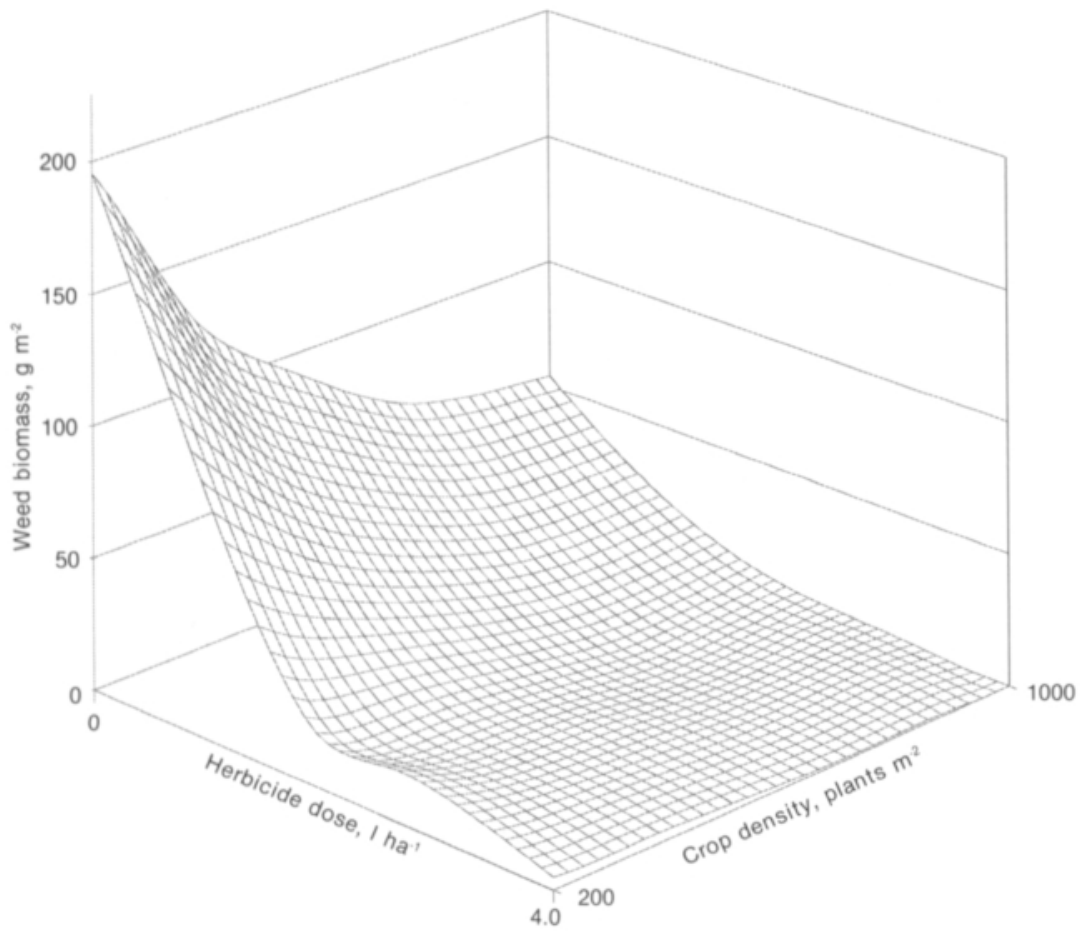

Fig. 6. Response surface of the effect of herbicide dose (MCPA/mecoprop formulation) and crop density on the weed biomass fitted to the data from the spring wheat experiment at Jokioinen in 1988 (III).
Regarding competition, crop seeding rate is in many respects an analogous management practice to herbicide dose in attempting to suppress the growth of weeds (HÅKANSSON 1986). In our experiments, weed growth was more efficiently suppressed by herbicides, even at low application rates, than by increasing crop seeding rates above the recommendations (III, Fig. 6). However, a dense crop was advantageous in maintaining the weed growth at low levels towards harvest. This was detected particularly when the herbicide effect was only moderate, as in our field experiments in Ylistaro (see Table 3 in III). Nevertheless, weed control through increased seeding rates above the optimum for yield production is not economically meaningful compared with the use of herbicides even at very low rates of application (III).

Substantial reduction in the recommended dose of herbicides is possible only if a herbicide is chosen according to the weed species and is applied at early growth stages of weeds under favourable conditions (KUDSK 1989). Satisfactory control of weeds in our experiments is apparently explained by the fact that most of the weed seedlings were at an early growth stage (cotyledon stage - first true leaves) at the time of herbicide application (V). Evidently, recommended herbicide doses are still needed in cases of delayed application, under adverse growth conditions, particularly in uneven crop stands, and against specific weed species (see also KUDSK 1989).

\subsection{Yield responses to chemical weed control}

Yield differences between untreated plots and plots treated with herbicides was, in most cases, below $5 \%$ in crop stands sown at the normal seeding rate $(\mathrm{IV}, \mathrm{V})$. Moreover, yield response to herbicide dose was low, particularly in spring barley, irrespective of the yield levels, which varied between the sites and years (IV). Only in one trial out of the 21 spring wheat trials wheat yield was significantly $(\mathrm{P}<0.01)$ lower in the plots treated with reduced doses of 
MCPA/mecoprop-P and MCPA/fluroxypyr than in the plots treated with recommended doses. Small yield responses from chemical weed control clearly indicate the relevance of minimized herbicide inputs in cost-effective cereal production.

Responses of crop yields to herbicide application were even negative in $32 \%$ of the wheat plots, and in $43 \%$ of the barley plots (IV). In the spring cereal fields of our weed survey in 1982-1984 chemical weed control was profitable in $60 \%$ of fields (ERVIÖ et al. 1991). GEROWITT et al. (1984) reported that only $50 \%$ of herbicide treatments in spring barley were profitable in Germany.

The crop yield was often higher in the plots treated with reduced herbicide doses than in those which received the highest recommended dose (IV). Although phenoxy herbicides caused neither visual phytotoxic symptoms in crop plants nor decreased their dry weight, cereal plants may on occasion have been at a sensitive development stage (from 'mid-vegetative' to 'double ridge' stage), in terms of ear distortions, as discussed by THOMSON and StOKES (1985) and KIRBY et al. (1989). Nevetheless, statistically significant differences in yield parameters (1000 kernel weight, bulk weight etc.) between untreated and treated plots were detected only in a few cases in our field experiments (IV). Similarly, the yield quality was not affected by chemical weed control in the fields of our weed survey (ERvıö et al. 1991).

The impact of seeding rate on crop-weed interactions, and consequently on yield response, was more significant in wheat than in barley (Fig. 1 in IV). Nevertheless, even in sparse wheat stands the same yield level was reached both at reduced as well as at recommended herbicide doses. On the other hand, high rates of application were profitable in terms of yield if less susceptible weed species, such as Tripleurospermum inodorum, were prevalent in the experimental site (IV, V).

The recommended sowing densities for spring barley $\left(450\right.$ seeds $\left.\mathrm{m}^{-2}\right)$ and for spring wheat $(600$ seeds $\mathrm{m}^{-2}$ ) are higher in Finland than in more southerly situated countries due to the strong dominance of the main stem of cereals under our long-day conditions (Mela and PAATELA 1974, PELTONENSAINIO and JÄRVINEN 1993). Apparently, the re- commended seeding rates for spring cereals are high enough to assure the competitive advantage of the crop stand against weeds (III). Increase of crop density above the recommended seeding rate gave an insignificant benefit, particularly in barley, in limiting the growth of weeds. This has also been reported by HÅKANSSON (1975) and ERVIÖ (1983). The highest crop density (900 and 1000 viable seeds $\mathrm{m}^{-2}$ for barley and wheat, respectively) used in our experiments (III, IV) was too dense, often yielding lower than the less dense crop stands (IV). It is likely that the crop was suffering from intraspecific competition and lack of nutrients.

Although yield responses were sometimes erratic (IV), the general conclusion was that in most cases reduced herbicide doses were sufficient to guarantee the same yield level as the recommended doses. The benefit of efficient weed removal was partly lost when unnecessarily high levels of herbicide were applied, since higher yield were achieved from the plots treated with lower doses (Fig.4 in IV), as discussed also by THONKE (1986) and by COURTNEY (1991).

The results from experimental fields on low yield responses to herbicide application are in agreement with the observations in the weed survey; the crop yield in treated areas was, on average, only 3\% higher than in untreated ones (ERviö et al. 1991). Hughes (1966) and Evans (1968) reported that the control of broad-leaved weeds in the U.K. had little impact on cereal yields already in the 1960s. Similar results were reported in the 1980 s by COURTNEY and JOHNSTON (1986), by DAVIES et al. (1989) and in Scandinavia by JENSEN (1985). Significant yield increases tend to be detected only when high densities of competitive weed species are treated with herbicides (SCRAGG 1980, WILSON 1982, LOTZ et al. 1990).

\subsection{Basing the herbicide use on crop-weed interactions}

Decisions on the type and application rate of herbicides have to be based on observations and predictions which are made at the beginning of the growing season. However, in our field trials there was a 
poor correlation between the weed density at the time of spraying and the biomass production of weeds later in the summer (III, V). As discussed earlier, several hundreds of weeds $\mathrm{m}^{-2}$ at the time of spraying had little effect on crop yield in some trials, whereas in others only a few weeds reduced the crop yield significantly. This is reflected in the weak correlation $(\mathrm{r}=0.48)$ between the total number of annual weeds per unit area $\left(\mathrm{m}^{2}\right)$ and weed biomass in untreated plots.

In general, the density-based thresholds were found unreliable (IV, V), as discussed also by BEHRENDT (1986) and by BLEIHOLDER and NUYKEN (1986). The results from field plots with multispecies weed infestation are in accordance with the results of field experiments with single weed species (LUTMAN 1992). Thus, predictions on yield loss according solely to the weed density (Table 3) should be interpreted with caution in spring cereal production in the Nordic regions, and regarded only as indicative of trends.

In spite of critical reviews against the threshold approach to weed control, the strategy is applied in practice e.g. in Norway and in Germany (HEITEFUSS et al. 1987, FYKSE 1993b). In Norway, farmers are advised through an integrated telefone-computer system TELEVIS (FYKSE 1993c). It is based on a threshold model which takes into account the weed species that occur in the field, the number of weeds per unit area and moreover the \% cover of crop and weeds (FYKSE 1991b). In Germany, the threshold approach is applied particularly in winter cereals, resulting in approximately $65 \%$ correct control decisions in terms of profit margin (GEROWITT et al. 1986). By applying the threshold approach in that study, herbicide use was witheld in $26 \%$ of cases in winter barley and winter wheat, and in $36 \%$ of cases in winter rye. A more recent validation of that decision model resulted in withholding chemical weed control in $45 \%$ of cases in winter wheat (GEROwITT 1992).

Weed biomass produced by the broad-leaved weed species in the field experiments was relatively low compared with crop biomass even in untreated crop stands; the proportion of weeds was seldom higher than $5 \%$ of the total vegetative biomass in crop stands sown at the normal seeding rates (V).
Thus, the effect of weeds on crop yield often remained below the statistically significant level. On the other hand, in crop stands sown at low seeding rates (100 and 200 seeds $\mathrm{m}^{-2}$ of barley and wheat, respectively) the proportion of weeds often increased, reaching approximately $20 \%$ of the total biomass (III, SALONEN 1992b), and yield increase achieved with chemical weed control in wheat was in some cases more than $30 \%$ (IV).

Growth habit and the ability of a weed species to grow under low light intensity are important factors in competition between plants (FOGELFORS 1974). Typically, only a few broad-leaved weed species can successfully compete with cereal plants: WILSON (1986) ranked only Galium aparine L. more aggressive than winter wheat and DocK GuSTAVsSON (1986) reported that only Sinapis arvensis L. out-competed barley. In the experiments of JENSEN (1991a), in Denmark, Brassica napus L., Sinapis arvensis L. and Galeopsis spp. were the most effective biomass producers in spring-sown crops.

In addition to botanical factors, edaphic factors can affect crop-weed interactions. Benefits from weed control are expected to be higher in soil types other than clay, because the production of weed biomass per plant was higher in coarse and organic soils than in clay soils (I), which were predominant in the field experiments. Indeed, yield responses of spring barley to chemical weed control have been found to be lowest in clay soils (JENSEN 1985, HALLGREN 1988).

Some explanations for low yield responses can be given. The relative time of emergence is considerd to be of great importance in crop-weed competition (c.f. HÅKANSSON 1983b, COUSENS et al. 1987, HÅKANSSON 1991). In the field trials of PROJECT 3, crop plants normally reached the second leaf stage (stage 12-13 on the Zadoks' scale) before the flush of annual weeds (V). Apparently, this was an advantage for crops in competition with weeds.

In addition to direct control methods discussed above, some additional considerations on indirect methods can be given. The barley variety 'Arra', used in PROJECT 2 (III), is characterized by rapid initial growth (JOKINEN 1991). The good competitive ability of this variety apparently partly explains the low production of weed biomass in our trials. In 
fact, now that indirect methods for weed control are emphasized, the use of competitive varieties has been suggested as a potential means of reducing the use of herbicides. (Moss 1985, RICHARDS 1989, RICHARDS and DAVIES 1991, WHITING et al. 1991, Christensen 1993). Christensen et al. (1990) reported that the same level of weed control was achieved using the most competitive barley variety with only one-third of the herbicide dose needed for weed control in fields of the least competitive barley variety.

In addition, the current management practices in Finland, with placement of fertilizers, obviously favour the nutrient uptake and growth of the crop particularly in the early stages of growth. This gives an advantage to crops in competition with weeds (ESPEBY 1989, SALONEN 1992b).

Extensive research has been focused on the nature and effects of competition between the crop and weeds. Quantification of yield responses is often based on growth densities of the crop and the weeds (e.g. HÅKANSSON 1983b, SPITTERS and VAN DEN BERGH 1982). It seems, however, that the status of competition between the crop and weeds at the time of herbicide application should be defined more precisely than has so far been done in threshold models (PALLUTT and RODER 1992). One recent approach is to estimate the required weed control with a relative leaf cover model (KROPFF and SPITTERS 1991). In this approach, predictions of yield loss caused by weeds are based on relative leaf area of weeds compared with leaf area of the crop. Several working groups within the European Weed Research Society, including one at the Institute of Plant Protection in Jokioinen, are validating the performance of that particular model under different environmental conditions (LOTZ et al. 1993). In addition, Assémat (1992) has suggested that the species-environment interaction influencing the growth rates of weeds (and crops) should be studied in more detail instead of introducing average growth parameters into the prediction models.

In conclusion, regarding the estimation of yield losses caused by weeds in spring cereals in Finland, the most difficult problem is accurate assessment of relatively low levels of weed infestation and predic- tion of their growth potential during the growing season.

\subsection{Impact of herbicides and crop rotation on weed infestation}

When herbicide use is drastically decreased or completely stopped, weed control has been reported to create major problems, particularly in low-input farming systems (EDWARDS and REGNIER 1989). Subsequent effects of crop rotations and different herbicides and their application rates on weed infestation were followed in PROJECT 2 in Jokioinen. Differences in subsequent weed infestation, one year after the three-year trial period, were detected between the crop rotations, and between untreated and treated plots, but not significantly between different herbicides and their rates of application. The subsequent weed infestation in untreated plots of wheat-barley-wheat rotation averaged $715( \pm 88)$ weeds $\mathrm{m}^{-2}$, whereas the weed density in barley-wheat-barley rotation remained at the level of $336( \pm 50) \mathrm{m}^{-2}$ (III). On the other hand, in treated plots of both rotations the mean density was $265( \pm 7)$ weeds $\mathrm{m}^{-2}$. No significant differences in weed infestation between herbicides (MCPA/fluroxypyr, MCPA/mecoprop) and their rates of application were detected (III). Thus, if herbicides are continuously applied, even with reduced doses only, farmers can more freely choose their crop rotations without causing any significant adverse effect on the subsequent weed infestation.

Similarly in PROJECT 3, the subsequent weed infestations were recorded from plots treated with different herbicides (MCPA/dichlorprop, MCPA/ fluroxypyr, MCPA/mecoprop, tribenuron-methyl) and at different rates of application (the lowest recommended and $30 \%$ lower dose). No significant differences in weed infestation between the treatments were detected after continuous use of herbicides during the three-year trial period (V). JENSEN (1991b) suggested that the level of weed infestation can be kept stable either by applying half recommended herbicide doses every year, or alternatively by applying full doses every two years out of three.

Production of weed biomass was significantly 
higher in wheat than in barley stands (Fig. 1 in III, SALONEN 1993). Evidently, the production of weed seeds was also higher in the wheat plots than in barley plots since the production of weed seeds has been found to be linearly related to the weed biomass (WILSON et al. 1988, DEBAEKE 1988, PEDERSEN and RASMUSSEN 1990). Moreover, it is likely that a 20 - to 30 -day longer growing season required by spring wheat in comparison with spring barley was effectively used by the annual weeds for seed production, maturation and shedding.

Although ploughing the fields every autumn partly buffered the changes in weed infestation, the increase in weed infestation was detected in the wheat-dominated rotation within three to four years. Thus, competitive ability of the crops included in the crop rotation is of great importance in long-term weed management, as emphasized in other studies (ZWERGER et al. 1990, HINTZSCHE 1990). In addition to the choice of crop, the level of weed infestation is obviously also influenced by crop management practices such as tillage (KNAB and HURLE 1986, LÉGÉRE et al. 1990). At present, the most severe threat of increasing weed infestation in Finnish fields is neglected weed management in the obligatory set-aside fields.

Changes in weed infestation were detected not only as the number of weeds emerging in spring but also in the seed bank of weeds in the soil. In PROJECT 2 (III), observations from soil samples revealed that the weed seed reservoir was significantly $(\mathrm{P}<0.001)$ higher after a wheat-dominated rotation than after a barley-dominated one (Fig. 5 in III). However, even in wheat, reduced rates of herbicide application were sufficient to keep the subsequent weed infestation at the same level as normal rates. Also LAwSON et al. (1992) found that treatment with $50 \%$ normal dose incurred no penalty in terms of weed seed banks in soil.

Although herbicides evidently exert a selection pressure on weed communities (STRYCKERS 1979), the response in weed communities to continuous use of herbicides was, in our trials, in the first place quantitative and not so much qualitative. This is in agreement with results from earlier studies by MAHN and HELMECKE (1979) and by HUME (1987). Similarly, ERVIÖ and Hitvola (1986) found no changes in the species composition of weed populations in spring wheat experiments after different control regimes (recommended herbicide dose, half dose and threshold treatment) imposed for five years in Finland. In contrast, KEES (1986) found changes in the species composition of weed populations after four years of different weed control regimes ("maximum", "threshold" and "every 2nd year control") in a four-year rotation (sugarbeet - winter wheat - spring barley - spring oats) in Germany. CATIzonE et al. (1990) found during a five-year study that herbicides had a marked influence on the species composition of weed populations in a continuous winter wheat experiment in Italy.

Slow alterations in weed populations in relation to control regimes in Finnish conditions may be due to a short growing season in relation to the winter period. Factors related to our growing conditions may affect both weed seed production and mortality of weed seeds in the soil. Even so, long-term selection pressure in weed populations, caused by management practices and herbicide use, affects the species composition of weed populations as detected in the weed survey (I). However, the results based on the above-ground observations on changes in species composition should be interpreted with caution, since the above-ground weed infestation has been shown to correlate only weakly with the level and species composition of weeds in the seed bank in the soil (FYKSE 1993b).

The results of changes in species composition of weed populations in PROJECT 2 in Jokioinen have been reported elsewhere (SALONEN 1993). However, in summary: the occurrence of Chenopodium album increased particularly in untreated plots in the wheat-dominated rotation, and Viola arvensis proportionally increased in the barley-dominated rotation, even in herbicide-treated plots. Chenopodium album is well-known for its high seed production capacity; a recently published figure is 7,00030,000 seeds $\mathrm{m}^{-2}$ in an untreated crop stand of spring barley (RASMUSSEN 1993).

The proportion of $V$. arvensis increased in three years from approximately zero to almost $50 \%$ of the total number of weeds (SALONEN 1993). Viola arvensis was relatively tolerant of herbicides applied 
in our experiments, particularly of low rates of application. Furthermore, as mentioned earlier, the proportion of weed seedlings that emerged before herbicide application averaged $70-75 \%$ of the peak infestation determined one month later. Apparently, some $V$. arvensis plants emerged after herbicide application in the beginning of June, since ERVIÖ (1981) has observed that e.g. V. arvensis and Lamium spp. reach their emergence peak during mid-summer. The late emerging plants are able to produce seeds, particularly if there are gaps in the crop stand (NIEMANN 1990).

\section{Economic impact and practical implications of herbicide dose reduction}

Appraisals of the economic return from weed control should be based on $i$ ) the density of each weed species, ii) their relative competitiveness, iii) the estimated weed free yield, $i v$ ) the level of weed control expected with the herbicide, $v$ ) the anticipated net value of the crop and vi) the cost of selected treatment (COMBELLACK 1992b). Thus, site-specific circumstances determine the profits derived from chemical weed control. In this study, the possibilities for reducing the recommended doses were validated only with phenoxy acid herbicides, but the same approach has been shown to apply also to sulfonylureas (FOGELFORS 1992, JENNÉUS 1992, Junnila, pers. commun.). In fact, tribenuron-methyl applied at a rate of $7 \mathrm{~g}$ product $\mathrm{ha}^{-1}$ in our field experiments (V) provided good weed control, taking into account that $10 \mathrm{~g} \mathrm{ha}^{-1}$ is regarded as a "normal" dose for spring cereals.

The results achieved in the field experiments (IV, V), both in terms of weed control and yield response, hopefully support farmers' considerations towards cost-effective weed control with reduced herbicide doses. Relatively low yield responses to chemical weed control of annual broadleaved weeds were in accordance with results from the weed survey ERVIÖ et al. (1991). The weed infestation levels in the field experiments (III, IV, V) were equal to the infestation in farmers' fields (I, II, ERVIÖ and SALONEN 1987) in terms of weed density, but not always in terms of weed biomass.
ERVIÖ et al. (1991) reported that chemical weed control in spring cereals provided, on average, a 3\% higher crop yield than without herbicides. At the yield level of $3,500 \mathrm{~kg} \mathrm{ha}^{-1}$ this corresponds to a yield gain of $105 \mathrm{~kg} \mathrm{ha}^{-1}$ with a monetary value of FIM 163 for barley (reference net price FIM 1.55 $\mathrm{kg}^{-1}$ ) and FIM 226 for wheat (FIM $2.15 \mathrm{~kg}^{-1}$ ). The profit would be sufficient to cover the present average herbicide cost of FIM $100 \mathrm{ha}^{-1}$ and even the other costs (machinery, labour) of weed control at least in wheat production.

Based on the results of this study and additional field experiments at the ARC, the Institute of Plant Protection of the ARC in autumn 1993 issued a statement to the Pesticide Commission in Finland, urging revision of the product labels of phenoxyacid herbicides. The reduction of the lowest recommended doses by approximately $30 \%$ was proposed, and moreover, some recommendations for dose-adjustment were suggested to be included on labels.

As herbicides applied in cereal production constitute the majority of herbicides used in Finland, even a slight reduction in their use on individual farms, if practiced by significant numbers of farmers, would lead to considerable savings at the national level. The amount of cereal herbicides sold in 1992 was sufficient to treat 635,000 ha, accounting for $69 \%$ of the total cereal acreage in that year (HYNNINEN and BLOMQVIST 1993), corresponding to a monetary value of approximately FIM 63.5 million in herbicide sales. If the use of these herbicides on a national scale could be reduced by $30 \%$, by adjusting the application rates according to the actual needs, the savings would be approximately FIM 20 million per annum.

A prerequisite for successful long-term reduction in pesticide use is to introduce reliable recommendations and control measures for farmers. The good weed control achieved in the field experiments, with $30 \%$ lower doses than those recommended (V), should encourage farmers to test even lower doses in their own fields. However, the complex factors (management practices, crop rotation, previous weed control) influencing the dynamics of weed populations and survival rates create a complicated environment for decision making. There- 
Table 6. Towards a computerized decision support system for chemical weed control in spring cereal production. Appraisal of the current status of available information in Finland by ranking different factors with a special emphasis on reducing herbicide use.

\begin{tabular}{|c|c|c|}
\hline Factor & $\begin{array}{c}\text { Relative } \\
\text { importance' }\end{array}$ & $\begin{array}{c}\text { Availability } \\
\text { of data }{ }^{2}\end{array}$ \\
\hline
\end{tabular}

a) Factors related to weeds

- Identification of weed species

- Competitive ability of weed species

- Effect of growth stage of weed on susceptibility to herbicides

- Effect of physiological stage of weed on susceptibility to herbicides

- Production of weed seeds in cereals

- Selection in weed population

b) Factors related to herbicides

- Efficacy of individual herbicide against individual weed species

- Effect of dose on efficacy (dose response)

- Effect of weather on efficacy

- Herbicide mixtures

- Adjuvants

- Integration to other control practices

- Sequential application

- Price

- Persistence of herbicides

- Side effects of herbicides

- Toxicology of herbicides

c) Factors related to crop

- Competitiveness of crop

- Competitiveness of crop cultivar

- Prediction of yield loss (quantitative \& qualitative)

- Crops included in crop rotation

d) Factors related to technology

- Software for PC

- Valid weather forecast

- Detection of weed infestation (level, patchiness)

- Sprayer technology (differences between nozzle types etc.)

- Replacement of herbicides with other control practices

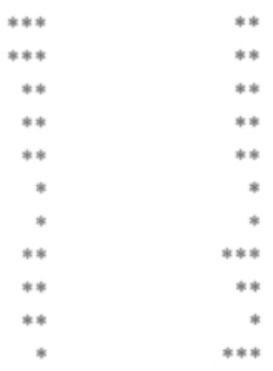

Importance: ***: Essential, **: Intermediate, *: Useful but not necessary to commence

2 Availability: ***: Good data exist, ${ }^{* *}$ : Adequate data to commence but more research required,

*: Finnish (or relevant imported) data inadequate

fore, computerized advisory systems have already been introduced to assist farmers in weed management (e.g. BAANDRUP and BALlEGAARD 1989, GARVERT et al. 1990, FYKSE 1993c).

Introducing the recently obtained results into computerized decision support systems will be the next step in the process of optimizing herbicide use in Finland. The status of available information to develop a decision support system in Finland is summarized in Table 6. Some data (e.g. impact of weather parameters, efficacy, dose response) can in part be adopted from other countries, but further research in Finland is still needed to improve the validity of system. In Denmark one of the most sophisticated PC-based decision support systems is already in use (BAANDRUP and BALLEGAARD 1989, 
MURALI and SECHER 1991), and could be used as a source of data if applicable to Finnish conditions.

Another prospect for applying reduced doses of herbicides is associated with herbicide resistance. Worldwide almost 100 weed species are known to have evolved herbicide resistance, particularly against triazine herbicides used e.g. in maize production (PUTWAIN and MORTIMER 1989). Reports on herbicide (mecoprop and chlorsulfuron) resistant biotypes of Stellaria media (LUTMAN and SNOw 1987, REED et al. 1989, KUDSK et al. 1992) indicate that herbicide resistance is a potential problem for cereal production, too.

Since the development of resistance is suggested to evolve primarily against heavily used, repeatedly used, highly persistent and high-kill herbicides (GRESSEL and SEGEL 1982), the use of low herbicide doses could be an indirect way to delay the development of resistant weed populations. As shown in our experiments, low herbicide doses de- creased the selection pressure of herbicides against many weed species (III, V). Reduced herbicide doses could be intergrated into a strategy together with careful selection of $i$ ) crop rotation, $i i)$ use of herbicide mixtures or a rotation of herbicides and iii) other management practices known to affect weed infestation (SHANER et al. 1992).

Although the overall recommendation of this study promotes continuous use of herbicides in spring cereals with adjusted doses, one-year breaks from herbicide application in circumstances of low weed infestation do not necessarily lead to harmful consequences in terms of yield and the subsequent weed infestation (III, IV, V), particularly in spring barley production. In practice, control measures should primarily be based on the prevailing weed infestation to protect the current crop, as the seasonal changes in weed infestation are not easy to manage or predict (c.f. FIRBANK 1989, FYKSE 1993a).

\section{SUMMARY AND CONCLUSIONS}

Since the 1960 s herbicides, together with improved management practices, have made a considerable contribution to profitable cereal production in Finland. Studies detailed in this thesis on the possibilities of reducing herbicide input in crop production were focused on spring cereals as $i$ ) spring cereals comprise over $50 \%$ of the cultivated field area in Finland, ii) cereals are known to be relatively competitive against weeds and finally, iii) the majority of herbicides in Finland are applied to cereal fields. Therefore, an overall reduction of herbicide use in cereal production would have a significant economic and environmental impact on Finnish cereal production.

Based on the results of the weed survey conducted in 252 fields in southern and central Finland, target weeds for chemical control in spring cereal fields are mainly annual broad-leaved species. The only frequent grass weed was Elymus repens. The weed infestation in unsprayed spring cereal fields averaged 170 plants $\mathrm{m}^{-2}$ (median 124), and air-dry weight $320 \mathrm{~kg} \mathrm{ha}^{-1}$ (median 183). Weed vegetation in individual cereal fields was often dominated by a few species.

Regular weed surveys are needed to follow the responses of weed floras to changes in agricultural practices. Ordination methods proved feasible for analyzing the associations between multispecies weed populations and interrelated environmental factors. Ordination analyses of these data revealed that species composition of weed populations varied regionally and was affected by soil characteristics and crop management practices, particularly by long-term use of herbicides.

Phenoxy acid herbicides are commonly used to control broad-leaved weeds in Finland, and they were found to give sufficient control of the the prevailing weed vegetation, both in terms of yield response and long-term weed infestation. The reduction of weed biomass with MCPA application 
averaged $65 \%$, and with other herbicides (mainly MCPA/dichlorprop or MCPA/mecoprop) $83 \%$.

In the field experiments the weed infestation (No. of plants $\mathrm{m}^{-2}$ ) at the time of herbicide application averaged $72 \%$ of the peak infestation recorded later in the growing season in unsprayed trial plots. However, spraying during the early growth stages of those weeds that emerge in the main flush is recommended, since the competitive ability of the crop is normally sufficient to suppress the growth of late-emerging weed seedlings.

Reduction of the recommended rates of application seldom resulted in a considerable loss in efficacy, detectable yield loss or adverse effect on the subsequent weed infestation. This applied also to the new herbicide mixtures containing optically active isomers of dichlorprop and mecoprop, as well as to sulfonylurea herbicides. Considerable reductions up to $30-50 \%$ of the recommended herbicide doses were often feasible, depending on the herbicide, weed species and the crop. If reduced herbicide doses are to be applied, a precise selection of herbicides according to the weed species composition will be required.

As a consequence of dose reduction, the differential sensitivity of weed species to a particular herbicide became evident. Even so, no drastic changes in weed composition were detected after continous use of reduced herbicide application rates for three years. The species composition of weed populations was affected more by crop rotation than by herbicide type and dose.

Weed biomass frequently comprised less than $5 \%$ of the total vegetative biomass of the crop stands. Consequently, the impact of weeds on crop yield was often very minor even in untreated plots, and statistically significant yield responses to herbicide treatments were seldom detected. There were a number of fields where the yield benefit did not cover the total cost of chemical weed control. Yield responses to herbicide dose proved to be low and this suggests that herbicide inputs in spring cereal production could be minimized.

Since the dose adjustment proved to be sitespecific, the responsibility for the final control result should be transferred from the agrochemical companies and authorities to farmers. After all, farmers are responsible for timing and accuracy of herbicide application and for maintaining their spray-equipment. Computerized advisory systems provide a novel way to assist farmers in decision making. The present study provided valuable data for development of this type of advisory system suited to Finnish growing conditions.

Threshold strategies based on weed densities proved to be inadequate for describing crop-weed interactions in Finnish spring cereal fields. Therefore, before recommending seasonal breaks in the use of herbicides, precision of thresholds has to be improved to minimize decision failures in weed control. Meanwhile, continuous use of herbicides with site-adjusted doses is suggested for spring cereal production.

According to the results of this study, a realistic target should be $30 \%$ reduction in use of herbicides at the national level. Implementation of such a reduction in Finland would correspond, at the current level of herbicide sales, to savings of approximately FIM 20 million per annum. The level and the means of reduction suggested may not alleviate the public disquiet over the use of pesticides, but rather are meant to represent a reliable recommendation for sustainable weed management. 


\section{REFERENCES $^{1)}$}

AAMISEPP, A. 1984. Behovsprövad ogräsbekämpning i vårsäd. Slutrapport. Proc. 25:e svenska ogräskonferensen, Ogräs och ogräsbekämpning. Rapp. p. 33-47.

— \& W ALLGREN, B. 1979. Ogräs i stråsäd. Verkan av kemisk ogräsbekämpning och andra odlingsåtgärder, 1950-1978. Akt. från Lantbr.univ. 280. Uppsala. 15 p.

Albrecht, H. \& Bachthaler, G. 1988. Die Segetalflora zweier bayerischer Ackerstandorte 1986/87 im Vergleich zu Untersuchungsergebnissen von 1955/56 bzw. 1965. Z. Pfl.krankh. Pfl.schutz, Sonderh. 11: 163-174.

Andersson, B. 1984. Utsädesmängder och MCPA-doser i vårkom. Proc. 25:e svenska ogräskonf., Ogräs och ogräsbekämpning. Rapp. p. 49-58.

- 1986. Influence of crop density and spacing on weed competition and grain yield in wheat and barley. Proc. EWRS Symp. Economic Weed Control. p. 121-128.

ANDREASEN, C. 1990. Ukrudtsartemes forekomst på danske sædskiftemarker. Summary: The occurrence of weed species in Danish arable fields. The Royal Vet. and Agric. Univ., Copenhagen. 53 p. (Diss.).

-, HaAs, H. \& Streibig, J.C. 1989. Floraændringer, foreløbig status. Proc. 6. Danske Plantev.konf. Ukrudt. p. 125-133.

—, Streibig, J.C. \& HaAs, H. 1991. Soil properties affecting the weed distribution of 37 weed species in Danish fields. Weed Res. 31: 181-187.

Assémat, L. 1992. Stability of crop and weed growth rates. Proc. IXème Colloque Int. sur la Biologie des Mauvaises Herbes, Dijon. p. 361-367.

Auld, B.A. \& TisDel., C.A. 1988. Influence of spatial distribution of weeds on crop yield loss. Plant Prot. Quart. 3: 81.

BaAndrup, M. \& BallegandD, T. 1989. Three years field experience with an advisory computer system applying factor-adjusted doses. Proc. Brighton Crop Prot. Conf. Weeds. 2: 555-560.

BaChtHAler, G. 1969. Entwicklung der Unkrautflora in Deutschland in Abhängigkeit von den veränderten Kulturmethoden. Angew. Bot. 43: 59-69.

BAYER 1992. Important crops of the world and their weeds. 2nd ed. BAYER AG. Leverkusen. 1681 p.

BEER, E. 1979. Ermittlung der Bekämpfungsschwellen und wirtschaftlichen Schadensschwellen von monokotylen und dikotylen Unkräutem in Winterweizen und Wintergerste anhand von Daten aus der amtlichen Mittelprüfung. Univ. Göttingen. 139 p. (Diss.).

BEHRENDT, S. 1986. Einige Gedanken zur Unkrautbekämpfung in der Zukunft. Proc. EWRS Symp. Economic Weed Control. p. 407-417.

1) Several papers referred to in the introductory chapter and in the original articles have been printed in the symposium proceedings of the European Weed Research Society (EWRS). Proceedings are available from: CABO/ DLO, Dept. Weed Sci., Bornsesteeg 65, NL-6700 Wageningen, The Netherlands.
Bernson, V. 1988. Regulation of pesticides in Sweden. Proc. Brighton Crop Prot. Conf. - Pests and Diseases. 3: 1059 . 1064.

BEYER, E.M. 1991. Crop protection - meeting the challenge. Proc. Brighton Crop Prot. Conf. - Weeds. 1: 3-22.

BIRKs, H.J.B. \& Austin, H.A. 1992. An annotated bibliography of canonical correspondence analysis and related constrained ordination methods 1986-1991. Univ. Bergen, Norway. 29 p.

Bleiholder, H. \& NuYKen, W. 1986. Neue Ansätze zur Darstellung und Interpretation des Zusammenhanges zwischen dem Deckungsgrad der Unkräuter und dem Ertrag von Getreide. Proc. EWRS Symp. Economic Weed Control. p. 61-68.

Callauch, R. 1981. Vergleich der Segetalvegetation auf 'konventionell' und 'biologisch' bewirtschafteten Äckern in SO-Niedersachsen. Z. Pfl.krankh. Pfl.schutz, Sonderh. 9: 85-95.

Catizone, P., Tedeschi, M. \& Baldoni, G. 1990. Influence of crop management on weed populations and wheat yield. Proc. EWRS Symp. Integrated Weed Management in Cereals. p. 119-125.

Chancellor, R.J. 1985. Changes in the weed flora of an arable field cultivated for 20 years. J. Appl. Ecol. 22: 491-501.

Christensen, S. 1993. Weed suppression in cereal varieties. Statens Planteavlforsøk. SP rapport Nr. 1/93. 104 p. (Diss.).

—, Streibig, J.C. \& HaAs, H. 1990. Interaction between herbicide activity and weed suppression by spring barley varieties. Proc. EWRS Symp. Integrated Weed Management in Cereals. p. 367-374.

CombelLaCK, J.H. 1992a. The importance of weeds and ways of reducing concems about methods for their control. Proc. First Int. Weed Control Congr., Melbourne. 1: 4363.

- 1992b. An appraisal of opportunities to reduce herbicide use. Crop Prot. Quart. 7: 66-69.

Courtney, A.D. 1991. The role of competition in developing an appropriate rate strategy for weed control in spring barley. Proc. Brighton Crop Prot. Conf. - Weeds. 3: 1217-1224.

— \& Johnston, R.T. 1986. An assessment of weed populations and yield responses on spring barley subjected to a programme of reduced herbicide usage. Proc. EWRS Symp. Economic Weed Control. p. 301-308.

Cousens, R., Brain, P., O'Donovan, J.T. \& O'Sullivan, A. 1987. The use of biologically realistic equations to describe the effects of weed density and relative time of emergence on crop yield. Weed Sci. 35: 720-725.

Cussans, G.W. 1980. Strategic planning for weed control - a researcher's view. Proc. 1980 Brit. Crop Prot. Conf. Weeds. 3: 823-831.

- 1992. Identifying ways of optimizing herbicide use in crops. Proc. First Int. Weed Control Congr., Melbourne. 1: 208-214. 
-, Cousens, R.D. \& Wilson, B.J. 1986. Thresholds for weed control - the concepts and their application. Proc. EWRS Symp. Economic Weed Control. p. 253-260.

—, Moss, S.R., Pollard, F. \& Wilson, B.J. 1979. Studies on the effects of tillage on annual weed populations. Proc. EWRS Symp. Influence of Different Factors on the Development and Control of Weeds. p. 115-122.

Dale, M.R.T. \& Thomas, A.G. 1987. The structure of weed communities in Saskatchewan fields. Weed Sci. 35: 348355 .

—, Tномаs, A.G. \& Joнn, E.A. 1992. Environmental factors including management practices as correlates of weed community composition in spring seeded crops. Can. J. Botany. 70: 1931-1939.

Davies, D.H.K., Proven, M.J., Courtney, A.D. \& Lawson, H.M. 1993. Comparison of the use of weed thresholds and routine herbicide use at reduced rate on the economics of cereal production in the rotation. Proc. 8th EWRS Symp. Quantitative Approaches in Weed and Herbicide Research. 2: 747-754.

—, Whiting, A.J. \& Wнүтоск, G.M. 1989. Yield responses to herbicide use and weed levels in winter wheat and spring barley in Scottish trials and consequences for economic models. Proc. Brighton Crop Prot. Conf. Weeds. 3: 955-960.

DeBaEkE, P. 1988. Dynamique de quelques dicotylédones adventices en culture de céréale. II. Survie, floraison et fructification. Weed Res. 28: 265-279.

- 1990. Effets de systemes de culture diversement intensifies sur la composition et la dynamique de la flore adventice des cereales d'hiver. Proc. EWRS Symp. Integrated Weed Management in Cereals. p. 143-152.

DEvine, M.D. 1988. Environmental influences in herbicide performance: A critical evaluation of experimental techniques. Proc. EWRS Symp. Factors Affecting Herbicidal Activity and Selectivity. p. 219-226.

Dock Gustavsson A.-M. 1986. Relative growth rate and competitive ability of annual weeds. Proc. EWRS Symp. Economic Weed Control. p. 105-112.

Edwards, C.A. \& RegniER, E.E. 1989. Designing integrated low-input farming systems to achieve effective weed contol. Proc. Brighton Crop Prot. Conf. - Weeds. 2: 585-590.

Eggers, T. 1984. Wandel der Unkrautvegetation der Äcker. Proc. 44. Deutsche Pfl.sch.-Tagung. Mitt. Biol. Bundesanst. Land- u. Forstw. Heft 223: 62.

- 1987. Environmental impact of chemical weed control in arable fields in the Federal Republic of Germany. Proc. 1987 Brit. Crop Prot. Conf. - Weeds. 1: 267-275.

ELııтt, J.G. 1978. The economic objectives of weed control in cereals. Proc. 1978 Brit. Crop. Prot. Conf. - Weeds. 3: 829-841.

EngSTROM, E. 1978. Control of dicots in spring cereals with MCPA, MCPA+dichlorprop and different doses of Oxytril 4. Proc. 19th Swed. Weed Conf. - Weeds and Weed Control. p. B58-B68.

ERviö, L.-R. 1981. The emergence of weeds in the field. Ann. Agric. Fenn. 20: 292-303.

- 1983. Competition between barley and annual weeds at different sowing densities. Ann. Agric. Fenn. 22: 232239.

— \& Hırvol.A, S.-L. 1986. Herbisidien käytön vähentäminen viljakasvustoissa. Maatalouden tutkimuskeskus, Tiedote 8/86. p. $28-42$.

— \& SAlONEN, J. 1987. Changes in the weed population of spring cereals in Finland. Ann. Agric. Fenn. 26: 201-226.

-, Tanskanen, T. \& Salonen, J. 1991. Profitability of chemical weed control in spring cereals. Ann. Agric. Fenn. 30: 199-206.

ESPEBY, L. 1989. Germination of weed seeds and competition in stands of weed and barley. Crop Prod. Sci. 6. Uppsala, Sweden. 172 p. (Diss.).

Evans, S.A. 1968. Project N.A.E. 30 - Results and conclusions. Proc. 9th Brit. Weed Contr. Conf. 3: 1165-1166.

FIRBANK, L.G. 1989. Forecasting weed infestations - the desirable and the possible. Proc. Brighton Crop Prot. Conf. - Weeds. p. 567-572.

Fogelfors, H. 1974. Några ogräsarters utveckling under skilda ljusföhållanden och konkurrensförmåga i kornbestånd. Lantbr.högsk. Inst. Växtodl., Uppsala. 74 p.

— 1979. Floraförändringar i odlingslandskapet. Sveriges Lantbr.univ. Inst. Ekol. and Miljöv., Rapp. 5. 66 p.

- 1990. Different doses of herbicide for control of weeds in cereals - final report from the long-term series. Proc. 31st Swedish Crop Prot. Conf. p. 139-151.

- 1992. Erfarenheter från försöksverksamheten med dosnycklar. Proc. 33:e svenska växtskyddskonferensen, Ogräs och ogräsbekämpning. Rapp. p. 13-20.

Froud-Williams, R.J., Drennan, D.S. \& Chancellor, R.J. 1983. Influence of cultivation regime on weed floras of arable cropping systems. J. Appl. Ecol. 20: 187-197.

FRYER, J.D. \& CHANCELlor, R.J. 1970. Evidence of changing weed populations in arable land. Proc. 10th British Weed Control Conf. 3: 958-964.

FYKSE, H. 1991a. Skadetersklar for ugras. Norsk Landbr.forskn., Suppl. 10: 40-43.

- 1991b. Skadetersklar for ugras i vårkorn. Informasjonsmøte i plantevern 1991. Faginfo 2/93. p. 165-173.

- 1993a. Dynamics of weeds in long-term experiments in spring cereals. Proc. EWRS Symp. Quantitative Approaches in Weed and Herbicide Research. 2: 689-696.

— 1993b. Ugrassituasjonen i vårkorn ved ulike bekjempningsstrategier. Informasjonsmøte i plantevern 1993. Faginfo 3/93. p. 172-180.

— 1993c. Råd via TELEVIS om sprøyting mot ugras. Informasjonsmøte i plantevern 1993. Faginfo 3/93. p. 143146.

GARBURG, W. 1974. Untersuchungen zur Ermittlung der ökonomischen Schadensschwellen und der Bekämpfungsschwellen von Unkräutern in Getreide. Univ. Göttingen. 133 p. (Diss.).

Garvert, U., Wagner, J., Kochs, H.J., Heyland, K.U. \& STEETS, R. 1990. HERBEXPERT - ein computergestütztes System zur schlagspezifischen Herbizidberatung im Getreidebau. Z. Pfl.krankh. Pfl.schutz, Sonderh. 12: 191195.

GAUCH, H.G. 1982. Multivariate analysis in community ecology. Cambridge University Press, Cambridge. 298 p. 
GEROwTT, B. 1992. Dreijährige Versuche zur Anwendung eines computergestützten Entscheidungsmodells zur Unkrautbekämpfung nach Schadensschwellen im Winterweizen. Z. Pfl.krankh. Pfl.schutz, Sonderh. 13: 301-310.

-, Bodendórfer, H. \& Hertefuss, R. 1984. Zur Wirtschaftlichkeit des Herbizideinsatzes im Getreide Auswertung von Versuchen des Pflanzenschutzdienstes den Jahren 1977-81. Z. Pfl.krankh. Pfl.schutz, Sonderh. 10: 127-135.

— \& Hertefuss, R. 1990. Weed economic thresholds in cereals in the Federal Republic of Germany. Crop Prot. 9; 323-331.

— , Hertefuss, R., Fischer, A. \& Reiner, L. 1986. Versuche zur Erarbeitung von Kriterien für EDV-gestützte Enscheidungshilfen zur Unkrautbekämpfung nach Schadensschwellen im Wintergetreide. Proc. EWRS Symp. Economic Weed Control. p. 351-360.

GRANSTRÖM, B. 1962. Studier över ogräs i vårsådda grödor. Kungl. Lantbr.högsk. och St. Lantbr.försök, Medd. Nr. 130, Uppsala. 188 p.

— \& AlmgÃRd, G. 1955. Studier över den svenska ogräsfloran. Stat. Jordbr.försök, Meddel. nr 56. 22 p.

Gressel, J. \& SEGEl, L.A. 1982. Interrelating factors controlling the rate of appearance of resistance: the outlook for the future. In: LeBaron, H.M. \& Gressel, J. (eds.). Herbicide resistance in plants. J. Wiley \& Sons. p. 325-347.

Gummesson, G. 1975. Ogräsförekomsten i stråsäd. Proc. 16:e svenska ogräskonf. Ogräs och ogräsbekämpn. 1. Föredrag. p. K21-K37.

— \& Fogelfors, H. 1990. Möjligheter till minskad bekämpning av ogräs i stråsäd. Proc. 31:a svenska växtskyddskonf., Skadedj. och Växtsjukd. p. 60-68.

HaAs, H. \& Streibig, J.C. 1982. Changing patterns of weed distribution as a result of herbicide use and other agronomic factors. In: LeBaron, H.M. \& Gressel, J. (eds.). Herbicide resistance in plants. J. Wiley \& Sons. p. 57-79.

HĂKAnSSON, S. 1975. Grundläggande växtodlingsfrågor. I. Inflytande av utsädesmängden och utsädets horisontella fördelning på utveckling och produktion i kortvariga växtbestånd. Sveriges Lantbr.univ, Rapp. o. Avhandl. 33. Uppsala. 192 p.

- 1983a. Seasonal variation in the emergence of annual weeds - an introductory investigation in Sweden. Weed Res. 23: 313-324.

- 1983b. Competition and production in short-lived cropweed stands. Swed. Univ. Agric. Sci., Dept. Plant Husb., Report 127. Uppsala. 85 p.

- 1986. Competition between crops and weeds - influencing factors, experimental methods and research needs. Proc. EWRS Symp. Economic Weed Control. p. 49-60.

- 1991. Growth and competition in plant stands. Swedish Univ. Agric. Sci., Crop Prod. Sci. No 12. Uppsala. 241 p.

- 1992. Germination of weed seeds in different seasons. Proc. IXe Colloque Int. sur la Biologie des Mauvaises Herbes, Dijon. p. 45-54.

Hallgren, E. 1988. Influence of different factors on the effect of spraying cereals in the spring with Oxitril 4 as regards weeds and grain yield. 2 . Influence of crop, de- velopmental stage, prevailing conditions, geographical and climatic situation, soil type, organic content and $\mathrm{N}$-rate on weed stand and effect on weeds. Composition of weed stand at different relative yields. Proc. 29th Swedish Weed Contr. Conf., Weeds and Weed Control. p. 39-74.

- 1993a. Förändras ogräsfloran och verkan av ett ogräsmedel (Oxitril 4) med tiden. Proc. 34:e svenska växtskyddskonferensen, Ogräs och ogräsbekämpn. Rapp. p. 15-38,

— 1993b. Verkan av några ogräsmedel mot olika tvåhjärtbladiga ogräsarter vid skilda doser och behandlingstidpunkter. Summary: Effects of some herbicides or mixtures of herbicides on individual dicot weed species at different doses and developmental stages. Sver. Lantbr.univ. Växtodling 44. Uppsala. 85 p.

Hämet-Ahti, L., Suominen, J., Ulvinen, T., Uotila, P. \& Vuокко, S. (eds.). 1984. Retkeilykasvio. Suomen Luonnonsuojelun Tuki, Helsinki. 544 p.

HanCE, R.J. \& Holly, K. (eds.). 1990. Weed control handbook: Principles. Brit. Crop Prot. Council, Blackwell Sci. Publ. 582 p.

Herteruss, R. 1986. Auswirkungen von Unkräutern und Massnahmen der Unkrautbekämpfung auf andere Kriterien als den Ertrag. Proc. EWRS Symp. Economic Weed Control. p. 189-199.

—, Gerowitt, B. \& W WhмноF, W. 1987. Development and implementation of weed economic thresholds in the F.R. Germany. Proc. Brit. Crop Prot. Conf. - Weeds. 3: 10251034.

HiLL, M.O. 1973. Reciprocal averaging: an eigenvector method of ordination. J. Ecol. 61: 237-249.

— \& GAUCH, H.G. 1980. Detrended correspondence analysis, an improved ordination technique. Vegetatio 42: 47-58.

Hillı, A. 1948. Rikkaruohomme ja niiden taloudellinen merkitys. Maatal. ja Koetoim. 3: 154-168.

HinTZSCHE, E. 1990. Zur Wirkung acker- und pflanzenbaulicher Massnahmen auf einzelne Unkrautarten bzw. Unkrautartengruppen. Z. Pfl.krankh. Pfl.schutz, Sonderh. 12: 211-218.

Holm, L.G., Plucknett, D.L., Pancho, J.V. \& Herberger, J.P. 1977. The world's worst weeds, distribution and biology. The Univ. Press of Hawaii, Honolulu. 609 p.

Holzner, W. \& Immonen, R. 1982. The agrestal weed flora and vegetation of the world: examples and aspects, Europe: an overview. In: Holzner, W. \& Numata, M. (eds.). Biology and ecology of weeds. Dr. W. Junk Publ., The Hague. p. 203-226.

HoRNIG, H. 1972. Unkrautbekämpfung mit reduzierten Aufwandmengen in Getreide. Gesunde Pfl. 24: 145-150.

Hughes, R.G. 1966. Project N.A.E. 30 "The efficiency of weed control in cereals on commercial farms". Proc. 8th Brit. Weed Control Conf. p. 200-205.

Hume, L. 1987. Long-term effects of 2,4-D application on plants. I. Effects on the weed community in a wheat crop. Can. J. Botany 65: 2530-2536.

HurLe, K. 1974. Effects of long-term weed control measures on viable weed seeds in the soil. Proc. British Crop Prot. Conf. - Weeds. 3: 1145-1152. 
Hynninen, E.-L. \& Blomevist, H. 1991. Torjunta-aineiden myynti Suomessa. [Summary: Sales of pesticides in Finland in 1990]. KemiaKemi 18: 506-509.

— \& Blomevist, H. 1992. Pesticide sales in Finland in 1991. Kemia-Kemi 19: 563-565.

— \& Blompvist, H. 1993. Pesticide sales in Finland 1992. Kemia-Kemi 20: 535-537.

JENNÉUS, B. 1992. Erfarenheter från ogräsbekämpning i demonstrationsodlingar med hjälp av dosnycklar. Proc. 33:e svenska växtskyddskonferensen, Ogräs och ogräsbekämpning. Rapp. p. 21-32.

Jensen, P.K. 1985. A review of yield responses to weed control in one thousand spring barley experiments. Proc. British Crop Prot. Conf. - Weeds. 2: 687-692.

— 1987. Skadetærskler for tokimbladet ukrudt i vårbyg. Tidsskr. Planteavl. 90: 369-376.

- 1991a. Weed size hierarchies in Denmark. Weed Res. 31: 1-7.

— 1991b. Behov og økonomi ved ukrudtsbekæmpelse i landbrugsafgrøder. Bilag til Møder om plantevern 1991, Landbrugsafgrøder. p. 14-16.

JOKINEN, K. 1991. Competition and yield advantage in barley-barley and barley-oats mixtures. J. Agric. Sci. Finl. 63: 255-284. (Diss.).

Jongman, R.H.G., Ter Braak, C.J.F. \& Van Tongeren, O.F.R. 1987. Data analysis in community and landscape ecology. Pudoc, Wageningen. 299 p.

JUNNILA, S. 1990. Influence of spraying time on herbicide efficacy in spring cereals. Proc. EWRS Symp. Integrated Weed Management in Cereals. p. 375-382.

- 1993. Över 10-års försöksarbete med S.U.-herbicidema i Finland. Proc. DuPont-seminarium i Stockholm. Mimeogr. 8 p. (Available at the Agric. Res. Centre of Finland, Jokioinen).

Kallio-Mannila, K., Raatikainen, T. \& Raatikainen, M. 1984. Rikkaruohot vähentyneet - torjuntaa muutettava. Koetoim. ja Käyt. 41: 53.

KEES, H. 1986. Einfluss zehnjähriger Unkrautbekämpfung mit 4 unterschiedlichen Intensitätsstufen unter Berücksichtigung der wirtschaftlichen Schadensschwelle auf Unkrautflora und Unkrautsamenvorrat im Boden. Proc. EWRS Symp. Economic Weed Control. p. 399-406.

Kirby, E.J.M., Siddique, K.H.M., Perry, M.W., Kaeseha. GEN, D. \& STERN, W.R. 1989. Variation in spikelet initiation and ear development of old and modern Australian wheat varieties. Field Crops Res. 20: 113-128.

KNAB, W. \& HuRle, K. 1986. Einfluss der Grundbodenarbeitung auf die Verunkrautung - ein Beitrag zur Prognose der Verunkrautung. Proc. EWRS Symp. Economic Weed Control. p. 309-316.

Korsmo, E. 1925. Ugress i nutidens jordbruk. J.W. Cappelens forlag. Oslo. 694 p.

KROPFF, M.J. 1988. Modelling the effects of weeds on crop production. Weed Res. 28: 465-471.

— \& SPrTters, C.J.T. 1991. A simple model of crop loss by weed competition from early observations on relative leaf area of the weed. Weed Res. 31: 97-105.

KUDSK, P. 1989. Experiences with reduced herbicide doses in Denmark and the development of the concept of factor- adjusted doses. Proc. Brighton Crop Prot. Conf. - Weeds. 2: 545-554.

— \& KRISTEnSEN, J.L. 1992. Effect of environmental factors on herbicide performance. Proc. First Int. Weed Contr. Congr., Melbourne. 1: 173-186.

—, Mathiasen, S.K. \& Petersen, E.F. 1992. Sulfonylurearesistens i fuglegræs. Proc. 9. Danske Plantev.konf., Ukrudt. p. 147-156.

Lawson, H.M., Wright, G.McN., Davies, D.H.K. \& WhitING, A.J. 1992. The effects of reduced herbicide strategies on the weed flora in cereals in Scotland: an interim report. Proc. IXe Colloque Int. sur la Biologie des Mauvaises Herbes, Dijon. p. 269-278.

LeBaron, H.M. \& Gressel, J. (eds.). 1982. Herbicide resistance in plants. John Wiley \& Sons, Inc. New York. $401 \mathrm{p}$.

Légére, A., Lemieux, C., Simard, R.R. \& Lapierre, C. 1993. Response of weed communities to fertility and tillage. Proc. 8th EWRS Symp. Quantitative Aspects of Weed and Herbicide Research. p. 41-48.

—, Samson, N., Lemieux, C. \& Rioux, R. 1990. Effects of weed management and reduced tillage on weed populations and barley yields. Proc. EWRS Symp. Integrated Weed Management in Cereals. p. 111-118.

Littell, R.C., Freund, R.J. \& Spector, P.C. 1991. SAS® System for Linear Models, 3rd Edit. SAS Institute Inc. Cary, NC. 329 p.

LOMAKKA, L. 1990. Minimerad kemisk bekämpning av ogräs vid ensidig kornodling i Norra Sverige. Proc. 31:a svenska växtskyddskonferensen, Ogräs och ogräsbekämpning. Rapp. p. 27-38.

Lotz, L.A.P., KropfF, M.J. \& Groeneveld, R.M.W. 1990. Modelling weed competition and yield losses to study the effect of omission of herbicides in winter wheat. Neth. J. Agric. Sci. 38: 711-718.

-, KropfF, M.J. \& Groeneveld, R.M.W. 1993. The relative leaf cover model tested for practice. Proc. 8th EWRS Symp. Quantitative Aspects of Weed and Herbicide Research. 2: 793-798.

Lutman, P.J.W. 1992. Prediction of the competitive effects of weeds in the yields of several spring-sown arable crops. Proc. IXe Colloque Int. sur la Biologie des Mauv. Herbes, Dijon. p. 337-344.

— \& SNOw, H.S. 1987. Further investigations into the resistance of Chickweed (Stellaria media) to mecoprop. Proc. 1987 British Crop Prot. Conf. - Weeds. 3: 901908.

Maнn, E.G. 1984. The influence of different nitrogen levels on the productivity and structural changes of weed communities in agroecosystems. Proc. 7th Int. Symp. on Weed Biology and Systematics, Paris. p. 421-429.

- 1992. Ackerunkräuter - ihre bedeutung im Agro-Ökosystem aus ökologischer Sicht. Z. Pfl.krankh. Pfl.schutz, Sonderh. 12: 21-30.

- \& HelmeCKE, K. 1979. Effects of herbicide treatment on the structure and functioning of agro-ecosystems: II. Structural changes in the plant community after the application of herbicides over several years. AgroEcosyst. 5: 159-179. 
Markilla, M., Titttanen, K. \& Vasarainen, A. 1990. Torjunta-aineet maa- ja metsätaloudessa 1953-1987. Maatalouden tutkimuskeskus, Tiedote 2/90. 58 p.

MarShall, E.J.P. 1988. Field-scale estimates of grass weed populations in arable land. Weed Res. 28: 191-198.

MeINLSCHMIDT, E. \& KaRCH, K. 1992. Weed growth suppression by means of repeated applications of reduced herbicide doses. Proc. IXe Colloque Int. sur la Biologie des Mauvaises Herbes, Dijon. p. 369-376.

Mela, T. \& PAAtel.A, J. 1974. Grain yield of spring wheat and oats as affected by population density. Ann. Agric. Fenn. 13: 161-167.

Miknelsen, V.M. \& Laursen, F. 1966. Markukrudtet i Danmark omkring 1960. Botan. Tidsskr. 62: 1-26.

Ministry of Agriculture 1990. Multi-year crop protection plan. Essentials, Min. Agric., Dept. Nature Management and Fisheries, Amsterdam. 14 p.

Morgan, W. 1992. Strategies to reduce dependence on herbicides. Proc. First Int. Weed Contr. Congr., Melbourne. 1: 289-294.

Moss, S.R. 1985. The influence of crop variety and seed rate on Alopecurus myosuroides competition in winter cereals. Proc. Brit. Crop. Prot. Conf. - Weeds. 2: 701-708.

Mukula, J. 1974. Weed competition in spring cereals in Finland. Forskn. o. Fors. Landbr. 25: 585-592.

—, RaAtikainen, M., LallukKa, R. \& RaAtikainen, T. 1969. Composition of weed flora in spring cereals in Finland. Ann. Agric. Fenn. 8: 59-109.

— \& Rantanen, O. 1987. Climatic risks to the yield and quality of field crops in Finland. I. Basic facts about Finnish field crops production. Ann. Agric. Fenn. 26: 1-18.

— \& RuUtTunen, E. 1969. Chemical weed control in Finland in 1887-1965. Ann. Agric. Fenn. 8, Suppl. 1: 1-45.

Murali, N.S. \& Secher, B.J.M. 1991. Status on the computer-based plant protection systems in Denmark. Proc. Workshop on computer-based plant prot. advisory systems. Danish J. Pl. and Soil Sci. - Spec. series, Report no. S 2161. p. 7-10.

Neururer, H. 1976. Ökonomische Schadensschwelle und tolerierbare Verunkrautungsstärke in der Unkrautsbekämpfung. Land u. Forstw. Forsch. in Österreich, Band 7: 143-152.

NiemanN, P. 1990. Zur Häufigkeit von Bestandeslücken und deren Bedeutung für die Verunkrautung. Z. Pfl.krankh. Pfl.schutz, Sonderh. 12: 59-69.

PAATEl.A, J. 1953. Maamme heinänurmien botaanisesta koostumuksesta. Summary: On the botanical composition of the tame-hayfields in Finland. Acta Agr. Fenn. 79: 1-128.

PAllutT, B. 1988. Beträge zur integrierten Unkrautbekämpfung im Getreideanbau. Akad. Landw. der DDR, Berlin. 129 p. (Diss.).

— \& RoDeR, W. 1992. Zur Verbesserung der Vorhersagegenauigkeit von unkrautbedingten Kornertragsverlusten bei Wintergetreide. Z. Pfl.krankh. Pfl.schutz, Sonderh. 13: 129-137.

Pedersen, H.E. 1978. Use of reduced doses of herbicides in barley. Proc. 19th Swedish Weed Control Conf., Weeds and Weed Control. p. B43-B49.
Pedersen, J.O. \& Rasmussen, I.A. 1990. Herbiciders inflydelse på ukrudets fröproduktion. Proc. 7. Danske Plantev.konf, Ukrudt. p. 73-83.

Peltonen-Sainio, P. \& Järvinen, P. 1993. Effects of seeding rate on growth duration and accumulation and partitioning of dry-matter in oats. Mimeogr. (Available at the Inst. Crop Sci., Univ. of Helsinki).

Petersen, H.I. 1943. Undersøgelser over Ukrudstarter i Rugmarken. Ugeskr. for Landm. 88: 492-497.

Post, B.J. 1986. Factors of influence on the development of an arable weed vegetation. Proc. EWRS Symp. Economic Weed Control. p. 317-325.

Proven, M.J., Courtney, A., Picton, J., Davies, D.H.K. \& Whiting, A.J. 1991. Cost-effectiveness of weed control in cereals - systems based on thresholds and reduced rates. Proc. Brighton Crop Prot. Conf. - Weeds. 3: 12011208.

Putwain, P.D. \& Mortimer, A.M. 1989. The resistance of weeds to herbicides: rational approaches for containment of a growing problem. Proc. Brighton Crop Prot. Conf. Weeds. 1: 285-294.

RAatikainen, M. \& RaAtikainen, T. 1975. Heinänurmien sato, kasvilajikoostumus ja sen muutokset. Summary: Yield, composition and dynamics of flora in grassland for hay in Finland. Ann. Agric. Fenn. 14: 57-191.

—, RaAtikainen, T. \& Mukula, J. 1978. Weed species, frequencies and densities in winter cereals in Finland. Ann. Agric. Fenn. 17: 115-142.

RADEMACHER, B. \& КосH, W. 1972. Kulturanbedingte Veränderungen in der Unkrautflora eines Feldes von 1956 bis 1971. Z. Pfl.krankh. Pfl.schutz, Sonderh. 6: 149-160.

-, Koch, W. \& Hurle, K. 1970. Changes in the weed flora as the result of continuous cropping of cereals and the annual use of the same weed control measures since 1956. Proc. 10th Brighton Weed Conf. p. 1-6.

RASMUSSEN, I.A. 1993. Seed production of Chenopodium album in spring barley sprayed with different herbicides in normal to very low doses. Proc. EWRS Symp. Quantitative Approach in Weed and Herbicide Research. 2: 639-646.

Reed, W.T., Saladini, J.L., Cotterman, J.C., Primiani, M.M. \& SAARI, L.L. 1989. Resistance in weeds to sulfonylurea herbicides. Proc. Brighton Crop Prot. Conf. - Weeds. 1: 295-300.

Reuss, H.-U. 1981. Untersuchung des Einflusses produktionstechnischer und ökologischer Faktoren auf die quantitative und qualitative Veränderung der standörtlichen Unkrautflora auf Ackerland. Technischen Universität München. 116 p. (Diss.).

Richards, M.C. 1989. Crop competitiveness as an aid to weed control. Proc. Brighton Crop Prot. Conf. - Weeds. 2: 573-578.

— \& Davies, D.H.K. 1991. Potential for reducing herbicide inputs/rates with more competitive cereal cultivars. Proc. Brighton Crop Prot. Conf. - Weeds. 3: 1233-1240.

ROBERTS, H.A. \& PotTER, E.M. 1980. Emergence patterns of weed seedlings in relation to cultivation and rainfall. Weed Res. 20: 377-386. 
SALONEN, J. 1992a. Viljanviljelyn kannattava rikkakasvintorjunta. Maataloustieteen päivät. Suomen Maatal.tiet. seur. tied. No 16. p. 60-67.

- 1992b. Distribution of nitrogen between crop and weeds in spring cereals. Acta Agric. Scand., Sect B, Soil and Plant Sci. 42: 218-223.

- 1993. Dynamics of weed infestation in spring cereals with special reference to the use of reduced herbicide doses. Proc. 8th EWRS Symp. Quantitative Approaches in Weed and Herbicide Research. 2: 715-722.

— \& ERvio, L.-R. 1988. Changes in the weed infestation of spring cereals in Finland between the 1960's and 1980's. Proc. VIIle Colloque Int. sur la biologie, l,écologie et la systématique des Mauvaises Herbes, Dijon. p. 439-444.

SAS Institute Inc. 1985. SAS® User's Guide: Basics, Vers. 5 ed. SAS Inst. Inc. Cary, NC. 1290 p.

- 1990. SAS/STAT® User's Guide, Vers. 6, 4th ed., Vol 2. SAS Inst. Inc. Cary, NC. 848 p.

SCragG, E.B. 1980. Cost-effective weed control in spring barley in the north of Scotland. Proc. British Crop Prot. Conf. - Weeds. 1: 69-76.

Shaner, A., Sinha, A. \& Braddock, R. 1992. Designing strategies to delay development of resistance to herbicides. Proc. First Int. Weed Control Congr., Melbourne. 1: 236-239.

ŠMILAUER, P. 1990. CANODRAW - a companion program to CANOCO for publication-quality graphical output. Microcomputer Power, Ithaca, New York. 33 p.

Speranza, M., Govi, G. \& Catizone, P. 1990. Crop management and weed flora of cereals in Italy. Proc. EWRS Symp. Integrated Weed Management in Cereals. p. 163171.

Sptrters, C.J.T. \& VAN Den Bergh, J.P. 1982. Competition between crop and weeds: A system approach. In: Holzner, W. \& Numata, M. (eds.). Biology and ecology of weeds. Dr. W. Junk Publ., The Hague. p. 137-148.

Squires, N.R.W., RadTKE, M. \& Hunt, S. 1987. New formulations of phenoxypropionic herbicides containing only the herbicidally active isomer for the control of broadleaved weeds in cereals. Proc. British Crop Prot. Conf. Weeds. 1: 225-231.

STreibIG, J.C. 1979. Numerical methods illustrating the phytosociology of crops in relation to weed flora. J. Appl. Ecol. 16: 577-587.

- 1983. Ukrudtssprøjtning og merudbytte i korn. Ugeskrift for Jordbr. 40: 811-816.

- 1988. Herbicide bioassay. Weed Res. 28: 479-484.

- 1992. Quantitative assessment of herbicide phytotoxicity with dilution assay. Royal Vet. and Agric. Univ. Copenhagen. 98 p. (Diss.).

- , Gottschau, A., Dennis, B., HaAs, H. \& Mølgaard, P. 1984. Soil properties affecting weed distribution. Proc. 7th International Symposium on Weed Biology, Ecology and Systematics, Paris. p. 147-154.

— \& HaAs, H. 1979. Zusammensetzung der dänischen Unkrautflora und deren Veränderung in den letzten 60 Jahren. Proc. EWRS Symp. Influence of Different Factors on the Development and Control of Weeds. p. 273-280.

Stryckers, J.M.T. 1979. Veränderungen in der (Un)kraut- flora durch Herbizidanwendung. Proc. EWRS Symp. Influence of Different Factors on the Development and Control of Weeds. p. 25-38.

Stubsıøen, R. 1991. Ny landbrugspolitikk - Handlingsplan for reduceret bruk av plantevernsmidler. Informasjonsmøte i Plantevern 1991. Faginfo 2/91. p. 23-28.

Ter BRAAK, C.J. 1986. Canonical correspondence analysis: a new eigenvector technique for multivariate direct gradient analysis. Ecology. 67: 1167-1179.

- 1987a. CANOCO - a FORTRAN program for Canonical Community Ordination. Microcomputer Power, Ithaca, New York. 95 p.

- 1987b. Unimodal models to relate species to environment. Agric. Univ. Wageningen. 151 p. (Diss.).

Thomson, W.J. \& Stokes, D.T. 1985. Cereal apex development in relation to crop management. Aspects Appl. Biol. 10: 415-429.

THONKE, K.E. 1978. Influence of growth factors when using reduced doses of hormone herbicides in barley. Proc. 19th Swedish Weed Conf. Weeds and Weed Control. p. B51-B57.

- 1986. Muligheder for anvendelse af reducerede doseringer af herbicider. Proc. 3. Danske Plantev.konf. Ukrudt. p. 117-124.

- 1991. Political and practical approaches in Scandinavia to reduce herbicide inputs. Proc. Brighton Crop Prot. Conf. - Weeds. 3: 1183-1190.

Thornton, P.K., Fawcett, R.H., Dent, J.B. \& Perkins, T.J. 1990. Spatial weed distributions and economic thresholds for weed control. Crop Prot. 9: 337-342.

Tuttanen, K. \& Blomevist, H. 1981. Sales of pesticides in Finland in 1980. Kemia-Kemi 8: 504-506.

TomkIns, D.J. \& GRANT, W.F. 1977. Effects of herbicides on species diversity of two plant communities. Ecology. 58: 398-406.

VAn Groenendael, J.M. 1988. Patchy distribution of weeds and some implications for modelling population dynamics: a short literature review. Weed Res. 28: 437-441.

W Aнмноғ, W. 1990. The use of economic thresholds over a three year period in cereal crop rotations and the effects on weed infestations two years later. Proc. EWRS Symp. Integrated Weed Management in Cereals. p. 323-330.

WARWICK, S. 1991. The influence of intraspecific variation on the biology and control of agricultural weeds. Proc. Brighton Crop Prot. Conf. - Weeds. 3: 997-1006.

WATSON, A.K. 1992. Biological and other alternative control measures. Proc. First Int. Weed Contr. Congr., Melbourne. 1: 64-73.

Whiting, A.J., Davies, D.H.K., Brown, H. \& Whytock, G.P. 1991. The field use of reduced doses of broad-leaved weed herbicides in cereals. Proc. Brighton Crop Prot. Conf. - Weeds. 3: 1209-1216.

Wilson, B.J. 1982. The yield response of winter cereals to autumn or spring control of broad-leaved weeds. Aspects of Appl. Biol. 1. Broad-leaved weeds and their control in cereals. p. 53-61.

- 1986. Yield responses of winter cereals to the control of broad-leaved weeds. Proc. EWRS Symp. Economic Weed Control. p. 75-82. 
— \& Brain, P. 1990. Weed monitoring on a whole farm patchiness and the stability of distribution of Alopecurus myosuroides over ten year period. Proc. EWRS Symp. Integrated Weed Management in Cereals. p. 45-51.

—, Peters, N.C.B., Wright, K.J. \& Atkins, H.A. 1988. The influence of crop competition on the seed production of Lamium purpureum, Viola arvensis and Papaver rhoeas in winter wheat. Aspects Appl. Biol. 18: 71-80.

Wilson, P.J., Boatman, N.D. \& Edwards, P.J. 1990. Strategies for the conservation of the endangered arable weeds in Great Britain. Proc. EWRS Symp. Integrated Weed Management in Cereals. p. 93-101.

Ympäristöministeriö 1992. Ehdotus maaseudun ympäristöohjelmaksi Ympäristönsuoj.os., Työryhmämiet. 68/92. Helsinki. 49 p.
Young, J.A. \& Evans, R.A. 1976. Responses of weed populations to human manipulations of the natural environment. Weed Sci. 24: 186-190.

Zadoks, J.C., Chang, T.T. \& KonzaK, C.F. 1974. A decimal code for growth stages of cereals. Weed Res. 14: 415421.

ZEDDIES, J. 1986. Wirtschaftlichen Bedeutung der Unkrautbekämpfung unter zukunftigen Rahmenbindungen. Proc. EWRS Symp. Economic Weed Control. p. 39-45.

Zwerger, P., Hurle, K. \& Kemmer, A. 1990. Untersuchungen zum Einfluss von Fruchtfolge und Abbauintensität auf die Entwicklung des Unkrautsamenhaltes im Boden. Proc. EWRS Symp. Integrated Weed Management in Cereals. p. 127-134. 


\title{
SELOSTUS
}

\section{Herbisidien käytön vähentäminen kevätviljan viljelyssä}

\author{
JUKKA SALONEN
}

Maatalouden tutkimuskeskus

\begin{abstract}
Rikkakasvien kemiallinen torjunta yleistyi Suomessa 1960luvun puolivälissä. Herbisidien käyttö on muun viljelyteknisen kehityksen ohella lisännyt viljelykasvien satoa ja viljelyn kannattavuutta. Herbisidien käytön tarkentamista on kuitenkin perusteltu mm. tuotantokustannusten optimoinnilla ja torjunta-aineiden haitallisilla ympäristövaikutuksilla. Tässä tutkimuksessa selvitettiin herbisidien merkitystä ja käyttöä kevätviljan viljelyssä, joka on suurin herbisidien käyttökohde.

Tutkimus jakautui i) peltojen rikkakasvilajiston, rikkakasvien runsauden ja herbisidien tehokkuuden selvittämiseen Etelä- ja Keski-Suomen viljelyksillä, sekä ii) kenttäkokeisiin, joissa tutkittiin suositeltua pienempien herbisidiannosten käyttökelpoisuutta. Tavoitteena oli tarkentaa kevätviljan viljelyssä yleisimmin käytettyjen fenoksihappoherbisidien käyttösuosituksia nykyistä tarvetta vastaaviksi.
\end{abstract}

\section{Kevätviljapeltojen rikkakasvilajisto}

Etelä- ja Keski-Suomen kevätviljapelloilla kasvoi 1980-luvun alussa keskimäärin 170 rikkakasvia/m² (mediaani 124) ja niiden tuottama ilmakuiva biomassa oli keskimäärin $320 \mathrm{~kg} / \mathrm{ha}$ (mediaani 183) ruiskuttamattomilla näytealoilla. Rikkakasvien lukumäärä ja paino pinta-alayksikköä kohden olivat vähentyneet kolmannekseen 1960-luvun alun tilanteeseen verrattuna.

Peltojen rikkakasvillisuus koostui pääosin kaksisirkkaisista lajeista. Yleisimpiä ja runsaimmin esiintyneitä rikkakasveja olivat jauhosavikka, pillikkeet, pelto-orvokki, pihatähtimö ja kiertotatar. Yleisin rikkaheinä oli juolavehnä.

Yksittäisen pellon rikkakasvillisuus koostui keskimäärin seitsemästä (2-13) torjunnan kannalta merkittävästä lajista. Kenttäkokeissa todettiin, että herbisidien suositeltuna ruiskutushetkenä viljan 3-4 -lehtiasteella rikkakasveista oli taimettunut keskimäärin 70-75 \%. Hyvässä kasvukunnossa oleva vilja kuitenkin ehkäisi herbisidiruiskutuksen jälkeen taimettuneiden rikkakasvien kasvun varsin tehokkaasti.

Kevätviljapeltojen rikkakasvillisuuteen vaikuttavia tekijöitä havainnollistettiin ordinaatioanalyysillä. Rikkakasvien esiintymiseen vaikuttivat maaperätekijät sekä viljelytekniset toimet kuten viljelykierto ja torjunta-aineiden käytön yleisyys. Yksittäisiä rikkakasvien esiintymiseen vaikuttavia tekijöitä ei havaintoaineistosta voitu erottaa, sillä maaperään ja viljelytoimiin liittyvät tekijät kytkeytyivät toisiinsa. Peipit, matarat, peltoemäkki ja saunakukka olivat yleisiä Etelä- ja Lounais-Suomen viljanviljelyalueella, jossa maalaji oli pääasiassa savea. Keski-Suomessa, jossa viljelykierto on monipuolisempaa ja maalajit kevyempiä, tyypillisiä lajeja olivat hierakat, tatarlajit ja leinikit. Jauhosavikkaa ja pillikettä esiintyi kaikkialla.

\section{Herbisidien tehokkuus}

MCPA-valmisteet ja yleisimmät seosvalmisteet (MCPA/ diklorproppi, MCPA/mekoproppi) muodostivat yhdessä $91 \%$ viljelyksillä käytetyistä herbisideistä. Ruiskutus MCPA:lla vähensi rikkakasvien biomassaa keskimäärin $65 \%$ ja seosvalmisteilla $83 \%$ käsittelemättömään havaintoruutuun verrattuna. Kenttäkokeissa oli suositellulla annoksella ruiskutettujen herbisidiseosten teho vastaavasti $85-90 \%$.

Alimman nykyisin suositellun herbisidiannoksen pienentäminen $30 \%$ :lla heikensi MCPA/diklorproppi-, MCPA/fluroksipyyri- ja MCPA/mekoproppi-valmisteiden tehoa keskimäärin alle 10 prosenttiyksikköä. Vieläkin pienemmät herbisidimäärät olivat riittäviä, jos torjunta tehtiin hyvissä oloissa ja herbisidi valittiin rikkakasvilajiston mukaan. Riski torjunnan epäonnistumisesta kasvoi kuitenkin annosta pienennettäessä.

Tulosten perusteella voidaan suositella nykyisin voimassa olevien annossuositusten pienentämistä 30 prosentilla. Nykyistä pienempien annosten käyttö edellyttää viljelijöiltä taitoa valita herbisidi rikkakasvilajiston mukaan. Tietokonepohjaiset asiantuntijajärjestelmät ovat tulossa viljelijöiden avuksi herbisidiä ja tarpeenmukaista annosta valittaessa. Tästä tutkimuksesta saadut tulokset antavat arvokasta tietoa asiantuntijajärjestelmien kehittämiseen.

\section{Herbisidien käyttötarve}

Rikkakasvien osuus viljakasvuston kokonaisbiomassasta oli alle $5 \%$ ruiskuttamattomillakin näytealoilla. Nykyistä viljelytekniikkaa käyttäen ja kylvötiheyssuosituksia noudattaen viljakasvustot kehittyvät erittäin kilpailukykyisiksi yleisimpiä rikkakasvejamme vastaan. Rikkakasvit vähensivätkin viljan satoa keskimäärin alle $5 \%$. Herbisidiruiskutus suositeltua pienemmillä annoksilla tuotti saman satotuloksen kuin suositellulla ainemäärällä ruiskutettuna.

Viljan kylvösiemenmäärän lisääminen ei osoittautunut taloudelliseksi vaihtoehdoksi rikkakasvien torjunnassa. Hyvinkin pienillä herbisidiannoksilla ehkäistiin rikkakasvien kasvua tehokkaammin kuin viljan suositeltua kasvutiheyttä lisäämällä. Viljan kasvutiheys ei vaikuttanut ruiskutushetkeen mennessä taimettuneiden rikkakasvien lukumäärään, mutta tiheä viljakasvusto ehkäisi rikkakasvien biomassan kasvua myöhemmin kesällä. 
Luotettavia kynnysarvoja herbisidin käytöstä luopumiselle ei löydetty. Herbisidien käyttötarvetta ei voitu arvioida pelkästään taimettuneiden rikkakasvien lukumäärän perusteella, sillä lukumäärä ei yksinään kuvannut kasvustoon myöhemmin kesän aikana kehittyvää rikkakasvimassaa eikä viljalle aiheutuvaa sadon menetystä. Muutama rikkakasvi neliömetrillä harvassa viljelykasvustossa saattoi tuottaa enemmän biomassaa ja rikkasiemeniä kuin yli sata yksilöä tasaisesti orastuneessa hyvässä kasvukunnossa olevassa kasvustossa.

Herbisidien käyttö ei kaikissa tilanteissa ollut taloudellisesti kannattavaa, jos torjunnan hyötyä arvioidaan pelkästään sadon määränä. Herbisidien käytöstä luopuminen lisää kui- tenkin maahan kertyvien rikkasiementen määrää. Herbisidien jatkuva käyttö pienillä annosmäärilläkin osoittautui tässä suhteessa turvallisemmaksi vaihtoehdoksi kuin välivuodet torjunnassa.

Rikkakasvien määrän ja lajiston suuri vuosittainen ja peltokohtainen vaihtelu edellyttää rikkakasvillisuuden kartoitusta joka vuosi ennen herbisidivalintaa ja -ruiskutusta. Ruiskutuksen ajoitus rikkakasvien varhaiselle taimivaiheelle tuo mahdollisuuden käyttää nykyistä pienempiä herbisidiannoksia. Näin menetellen, realistisena tavoitteena voidaan pitää viljaherbisidien käytön vähenemistä Suomessa 30 prosentilla. 


\section{ERRATA FOR THE ORIGINAL ARTICLES}

\section{Chapter III.}

Position p. 485. Table 2.

\begin{tabular}{lrr} 
& Ylistaro & \\
\hline 10986 & 1987 & 1989 \\
\hline
\end{tabular}

\section{Correction}

\begin{tabular}{lrr}
\multicolumn{3}{c}{ Ylistaro } \\
\hline 1986 & 1987 & 1988 \\
\hline
\end{tabular}

\section{Chapter IV.}

Position p. 495. Fig. 1.

Fig. 1. Dose-response of crop yield (open symbols) and weed biomass (closed symbols) to the MCPA/mecoprop treatment in three growth densities of (a) spring barley and (b) spring wheat in Jokioinen in 1988. ( $\bigcirc)$ indicates the normal, $(\square) 200$ seeds lower and $(\diamond) 200$ seeds higher sowing densities.

\section{Correction (of symbols)}

Fig. 1. Dose-response of crop yield (open symbols) and weed biomass (closed symbols) to the MCPA/mecoprop treatment in three growth densities of (a) spring barley and (b) spring wheat in Jokioinen in 1988. ( $\square$ ) indicates the normal, $(\bigcirc) 200$ seeds lower and $(\diamond) 200$ seeds higher sowing densities. 



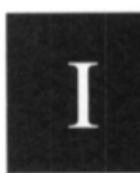





\title{
Weed infestation and factors affecting weed incidence in spring cereals in Finland - a multivariate approach
}

\begin{abstract}
JUKKA SALONEN
SALONEN, J. 1993. Weed infestation and factors affecting weed incidence in spring cereals in Finland - a multivariate approach. Agric. Sci. Finl. 2: 000-000. (Agric. Res. Centre of Finland, Inst. Pl. Prot., FIN-31600 Jokioinen, Finland.)

Weed vegetation of spring cereal fields in southern and central Finland was analyzed by ordination methods to provide a community level description of weed populations. Attention was paid particularly to the relative importance of environmental factors affecting weed incidence such as crop management, soil properties and weather conditions. A data set of 33 weed taxa from 252 fields was subjected to both indirect and direct gradient analysis. Indirect ordination was obtained with correspondence analysis (CA), and direct gradient analyses were performed with redundancy analysis (RDA) and with canonical correspondence analysis (CCA) relating environmental factors to the occurrence of weeds. Among several management factors, continuous herbicide use explained best the variation in the species composition of weed flora. Weed vegetation was also associated with soil type, moisture conditions and soil $\mathrm{pH}_{\mathrm{H}_{2} \mathrm{O}}$. Ordination diagrams visualized the species-environment interactions and detected characteristic weed species for different geographical regions. In addition to ordination analyses of weed flora, the level and structure of weed infestation are described. The density of weeds averaged 170 plants $\mathrm{m}^{-2}$ (median=124) and the air-dry weight of weeds $320 \mathrm{~kg}$ $\mathrm{ha}^{-1}($ median=183). The average weed density was the same in different soil types, but the weed biomass was lower in clay soils than in coarse mineral and organic soils.
\end{abstract}

Key words: broad-leaved weeds, ordination, barley, oats, wheat, canonical correspondence analysis, CA, CCA, RDA, CANOCO

\section{Introduction}

Arable fields are continuously subjected to different agricultural measures particularly in annual crops. Although many weed species are adapted to the prevailing conditions, the constantly changing habitat selectively affects weed communities and, consequently, changes the weed flora (RADEMACHER et al. 1970, REUSS 1981, MAHN 1984, CHANCELlor 1985, LÉGÈrE et al. 1993).

Weed flora in spring cereals was investigated during 1982-84 in Finland (ERVIÖ and SALONEN
1987). Attention was paid particularly to the changes in weed infestation by comparing the data with the previous study from the 1960s (MUKULA et al. 1969). The occurrence of individual weed species was related to several explanatory variables by the analysis of variance and regression techniques. These methods are appropriate if detailed responses of particular weed species to explanatory factors are studied. The problem was, however, to give a summary of the relative importance of factors affecting the weed incidence. Therefore, the data from weed survey was subjected to ordination 
analyses which have proved to be appropriate for community level description of weed vegetation (TER BRAAK 1987a).

Multivariate analysis of community data is frequently applied in ecological studies to summarize the information in samples-by-species data matrices (GAUCH 1982). In weed science, the multivariate approach is feasible to describe and predict the response of weed vegetation to farming practices (PosT 1988). Multivariate methods in ecology can be divided into three groups (JONGMAN et al. 1987): direct gradient analysis (regression), indirect gradient analysis (ordination) and classification (cluster analysis). Indirect methods analyze the species data only, whereas species-environment interactions can be analyzed simultaneously by direct methods.

In this paper, the weed survey data from 19821984 was subjected to ordination analyses to give a community level description of weed flora in spring cereal fields. The objective was to find characteristic weed species in different geographical regions and to illustrate responses of weed vegetation to environmental factors. Furthermore, the level of weed infestation, proportion of the most abundant weed species and the occurrence of weeds in different soil types are reported.

\section{Material and methods}

A total of 267 spring cereal fields (barley, oats or wheat) in southern and central Finland were studied during 1982-1984. In each field there were 4 to 5 sample plots of $0.25 \mathrm{~m}^{-2}$ in size from which the above-ground occurrence of 33 weed species (Table 1) or, in fact, weed taxa was assessed in late July by counting the number and weighing the airdry biomass of weeds. The sample plots were not sprayed with herbicides. Frequency of weeds (Table 1) denotes the proportion of the fields where the particular weed species was observed out of the all fields studied. Detailed information of the survey and the occurrence of weed species has been given by ERVIÖ and SALONEN (1987).

Data on factors involved in each field was collected either by observing, measuring or by interviewing the farmer. Twelve factors describing either the current crop, crop rotation, soil properties or climate (Table 2) were used as environmental variables in the CCA. The factors were chosen from among the 21 factors studied in the regression analysis and considered the most important (ERVIÖ and SALONEN 1987). The survey localities were grouped into three regions based on their geographical locations: South-western Finland (SW), eastern part of central Finland (CE) and western part of central Finland (CW).

Features of regression analysis and ordination are integrated in canonical ordination techniques (Jongman et al. 1987). These techniques provide a direct analysis of species-environment interactions which was earlier possible only by regression methods. 'Canonical correspondence analysis' (CCA) by TER BRAAK (1986) is probably the most common canonical ordination technique currently applied in various ecological studies (BIRKS and Austin 1992). CCA and the related indirect technique 'correspondence analysis' (CA) (GAUCH 1982) have been applied also in agricultural research (Jukola-Sulonen 1983, Wentworth et al. 1984, Post 1986, SIEPEL et al. 1989, PYŠEK and LePS 1991, DAle et al. 1992). CA and CCA fit the unimodal curve to the species-environment data, whereas a linear response model between species data and environmental variables can be fitted by the 'redundancy analysis' (RDA). The ordination techniques mentioned above are all available in the computer program CANOCO (TER BRAAK 1987b).

Environmental variables were either qualitative (nominal scale) or quantitative (interval scale) (Table 2). The crop rotation was considered cereal dominant if a cereal crop had been grown at least for three years of the previous four years. Otherwise it was classified as mixed rotation. The use of herbicides indicates only the intensity of chemical weed control, not the type of herbicides applied during the last nine years. The soil $\mathrm{pH}_{\mathrm{H}_{2} \mathrm{O}}$ was measured from the top $0-20 \mathrm{~cm}$ layer. The soil type of fields was classified into three categories: clay (clay content $>30 \%$ ), organic ( $>20 \%$ organic matter) and coarse mineral soils. The subjective assessment of soil moisture was primarily based on the soil type and the drainage of the field. Nominal type environmental factors were transformed into binary dummy variables. Due to missing values of explanatory factors, some sample fields had to be excluded, since missing data are not accepted in the CANOCO run. Thus, a final data set consisted of 
Table 1. Frequency, the effective number of occurrences (N2) and average biomass production of the 33 weed species studied in 252 spring cereal fields. Frequency denotes the proportion of the fields where the species was found. The N2 value obtained from the CANOCO run is based on the weighted averages of weed densities and it indicates the number of fields where the species was abundant. Air-dry biomass indicates the average infestation of the species in those fields it was found.

\begin{tabular}{|c|c|c|c|c|}
\hline Weed taxa & Code" 1 & $\begin{array}{c}\text { Frequency } \\
\%\end{array}$ & $\mathrm{~N} 2$ & $\begin{array}{c}\text { Biomass } \\
\mathrm{g} \mathrm{m}^{-2}\end{array}$ \\
\hline Chenopodium album $\mathrm{L}$. & CHEAL & 87 & 163 & 5.0 \\
\hline Galeopsis spp. L. & GAESS & 85 & 166 & 6.1 \\
\hline Viola arvensis MURRAY & VIOAR & 85 & 146 & 1.0 \\
\hline Stellaria media (L.) VILL. & STEME & 81 & 155 & 2.8 \\
\hline Fallopia convolvulus (L.) Á. LÖVE & POLCO & 61 & 112 & 1.3 \\
\hline Erysimum cheiranthoides $\mathrm{L}$. & ERYCH & 58 & 95 & 1.5 \\
\hline Lapsana communis $\mathrm{L}$. & LAPCO & 54 & 94 & 4.0 \\
\hline Polygonum aviculare L. & POLAV & 52 & 71 & 0.5 \\
\hline Myosotis arvensis (L.) HILL & MYOAR & 52 & 66 & 0.5 \\
\hline Elymus repens (L.) GOULD & AGRRE & 51 & 92 & 13.0 \\
\hline Spergula arvensis $\mathrm{L}$. & SPRAR & 46 & 68 & 2.9 \\
\hline Fumaria officinalis $\mathrm{L}$. & FUMOF & 43 & 74 & 1.4 \\
\hline Galium spp. L. & GALSS & 35 & 57 & 1.0 \\
\hline Tripleurospermum inodorum SCHULTZ BIP. & MATIN & 32 & 34 & 0.7 \\
\hline Polygonum lapathifolium L. & POLLA & 30 & 45 & 1.7 \\
\hline Sonchus arvensis $\mathrm{L}$. & SONAR & 27 & 43 & 2.8 \\
\hline Lamium spp. L. & LAMSS & 25 & 39 & 1.9 \\
\hline Matricaria matricarioides (LESS.) PORTER & MATMT & 18 & 23 & 1.9 \\
\hline Gnaphalium uliginosum L. & GNAUL & 18 & 15 & 0.1 \\
\hline Capsella bursa-pastoris (L.) MEDIK. & CAPBP & 17 & 23 & 0.3 \\
\hline Ranunculus repens $\mathrm{L}$. & RANRE & 17 & 13 & 0.2 \\
\hline Thlaspi arvense $\mathrm{L}$. & THLAR & 16 & 21 & 0.8 \\
\hline Equisetum spp. L. & EQUSS & 13 & 26 & 2.1 \\
\hline Brassica rapa L. ssp. oleifera DC. (volunt.) & BRSRO & 13 & 25 & 4.0 \\
\hline Poа аппиа $\mathrm{L}$. & POAAN & 13 & 14 & 0.5 \\
\hline Brassica spp. L. & BRSSS & 12 & 15 & 4.2 \\
\hline Rumex spp. L. (Sorrels) & RUMSS & 12 & 14 & 0.7 \\
\hline Achillea spp. L. & ACHSS & 5 & 11 & 2.1 \\
\hline Cirsium arvense (L.) SCOP. & CIRAR & 5 & 7 & 2.0 \\
\hline Sonchus spp. L. (S. asper, S. oleraceus) & SONSS & 4 & 5 & 9.4 \\
\hline Urtica spp. L. & URTSS & 2 & 1 & 0.5 \\
\hline Avena fatua $\mathrm{L}$. & AVEFA & 1 & 2 & 9.4 \\
\hline Stachys palustris L. & STAPA & 1 & 1 & 3.0 \\
\hline
\end{tabular}

1) Weed codes are according to the BAYER standard (BAYER 1992).

252 fields. The geographical regions were used as environmental variables in RDA, and as covariables in partial CCA.

Ordination analyses were performed with the CANOCO program (TER BRAAK 1987b) applying CA, CCA and RDA. Ordination diagrams (speciesenvironment biplots) were drawn with the CANODRAW program (ŠMILAUER 1990). The relationship between the weed communities and environmental variables is displayed with the first two ordination axes. Only the central area of the diagram is shown to improve the visibility of species near the origin. Consequently, some species and environmental variables lie outside the drawn area (Figs. 4 and 5).

Due to the skewed distribution of the response values (weed density and weed biomass) the weed data was log-transformed $(\ln (y+1))$ in the CANOCO run. Species diversity was described by the N2 value from the CANOCO output. The N2 
Table 2. Environmental variables subjected to the canonical correspondence analysis (CCA).

\begin{tabular}{|c|c|c|}
\hline Variable (scale) & Code & $\begin{array}{c}\text { Range or } \\
\text { No. of fields }\end{array}$ \\
\hline \multicolumn{3}{|l|}{ CROP VARIABLES } \\
\hline Cover, $\%$ (interval) & COVER & $13-100$ \\
\hline Yield, kg ha-1 (interval) & YIELD & $520-7300$ \\
\hline \multicolumn{3}{|l|}{ MANAGEMENT VARIABLES } \\
\hline \multicolumn{3}{|l|}{ Cereal dominance (nominal) } \\
\hline Cereals & CER & 144 \\
\hline Mixed rotation & MIX & 108 \\
\hline \multicolumn{3}{|l|}{ Herbicide use during } \\
\hline 9 previous years (interval) & HERB & \\
\hline 0 years & & 6 \\
\hline 1 & & 8 \\
\hline 2 & & 14 \\
\hline 3 & & 26 \\
\hline 4 & & 20 \\
\hline 5 & & 30 \\
\hline 6 & & 17 \\
\hline 7 & & 14 \\
\hline 8 & & 20 \\
\hline 9 & & 97 \\
\hline \multicolumn{3}{|l|}{ SOIL VARIABLES } \\
\hline \multicolumn{3}{|l|}{ Soil type (nominal) } \\
\hline Coarse & COARSE & 110 \\
\hline Clay & CLAY & 112 \\
\hline Organic & ORGANIC & 30 \\
\hline \multicolumn{3}{|l|}{ Moisture type (nominal) } \\
\hline Dry & DRY & 40 \\
\hline Normal & NORMAL & 199 \\
\hline Wet & WET & 13 \\
\hline Soil $\mathrm{pH}_{\mathrm{H}_{2} \mathrm{O}}$ (interval) & $\mathrm{PH}$ & $4.85-7.65$ \\
\hline \multicolumn{3}{|c|}{ CLIMATIC VARIABLES (between sowing and sampling) } \\
\hline $\begin{array}{l}\text { Effective temperature } \\
\text { sum, DD (base } 5^{\circ} \mathrm{C} \text { ) (interval) }\end{array}$ & ETS & $281-857$ \\
\hline Precipitation, mm (interval) & PREC & $40-222$ \\
\hline
\end{tabular}

value is analogous to Hill's N2 diversity number (HILL 1973). For samples, N2 is the inverse of Simpson's diversity index (LUDWIG and REYNOLDS 1988):

$$
\mathrm{N} 2=1 / \lambda
$$

where

$$
\lambda=\sum_{i=1}^{\mathrm{s}}\left(\mathrm{n}_{\mathrm{i}} / \mathrm{N}\right)^{2}, \mathrm{i}=1,2,3 \ldots \ldots . \mathrm{S}
$$

where $\lambda$ is Simpson's diversity index, $\mathrm{n}_{\mathrm{i}}$ is the number of ith species in the population and $\mathrm{N}$ is the total number of all $\mathrm{S}$ species in the population.

\section{Results}

\section{Occurrence of weeds}

The weed density averaged 170 plants $\mathrm{m}^{-2}(\mathrm{SE}=10$, median=124) and the biomass production $320 \mathrm{~kg}$ $\mathrm{ha}^{-1}(\mathrm{SE}=23$, median $=183)$. The total weed biomass correlated weakly $(r=0.54, \mathrm{P}<0.01)$ with the total weed density. A typical weed density was 50-150 weeds $\mathrm{m}^{-2}$, whereas the biomass production was distributed more evenly into different classes (Fig. 1). Weed densities in different soil types were at the same level, but the biomass production of weeds was on average lower in clay soils than in coarse mineral or organic soils (Fig. 2).

Only ten weed species occurred in more than half of the fields studied (Table 1). The ranking order based on the $\mathrm{N} 2$ value was slightly different from the frequency order. The N2 value for samples averaged 6.9 (range 2.1-13.4), i.e. on average there were seven relatively abundant weed species in each field.

Moreover, in order to emphasize the relative importance of different weed species, they were ranked according to their average biomass production (Table 1), and also with regard to their proportion of the total density and biomass of weeds (Fig. 3 ). The nine most dominant weeds constituted twothirds of the total weed infestation.

\section{Species-environment relationships}

CCA and RDA were applied to the species ordination in the three geographical regions. Both techniques characterized the typical weed species of different regions illustrated here by the RDA diagram (Fig. 4) which provided a slightly better separation of samples and weed species than the CCA diagram.

The CCA ordination diagrams for the density and biomass data were very much alike. Thus, only 

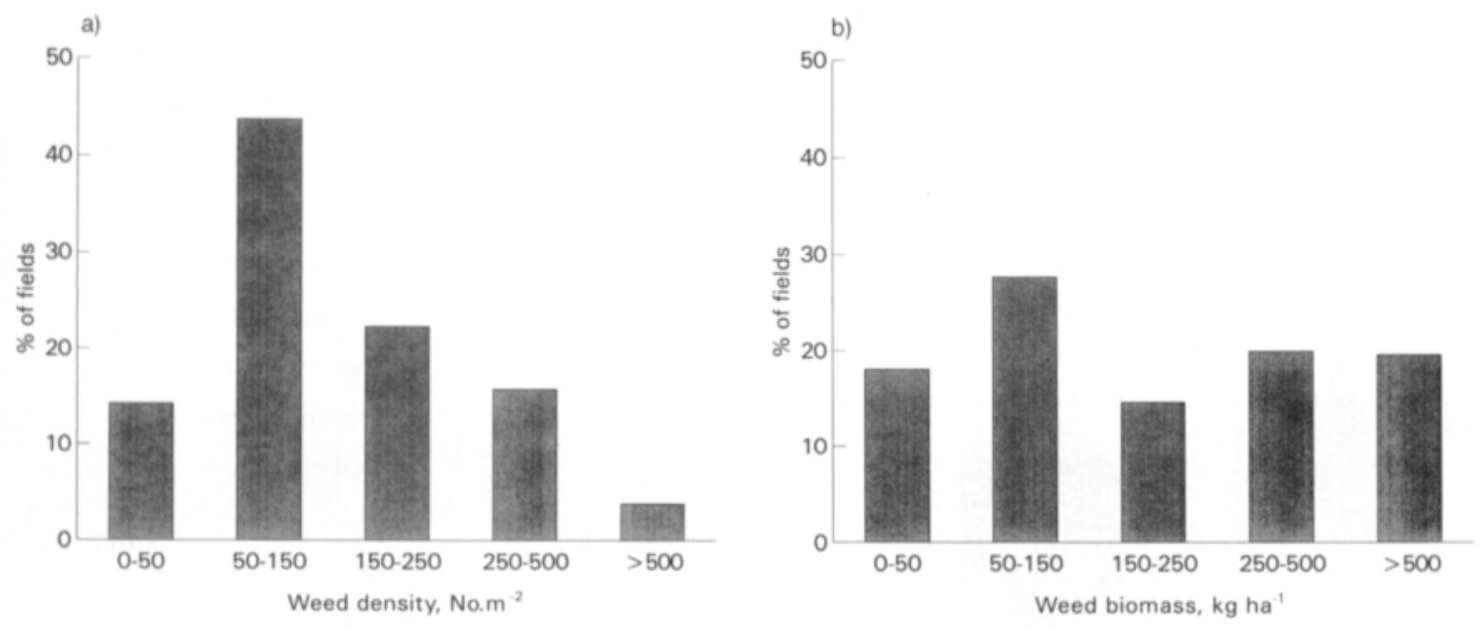

Fig. 1. Distribution of spring cereal fields into weed infestation classes according to a) weed density and b) air-dry biomass. Assessment was made from unsprayed sample plots in July.

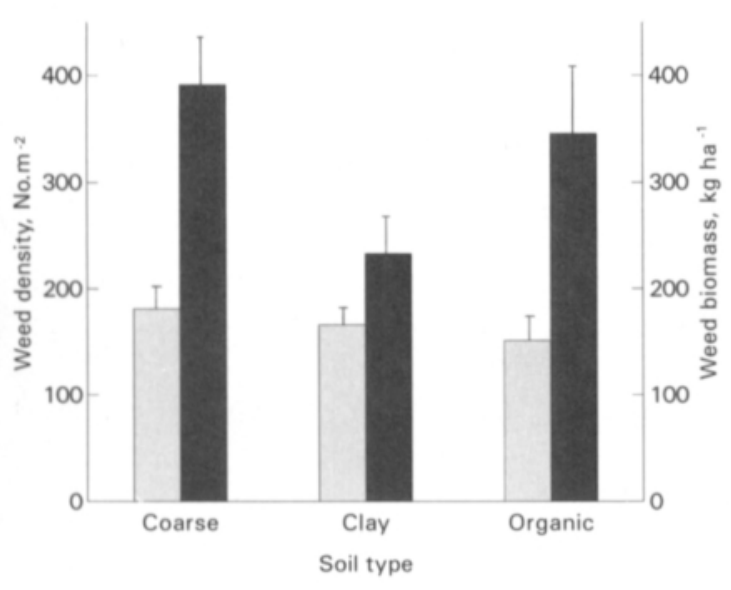

Fig. 2. Weed infestation in different soil types. The mean weed density (left bar) and air-dry biomass (right bar) in unsprayed fields. Vertical line indicates the standard error of the mean.

the diagram for biomass data is shown, since it provided somewhat higher eigenvalues (Table 3, Fig. 5). Eigenvalue denotes the dispersion of the species scores along the ordination axis, and is thus a measure of importance of the ordination axis (JoNGMAN et al. 1987).
The first canonical axis ("x-axis") extracted by CCA was closely related to the management practices, as indicated by long vectors and nearby centroids of nominal factors (Fig. 5) and by high interset correlations with the axis (Table 4). Continuous herbicide application proved to be the most "effective" factor explaining the composition of weed flora.

The second axis ("y-axis") was associated with soil variables, particularly $\mathrm{pH}$, and with climatic factors, precipitation and effective temperature sum between sowing and sampling. Galeopsis spp. and Polygonum spp. occurred frequently in moist organic soils, whereas Sonchus spp., Poa annua and Lapsana communis thrived in coarse soils and warm and humid weather conditions which were typical of the eastern region of the survey.

Although the eigenvalues obtained by CCA were low, the first two canonical axes from the constrained ordination accounted for $49 \%$ of the total species-environment variation. In the analysis of weed density, the corresponding value was $53 \%$. Partial CCA with regions as covariables slightly reduced the explained variance. The first canonical axis was statistically significant $(\mathrm{P}=0.01$, Monte Carlo permutation test) in all analyses. 


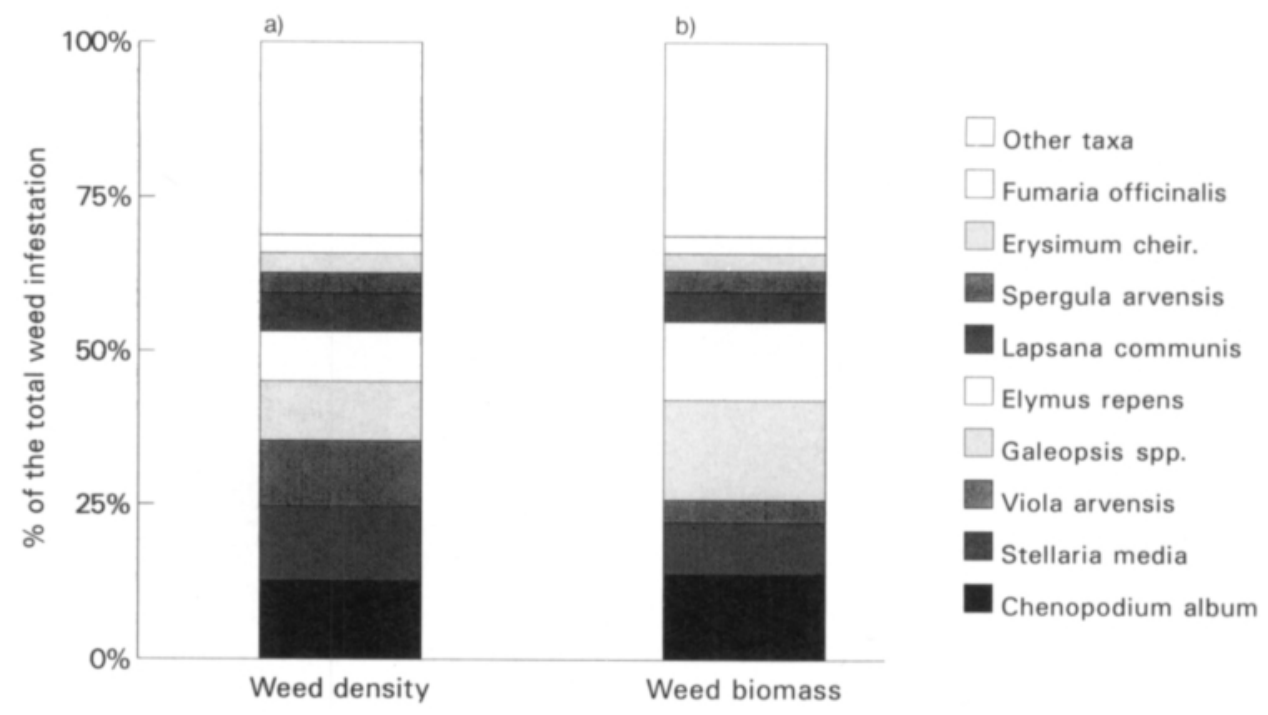

Fig. 3. Mean proportion (\%) of the most abundant weed species of (a) the total weed density and (b) weed biomass in unsprayed spring cereal fields. Assessment was made in July.

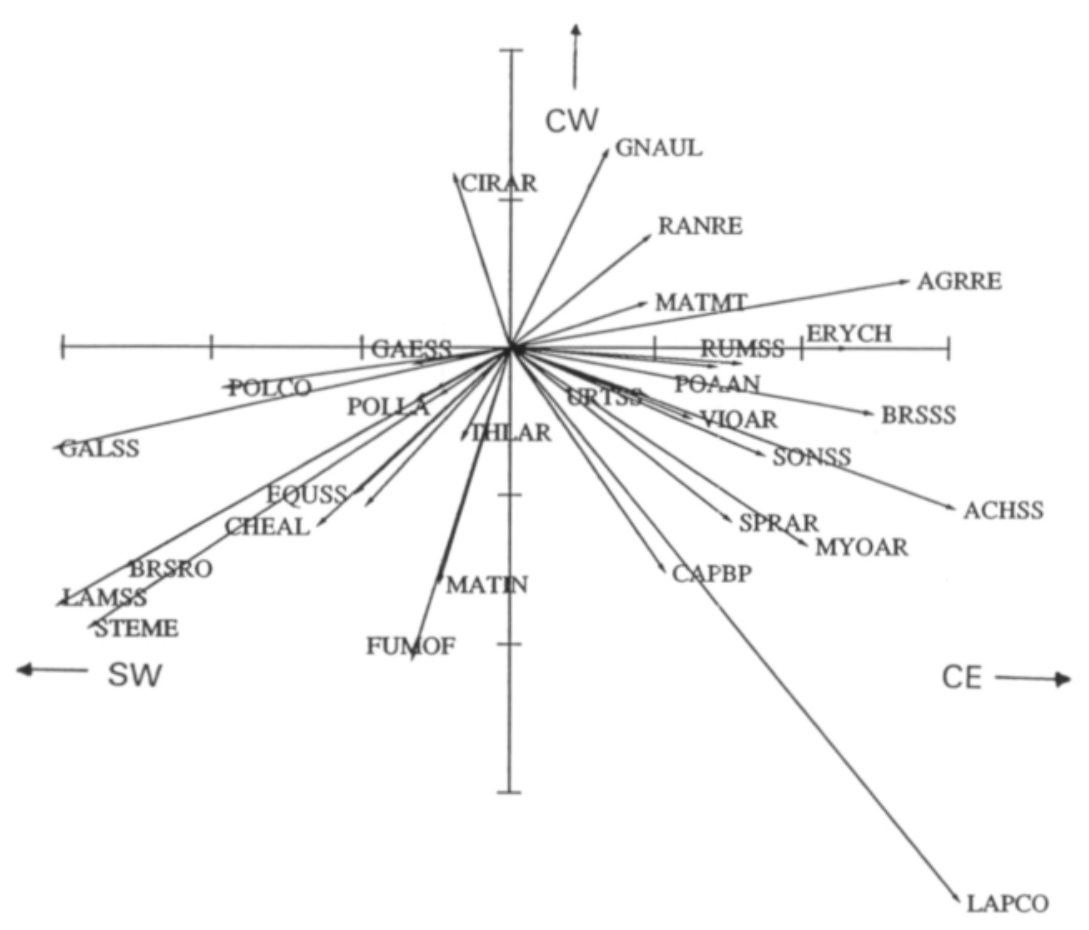

Fig. 4. Ordination diagram based on redundancy analysis (RDA) of weed densities describing indicator species for southwest (SW), central-east (CE) and central-west (CW) regions of Finland. Centroids of all regions lie outside the range of the diagram. Some species near the origin are not shown because of their overlapping position. 


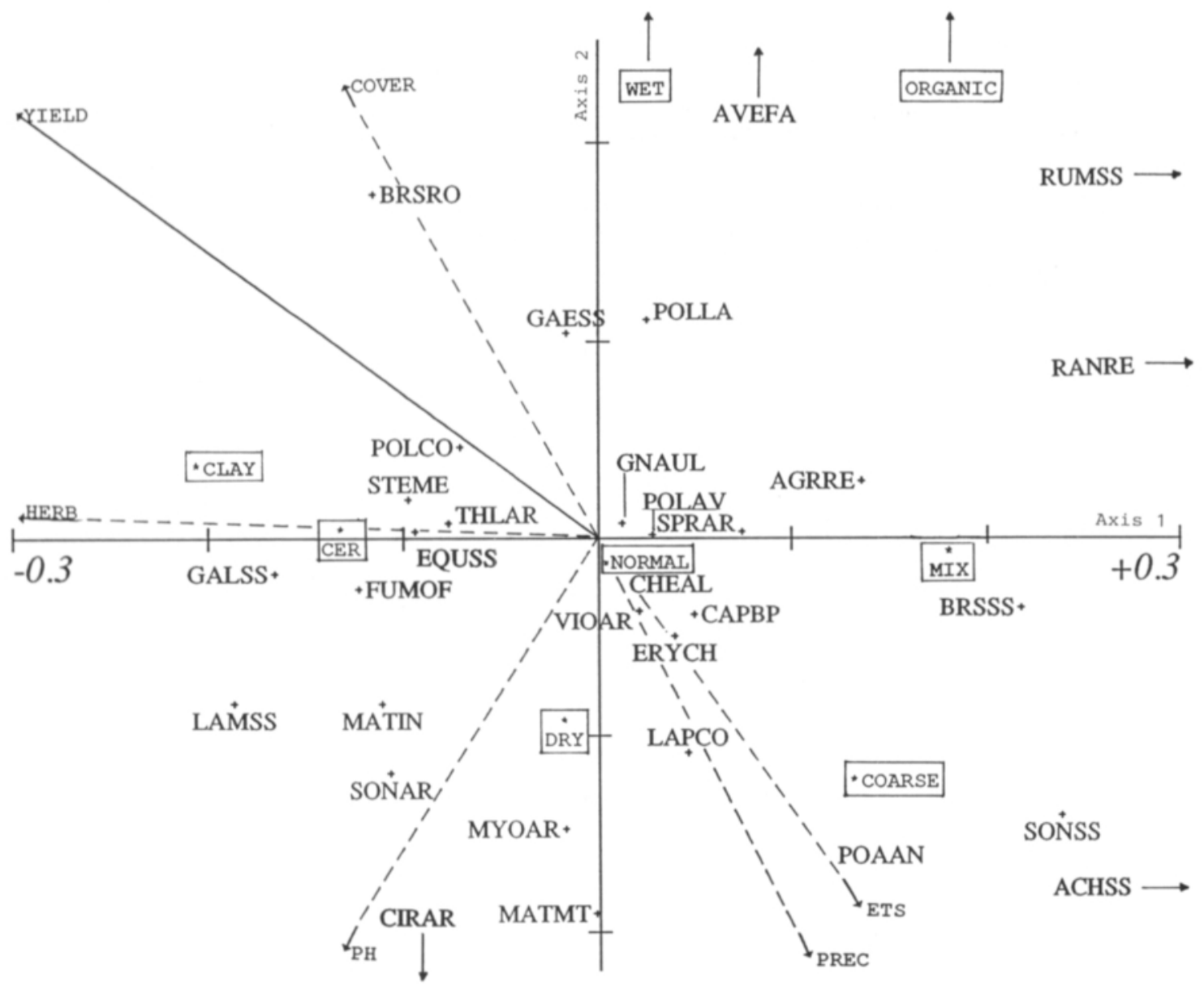

Fig. 5. Ordination diagram based on canonical correpondence analysis (CCA) of weed biomass data from 252 spring cereal fields. The end of dotted vectors lies outside the range of the diagram. Two species (STAPA, URTSS) near the origin are not shown because of their overlapping position with other species.

Key to abbreviations

Weed species: ACHSS = Achillea spp., AGRRE $=$ Elymus repens, AVEFA $=$ Avena fatua, BRSSS $=$ Brassica spp. , $\mathrm{BRSRO}=$ Brassica rapa ssp. oleifera, $\mathrm{CAPBP}=$ Capsella bursapastoris, $\mathrm{CHEAL}=$ Chenopodium album, $\mathrm{CIRAR}=$ Cirsium arvense, $\mathrm{EQUSS}=$ Equisetum $\mathrm{spp} ., \mathrm{ERYCH}=$ Erysimum cheiranthoides, $\mathrm{FUMOF}=$ Fumaria officinalis, $\mathrm{GAESS}=$ Galeopsis spp, GALSS = Galium spp., GNAUL = Gnaphalium uliginosum, LAMSS = Lamium spp., LAPCO = Lapsana communis, MATIN $=$ Tripleurospermum inodorum, MATMT $=$ Matricaria matricarioides, $\mathrm{MYOAR}=$ Myosotis arvensis, $\mathrm{POAAN}=$ Poa annua, $\mathrm{POLAV}=$ Polygonum aviculare, $\mathrm{POLCO}=$ Fallopia convolvulus, $\mathrm{POLLA}=$ Polygonum lapathifolium, $\mathrm{RANRE}=$ Ranunculus repens, RUMSS = Rumex spp., SONAR = Sonchus arvensis, SONSS = Sonchus spp., SPRAR = Spergula arvensis, STAPA $=$ Stachys palustris, $\mathrm{STEME}=$ Stellaria media, $\mathrm{THLAR}=$ Thlaspi arvense, $\mathrm{URTSS}=$ Urtica spp., VIOAR $=$ Viola arvensis. Weed codes are according to the BAYER standard (BAYER 1992).

Explanatory factors: $\mathrm{CER}=$ Cereal-dominated rotation, $\mathrm{CLAY}=$ Clay soil, $\mathrm{COARSE}=\mathrm{Coarse}$ soil, $\mathrm{COVER}=\mathrm{Crop}$ cover, DRY $=$ Dry soil, ETS $=$ Effectice temperature sum between sowing and sampling, HERB = Duration of herbicide use, $\mathrm{MIX}=$ Mixed crop rotation, $\mathrm{NORMAL}=$ Normal soil moisture, ORGANIC $=$ Organic soil, $\mathrm{PH}=\mathrm{Soil} \mathrm{pH} \mathrm{H}_{2} \mathrm{O}, \mathrm{PREC}=$ Precipitation sum between sowing and sampling, WET $=$ Wet soil, YIELD $=$ Crop yield. 
Table 3. Eigenvalues $\left(\lambda_{1-4}\right)$ corresponding to the first four ordination axes from Correspondence Analysis (CA) and Canonical Correspondence Analysis (CCA). Environmental values for CCA are given in Table 2. Partial analyses were performed with regions as covariables. Weed infestation values from 252 spring cereal fields were transformed with $\ln (y+1)$.

\begin{tabular}{lcccc}
\hline & \multicolumn{4}{c}{ Eigenvalues } \\
\cline { 2 - 5 } Ordination method & $\lambda_{1}$ & $\lambda_{2}$ & $\lambda_{3}$ & $\lambda_{4}$ \\
\hline \multirow{5}{c}{ Weed density data } \\
CA & 0.253 & 0.209 & 0.194 & 0.181 \\
CCA & 0.122 & 0.073 & 0.048 & 0.030 \\
Partial CCA & 0.076 & 0.056 & 0.037 & 0.030 \\
& \multicolumn{5}{c}{ Weed biomass data } \\
CA & 0.315 & 0.281 & 0.275 & 0.263 \\
CCA & 0.142 & 0.097 & 0.065 & 0.046 \\
Partial CCA & 0.101 & 0.066 & 0.063 & 0.046 \\
\hline
\end{tabular}

\section{Discussion}

The average weed density in spring cereal fields was relatively low, as in $58 \%$ of the fields the weed density remained below 150 plants $\mathrm{m}^{-2}$, and the median weed density was only 124 plants $\mathrm{m}^{-2}$. Since the density values showed a skewed distribution, the median value is a more appropriate measure to indicate the level of weed infestation in spring cereal fields. The results correspond to the present weed infestation levels found in field experiments in the Nordic countries (HALlgREN 1993, SALONEN 1993).

The weed flora was dominated by rather few species (Table 1, Fig. 3) which is a common phenomenon in intensified farming systems (NEU. RURer 1965, Callauch 1981, Albrecht and BACHTHALER 1988). The low number of abundant species makes e.g. the choice of herbicides easier.

Table 4. Inter-set correlations of environmental variables with the first four ordination axes from CCA for the weed biomass data. The two highest values of each axis are underlined.

\begin{tabular}{|c|c|c|c|c|}
\hline \multirow{2}{*}{$\begin{array}{l}\text { Factor group } \\
\text { VARIABLE }\end{array}$} & \multicolumn{4}{|c|}{ Axes } \\
\hline & $\begin{array}{c}1 \\
\lambda_{1}=0.142\end{array}$ & $\begin{array}{c}2 \\
\lambda_{2}=0.097\end{array}$ & $\begin{array}{c}3 \\
\lambda_{3}=0.065\end{array}$ & $\begin{aligned} & 4 \\
& \lambda_{4}= 0.046 \\
&\end{aligned}$ \\
\hline \multicolumn{5}{|l|}{ Crop \& Management } \\
\hline $\begin{array}{l}\text { COVER (of crop) } \\
\text { YIELD } \\
\text { CER(eal dominance) } \\
\text { MIX(ed rotation) } \\
\text { HERB(icide use) }\end{array}$ & $\begin{array}{r}-0.12 \\
-0.21 \\
-0.43 \\
0.43 \\
-0.56 \\
\end{array}$ & $\begin{array}{r}0.23 \\
0.14 \\
-0.01 \\
0.01 \\
0.01\end{array}$ & $\begin{array}{r}-0.15 \\
-0.18 \\
0.09 \\
-0.09 \\
0.17\end{array}$ & $\begin{array}{r}-0.01 \\
-0.04 \\
-0.19 \\
0.19 \\
0.08\end{array}$ \\
\hline \multicolumn{5}{|l|}{ Soil } \\
\hline $\begin{array}{l}\text { Soil type } \\
\text { COARSE } \\
\text { CLAY } \\
\text { ORGANIC }\end{array}$ & $\begin{array}{r}0.35 \\
-0.47 \\
0.18\end{array}$ & $\begin{array}{r}-0.31 \\
0.08 \\
0.38 \\
\end{array}$ & $\begin{array}{r}-0.07 \\
0.04 \\
0.18\end{array}$ & $\begin{array}{r}-0.23 \\
0.15 \\
0.14\end{array}$ \\
\hline \multicolumn{5}{|l|}{ Soil moisture } \\
\hline $\begin{array}{l}\text { DRY } \\
\text { NORMAL } \\
\text { WET }\end{array}$ & $\begin{array}{l}0.02 \\
0.01 \\
0.01\end{array}$ & $\begin{array}{r}-0.11 \\
0.03 \\
0.23\end{array}$ & $\begin{array}{l}0.10 \\
0.18 \\
0.15\end{array}$ & $\begin{array}{r}0.24 \\
0.19 \\
-0.04\end{array}$ \\
\hline PH (soil) & -0.22 & $\underline{-0.45}$ & $\underline{-0.19}$ & 0.09 \\
\hline \multicolumn{5}{|l|}{ Climate } \\
\hline $\begin{array}{l}\text { ETS } \\
\text { PREC(ipitation) }\end{array}$ & $\begin{array}{l}0.18 \\
0.16\end{array}$ & $\begin{array}{l}-0.28 \\
-0.33\end{array}$ & $\begin{array}{l}0.09 \\
\underline{0.26}\end{array}$ & $\frac{-0.29}{0.06}$ \\
\hline
\end{tabular}


The mean proportion of individual weed species out of the total weed density and biomass in each field (Fig. 3) indicated that Chenopodium album, Stellaria media and Viola arvensis are the most dominant species in terms of weed density whereas, Galeopsis spp., C. album and Elymus repens were the most dominant species in terms of biomass production. Furthermore, Stellaria media and Viola arvensis had a higher proportion in densities than in biomass.

The most aggressive weed species such as Galeopsis spp. and volunteer turnip rape (BRSRO) were detected both by their proportion of total weed biomass (Fig. 3) and along the crop cover vector (COVER) in the ordination diagram (Fig. 5).

Differences in weed abundances and weed biomass production between soil types (Fig. 2) infer both to growth conditions and species composition. Apparently, differences in weed growth between soil types are also reflected in yield responses of the crop. Indeed, yield responses of cereals have been found to be the lowest in clay soils (JENSEN 1985, HALLGREN 1989).

Ordination analysis provided easily interpretable results which were in agreement with the conclusions based on the regression analysis (ERVIÖ and SALONEN 1987) with regard to the most important factors affecting the occurrence of weeds. However, the relative importance of different factors was more clearly and easily pointed out by the ordination analysis than by the regression analysis. A particular advantage in applying ordination analyses is that the CCA ordination diagrams are not in any way hampered by high correlations between weed species or between environmental variables (TER BRAAK 1987c).

The most frequent species like Chenopodium album and Viola arvensis located near the origin of the ordination diagram (Fig. 5). These species were found in all field types indicating that they are well adapted to agricultural ecosystem.

Each geographical regions had its characteristic weed species as was also concluded earlier with the analysis of variance (ERVIÖ and SALONEN 1987). Some less frequent species like Achillea spp., and Galium spp. were particularly associated with certain regions (Fig. 4).
The results achieved with RDA (Fig. 4) and CCA (Fig. 5) can be combined. Typical weed species for cereal-dominated rotations with frequent use of herbicides were Lamium spp., Galium spp., Fumaria officinalis, Tripleurospermum inodorum and volunteer turnip rape. In addition, Lamium spp. and Galium spp. thrived in clay soils as reported also by MuKUla et al. (1969) and ANDREASEN et al. (1991). Indeed, cereal-dominated crop rotations were common in south-western Finland (SW) where most of the fields were clay soils and herbicides were frequently used. In this region, turnip rape and winter cereals are common crops in rotation, thus promoting the occurrence of volunteer oilseed rape and Tripleurospermum inodorum which is a common species in winter cereals (RAATIKAINEN et al. 1978).

Long-term use of herbicides has evidently selected the weed populations in south-western Finland towards the more tolerant species like Galium spp., Lamium spp. and Tripleurospermum inodorum. Indicator species for geographical regions hopefully help e.g. advisory services to direct general control recommendations to different regions.

Some weed species were typical of central Finland. Rumex spp. (R. acetosa and R. acetosella) and Ranunculus repens are associated with grassland (RAATIKAINEN and RAATIKAINEN 1975) which is a common crop in rotations in central Finland. Polygonum spp. were characteristically in organic soils which were most often found in central Finland.

Both management practices and soil properties affected the weed vegetation. However, the effects of individual environmental variables should be interpreted with caution due to the confounded nature of several factors associated with crop rotation and crop management. Similar conclusions were drawn from the regression analysis (ERVIÖ and SALONEN 1987) and in other weed surveys (STREIBIG et al. 1984, ANDREASEN et al. 1991, DALE et al. 1992).

In general, the possibilities to draw definite conclusions from this kind of weed survey data seem to be limited due to the complex cropping history in each field as discussed also by COUSENS et al. (1988). Relatively high eigenvalues of the third and fourth axes (Table 4) indicated the complex nature 
of weed communities which was impossible to explain with the few environmental variables chosen. Obviously, more detailed information on the cropping history, like crop rotation, type of herbicides used and their control efficacy, is needed to describe better the responses of weed flora to environmental conditions. Forward selection of environmental variables in CANOCO appeared to be rather liberal in judging the variables statistically significant. This is a typical shortcoming of stepwise selection of variables because the overall size of the test is not controlled (TER BRAAK 1990).

Low eigenvalues of ordination axes reveal either short environmental gradients in cereal fields or the plasticity of most weed species to grow in diverse conditions. Low eigenvalues are also the consequence of few abundant species which occurred in most fields. As the number of observed weeds was limited to 33 taxa, the study probably ignored some weed species that might have had an explanatory power in the ordination analysis. Nevertheless, ordination diagrams illustrated some clear patterns in weed communities and related environmental factors and agricultural practices to the weed data. Ordination techniques detected groups of weed species similar to those by the TWINSPAN classification of the same data (SALONEN 1990).

In conclusion, weed flora showed a response particularly to management practices. Herbicide use affected most the composition of weed flora. This should be considered in planning the crop rotations and long-term weed control measures. The ordination analysis detected also an evident relationship between the weed composition and soil properties in the field. Some of these properties, e.g. soil pH, can be manipulated if neccessary.

Simultaneous analysis of several weed species with environmental factors and plotting of data gave a better community level description on weed incidence than regression analysis (ERVIÖ and SALONEN 1987) which rather provided a deeper but narrower insight into weed vegetation and individual weed species. Still, the ordination analysis should be regarded both as a hypothesis provoking and explaining approach. Nevertheless, it is appropriate to start the analysis of data from weed surveys with ordination analysis and to continue, if necessary, with regression analysis to solve more detailed hypotheses.

Acknowledgements. I am grateful to Drs Ben J. Post for arrangements during my visit at the VPO department of the Wageningen Agricultural University for two months in 1988 and to Dr Caspar Looman for supervising the application of ordination techniques and for valuable comments on the manuscript. Comments and corrections by Dr Jari Oksanen are also warmly acknowledged. My visit to the Netherlands was financed by the Academy of Finland and by the Research and Science Foundation of Farmos.

\section{References}

Albrecht, H. \& Bachthaler, G. 1988. Die Segetalflora zweier bayerischer Ackerstandorte 1986/87 im Vergleich zu Untersuchungsergebnissen von 1955/56 bzw. 1965. Z. Pfl.krankh. Pfl.shutz, Sonderh. 11: 163-174.

Andreasen, C., Streibig, J.C. \& HaAs, H. 1991. Soil properties affecting the weed distribution of 37 weed species in Danish fields. Weed Res. 31: 181-187.

BAYER 1992. Important crops of the world and their weeds. 2nd ed. BAYER AG. Leverkusen. 1681 p.

Birks, H.J.B. \& Austin, H.A. 1992. An annotated bibliography of canonical correspondence analysis and related constrained ordination methods 1986-1991. Univ. Bergen, Norway. 29 p.

Callauch, R. 1981. Vergleich der Segetalvegetation auf 'konventionell' und 'biologisch' bewirtschafteten Äckern in SONiedersachsen. Z. Pfl.krankh. Pfl.shutz, Sonderh. 9: 85-95.

Chancellor, R.J. 1985. Changes in the weed flora of an arable field cultivated for 20 years. J. Appl. Ecol. 22: 491-501.

Cousens, R., Marshall, E.J.P. \& Arnold, G.M. 1988. Problems in the interpretation of effects of herbicides on plant communities. BCPC Mono. No. 40 Environmental Effects of Pesticides. p. 275-282.

Dale, M.R.T., Thomas, A.G. \& John, E.A. 1992. Environmental factors including management practices as correlates of weed community composition in spring seeded crops. Can. J. Bot. 70: 1931-1939.

Erviö, L.-R. \& SAlonen, J. 1987. Changes in weed population of spring cereals in Finland. Ann. Agric. Fenn. 26: 201-226.

GAUCH, H.G. 1982. Multivariate analysis in community ecology. Cambridge University Press, Cambridge. 298 p.

Hallgren, E. 1989. Influence of different factors on the effect of spraying cereals in the spring with Oxitril 4 as regards weeds and grain yield. 2. Influence of crop, de- 
velopmental stage, prevailing conditions, geographical and climatic situation, soil type, organic content and $\mathrm{N}$-rate on weed stand and effect on weeds. Composition of weed stand at different relative yields. Proc. 29th Swed. Weed Contr. Conf. - Weeds and Weed Control, Uppsala. p. 39-74.

- 1993. Förändras ogräsfloran och verkan av ett ogräsmedel (Oxitril 4) med tiden?. Proc. 34:e svenska växtskyddskonferensen. Ogräs och ogräsbekämp., Uppsala. Rapp. p. 15-38.

HnL., M.O. 1973. Diversity and evenness: an unifying notation and its consequences. Ecology 54: 427-432.

Jensen, P.K. 1985. A review of yield responses to weed control in one thousand spring barley experiments. Proc. 1985 British Crop Prot. Conf. - Weeds 2: 687-692.

Jongman, R.H.G., Ter Braak, C.J.F. \& Van Tongeren, O.F.R. 1987. Data analysis in community and landscape ecology. Pudoc, Wageningen. 299 p.

JukOLA-Sulonen, E.-L. 1983. Vegetation succession of abandoned hay fields in central Finland - a quantitative approach. Univ. of Helsinki. Communic. Inst. Forestalis Fenn. 112.85 p. (Diss.)

Légère, A., Lemieux, C., Simard, R.R. \& Lapierre, C. 1993. Response of weed communities to fertility and tillage. Proc. 8th EWRS Symp. Quantitative Approaches of Weed and Herbicide Research. 1: 41-48.

LudwiG, J.A. \& ReYNOLDS, J.F. 1988. Statistical ecology - a primer on methods and computing. J. Wiley \& Sons, New York. 337 p.

MAнN, E.G. 1984. The influence of different nitrogen levels on the productivity and structural changes of weed communities in agroecosystems. Proc. 7th Int. Symp. on Weed Biology and Systematics., Paris. p. 421-429.

Mukula, J., Raatikainen, M., Lallukka, R. \& Raatikainen, T. 1969. Composition of weed flora in spring cereals in Finland. Ann. Agric. Fenn. 8: 59-109.

NeuruRer, H. 1965. Wandlungen in der Unkrautflora im Zuge von Standortsänderungen und als Folge von Bekämpfungsmassnahmen. Z. Pfl.krankh. Pfl.shutz, Sonderh. 3: 39-43.

PosT, B.J. 1986. Factors of influence on the development of an arable weed vegetation. Proc. EWRS Symp. Economic Weed Control. p. 317-325.

- 1988. Multivariate analysis in weed science. Weed Res. 28: 425-430.

PYŠEK, P. \& LEPŚ, J. 1991. Response of a weed community to nitrogen fertilization: a multivariate analysis. J. Vegetation Sci. 2: 237-244.

RaAtikainen, M. \& RaAtikainen, T. 1975. Heinänurmien sato, kasvilajikoostumus ja sen muutokset. Summary: Yield, composition and dynamics of flora in grassland for hay in Finland. Ann. Agric. Fenn. 14: 57-191.

- , Raatikainen, T. \& Mukula, J. 1978. Weed species, frequencies and densities in winter cereals in Finland. Ann. Agric. Fenn. 17: 115-142.
Rademacher, B., Koch, W. \& Hurle, K. 1970. Changes in the weed flora as the result of continuous cropping of cereals and the annual use of the same weed control measures since 1956. Proc. 10th Brighton Weed Conf. p. 1-6.

Reuss, H.-U. 1981. Untersuchung des Einflusses produktionstechnischer und ökologischer Faktoren auf die quantitative und qualitative Veränderung der standörtlichen Unkrautflora auf Ackerland. Technischen Universität München. 116 p. (Diss.).

SAlONEN, J. 1990. Analysis of weed data with advanced multivariate techniques. Nordic post-graduate course in crop production science. Garpenberg, Sweden. Mimeogr. 18 p. (Available at Agric. Res. Centre of Finland, Inst. Pl. Protect.)

- 1993. Performance of reduced herbicide doses in spring cereals. Agric. Sci. Finl. 2: (in press).

Siepel, H., Meuer, J., Mabelis, A.A. \& den Boer, M.H. 1989. A tool to assess the influence of management practices on grassland surface macrofaunas. J. Appl. Entomol. 108: 271-290.

ŠMILAUER, P. 1990. CANODRAW - a companion program to CANOCO for publication-quality graphical output. Microcomputer Power, Ithaca, New York. 33 p.

Streibig, J.C., Gottschau, A., Dennis, B., HaAs, H. \& Møl GAARD, P. 1984. Soil properties affecting weed distribution. Proc. 7th Int. Symp. on Weed Biology, Ecology and Systematics, Paris. p. 147-154.

Ter BRAaK, C.J. 1986. Canonical correspondence analysis: a new eigenvector technique for multivariate direct gradient analysis. Ecology 67: 1167-1179.

- 1987a. Unimodal models to relate species to environment. Wageningen Agricultural Univ. 152 p. (Diss.).

- 1987b. CANOCO - a FORTRAN program for Canonical Community Ordination. Microcomputer Power, Ithaca, New York. 95 p.

- 1987c. The analysis of vegetation-environment relationships by canonical correspondence analysis. Vegetatio 69: 69-77.

- 1990. Update notes: CANOCO version 3.10. Agricultural Mathematics Group, Wageningen. 35 p.

Wentworth, T.R., Conn, J.S., Skroch, W.A. \& Mrozek, E. 1984. Gradient analysis and numerical classification of apple orchard weed vegetation. Agric. Ecosyst. Envir. 11: 239-251.

\section{Manuscript received June 1993}

Jukka Salonen

Agricultural Research Centre of Finland

Institute of Plant Protection

FIN - 31600 Jokioinen, Finland 


\title{
SELOSTUS
}

\section{Kevätviljapeltojen rikkakasvillisuus ja rikkakasvien esiintymiseen vaikuttavien tekijöiden tarkastelu ordinaatioanalyysillä}

\author{
JUKKA SALONEN
}

Maatalouden tutkimuskeskus

Kevätviljapeltojen rikkakasvillisuutta analysoitiin ordinaatiomenetelmillä ja kuvattiin koordinaatistokuvilla. CANOCOohjelman monimuuttujamenetelmillä pystyttiin erottelemaan eri maantieteellisille alueille tyypillisiä rikkakasvilajeja ja niiden esiintymiseen vaikuttavia tekijöitä.

Viljelytekniset toimet kuten yksipuolinen viljanviljely ja jatkuva herbisidien käyttö suosivat mm. mataroiden, peippien, pihatähtimön ja peltoemäkin esiintymistä. Nämä lajit esiintyivät yleisimmin Lounais-Suomessa. Keski-Suomen tyypillisiä lajeja olivat mm. linnunkaali, juolavehnä ja kärsämöt. Maan happamuus ja maalaji olivat tärkeimpiä kasvualustaan liittyviä tekijöitä, jotka vaikuttivat rikkakasvuston koostumukseen. Jatkuva herbisidien käyttö oli merkittävin yksittäinen rikkakasvillisuuden koostumusta selittävä tekijä, joskin eri ympäristötekijöiden vaikutuksia rikkakasvilajeihin ei pystytty täysin erottamaan toisistaan.

Rikkakasvien keskimääräinen kasvutiheys oli $170 \mathrm{kpl} / \mathrm{m}^{2}$ (mediaani $124 \mathrm{kpl} / \mathrm{m}^{2}$ ). Rikkakasvien tuottama maanpäällinen ilmakuiva biomassa oli keskimäärin 320 kg/ha (mediaani 183 $\mathrm{kg} / \mathrm{ha}$ ). Rikkakasvien keskimääräinen kasvutiheys ei vaihdellut eri maalajeilla, mutta kasvit tuottivat enemmän biomassaa karkeilla kivennäismailla ja turvemailla kuin savimailla. Tehokkaimpia biomassan tuottajia olivat pillikkeet, jauhosavikka ja juolavehnä.

Rikkakasvikartoituksen lajisto koostui 33 ennalta valitusta lajista. Tyypillisesti kunkin pellon rikkakasvillisuus koostui muutamasta lajista. Yksittäisten lajien suhteellista runsautta kuvaavan N2-diversiteetin perusteella pelloilla esiintyi keskimäärin seitsemän kasvutiheydeltään $\left(\mathrm{kpl} / \mathrm{m}^{2}\right)$ merkittävää lajia. Lajisto jakautui lähes kaikilla viljelyksillä esiintyviin lajeihin (jauhosavikka, pillikkeet, orvokki) ja eri alueille tyypillisiin lajeihin. Ordinaatiokuvat antoivat selkeämmän kokonaiskuvan rikkakasvien esiintymisestä ja ympäristötekijöiden vaikutuksesta kuin aiemmin samasta aineistosta julkaistu regressiotarkastelu. 



\section{Efficacy of chemical weed control in spring cereals in Finland}

\author{
J. SALONEN AND L.-R. ERVIÖ \\ Agricultural Research Centre, Department of \\ Crop Science, SF-31 600 Jokioinen, Finland
}

Received 6 October 1987

Revised version accepted 12 January 1988

\section{Summary: Résumé: Zusammenfassung}

A national survey was conducted in Finland from 1982 to 1984 to determine the main weed species in spring cereals and the efficacy of herbicides on Finnish farms. The most common dicotyledonous weeds producing the highest biomass in spring cereals were Chenopodium album L., Galeopsis spp. L., Stellaria media (L.) Vill. and Lapsana communis $\mathbf{L}$. The main grass weed was Elymus repens (L.) Gould. The average reduction of weed biomass by herbicide treatment was $75 \%$. More reliable efficacy was obtained with herbicide mixtures than with MCPA alone.

\section{L'efficacité du désherbage chimique des céréales de printemps en Finlande}

Une enquête nationale a été conduite en Finlande de 1982 à 1984 pour déterminer les espèces principales présentes dans les céréales de printemps et l'efficacité des pulvérisations herbicides dans les fermes finnoises. Les dicotyledones les plus communes produisant la biomasse la plus élevée dans les céréales de printemps sont: Chenopodium album L.; Galéopsis spp. L., Stellaria media (L.) Vill. et Lapsana communis L. La graminée principale est Elymus repens (L.) Gould. La réduction de la biomasse adventice pour un traitement herbicide est en moyenne de $75 \%$. Une efficacité plus régulière est obtenue avec des mélanges herbicides plutôt qu'avec le MCPA seul.

\author{
Wirksamkeit der chemischen Unkrautbekämpfung \\ in Sommergetreide in Finnland
}

In den Jahren 1982 bis 1984 wurde in Finnland eine landesweite Erhebung über das Auftreten der wichtigsten Unkrautarten in Sommergetreide und die Wirksamkeit der Herbizidbehandlungen durchgeführt. Die häufigsten dikotylen Arten mit höchster Biomassebildung waren Chenopodium album L., Galeopsis spp. L., Stellaria media (L.) Vill. und Lapsana communis L. Unter den Gräsern war Elymus repens (L.) Gould am häufigsten. Die Biomasse wurde durchschnittlich um $75 \%$ durch Herbizidbehandlungen herabgesetzt. Herbizidmischungen waren wirksamer als MCPA allein.

\section{Introduction}

A turning point in the use of herbicides in Finland occurred in the early 1960s when an intensive advisory campaign caused a sharp increase in sales of herbicides (Mukula, 1965). Until then the estimated area of spring cereal fields treated with herbicides had been under $20 \%$ of the total but rose to $44 \%$ in 1965 (Mukula \& Ruuttunen, 1969).

At the moment, herbicides are the largest group of pesticides sold and used in Finland. They represent about $80 \%$ of the total quantity of active ingredients and about $70 \%$ of the monetary value of pesticides. The amount of cereal herbicides sold yearly is sufficient to treat $80-90 \%$ of the total cereal area in Finland (Hynninen \& Blomqvist, 1986, 1987). About $85 \%$ of spring cereals are sprayed with herbicides (Mukula \& Rantanen, 1987).

The efficacy of chemical weed control has been demonstrated in several field experiments (e.g. Aamisepp \& Wallgren, 1979; Kolbe, 1983) but our knowledge of the actual efficacy of herbicides in normal farm fields is not so complete. Environmental factors and application techniques, as well 
as competition of the crop, may influence the activity of herbicides (Maas, 1979).

The objectives of the present study were to establish which are the most common dicotyledonous weed species in spring cereals, and to determine the actual efficacy of chemical weed control that is achieved on Finnish farms. A detailed description of the weed flora in Finnish spring cereal fields has been given elsewhere (Erviö \& Salonen, 1987).

\section{Materials and methods}

The study was carried out as a part of a weed survey conducted in Finnish spring cereal fields from 1982 to 1984. The selection of farms, location of fields and sample areas in the fields is discussed in detail in a paper describing the changes of weed flora in Finland (Erviö \& Salonen, 1987). In this survey a total of 267 spring cereal fields were assessed, of which 12 fields were not sprayed with herbicides. Thus, 255 fields were relevant to the present study: 106 in barley, 96 in oats and 53 in wheat.

Four sample areas $180 \times 240 \mathrm{~cm}$ in size were randomly placed in each field. Half of each sample area was covered with plastic film during herbicide application. All decisions concerning weed control such choice of herbicide, time of spraying, and amount of water, were made by farmers. They used their own tractor sprayers.

During the second half of July aerial parts of weeds were collected from $0 \cdot 25-\mathrm{m}^{2}$ sample plots, both from untreated and treated sites of each sample area. The weeds were counted and the airdry weight was measured separately for each species.

The occurrence of the fifteen most frequent dicotyledonous weeds was recorded and the rest of the species were classified together in a group other dicots'. Results concerning Elymus repens and other grass weeds are also included.

Differences in the occurrence of weeds between the untreated and sprayed areas were analysed either with Student's $t$-test or by analysis of variance using square root transformed data. Square root transformation recommended by Steel \& Torrie (1960) was used to reduce the observed skewness in the experimental data.

The efficacy of herbicides was determined as a reduction of weed biomass compared with untreated sample plots in each field. Only those fields where each species occurred in untreated sample areas were taken into account in these calculations. The efficacy of control was classified into four classes according to Aamisepp \& Nilsson (1987).

\section{Results}

\section{Occurrence of weeds}

In untreated sample areas the density of weeds was on the average 172 weeds $\mathrm{m}^{-2}$, of which 151 were dicotyledonous species. The average dry weight of all weeds was $315 \mathrm{~kg} \mathrm{ha}^{-1}$ and that of dicotyledonous species $243 \mathrm{~kg} \mathrm{ha}^{-1}$, so that the latter represented $77 \%$ of the total weed biomass. In the treated sample areas the dicotyledonous weeds were only $48 \%$ of the total mass.

In untreated plots the fifteen most common dicotyledonous weed species represented $63 \%$ of the total weed mass (Table 1). The proportion of the main grass weed Elymus repens was almost $21 \%$. The group 'other dicots' comprised 17 annual or perennial species with a frequency less than $20 \%$.

Table 1 Frequencies of the 16 most common weeds and their average dry weight in untreated sample plots in 255 fields assessed

\begin{tabular}{|c|c|c|c|}
\hline \multirow[b]{2}{*}{ Weed species } & \multirow{2}{*}{$\begin{array}{c}\text { Frequency } \\
\qquad(\%)\end{array}$} & \multicolumn{2}{|c|}{ Dry weight } \\
\hline & & $\left(\mathrm{kg} \mathrm{ha}^{-1}\right)$ & $(\%)+$ \\
\hline Chenopodium album $\mathrm{L}$. & 88 & 44 & $14 \cdot 0$ \\
\hline Galeopsis spp. L. & 85 & 48 & $15 \cdot 2$ \\
\hline Viola arvensis Murr. & 85 & 8 & $2 \cdot 5$ \\
\hline Stellaria media (L.) Vill. & 80 & 22 & $7 \cdot 0$ \\
\hline \multicolumn{4}{|l|}{ Fallopia convolvulus (L.) } \\
\hline A. Lōve & 61 & 8 & $2 \cdot 5$ \\
\hline Erysimum cheiranthoides L. & 58 & 9 & $2 \cdot 9$ \\
\hline Lapsana communis $\mathbf{L}$. & 55 & 21 & $6 \cdot 7$ \\
\hline Myosotis spp. L. & 53 & 2 & 0.6 \\
\hline Polygonum aviculare $\mathrm{L}$. & 52 & 2 & 0.6 \\
\hline Spergula arvensis L. & 45 & 13 & $4 \cdot 1$ \\
\hline Fumaria officinalis L. & 43 & 6 & 1.9 \\
\hline Galium spp. L. & 35 & 3 & $0-9$ \\
\hline \multicolumn{4}{|l|}{ Tripleurospermum inodorum } \\
\hline Schultz Bip. & 31 & 2 & 0.6 \\
\hline Polygonum lapathifolium L. & 30 & 5 & 1.6 \\
\hline Lamium spp. L. & 25 & 5 & 1.6 \\
\hline Other dicotyledon speciesł & - & 44 & 14.0 \\
\hline Elymus repens (L.) Gould & 51 & 65 & $20 \cdot 6$ \\
\hline Other grass weeds & - & 8 & $2 \cdot 5$ \\
\hline
\end{tabular}

- The proportion of fields where species was observed out of 255 fields assessed.

+ From the average total biomass of weeds, $315 \mathrm{~kg} \mathrm{ha}^{-1}$

$\ddagger$ Including 17 annual or perennial species with frequency less than $20 \%$ 
Table 2 Effect of different herbicides on the dry weight of dicotyledonous weeds

\begin{tabular}{|c|c|c|c|c|}
\hline \multirow[b]{2}{*}{ Herbicide group } & \multicolumn{2}{|c|}{ Dry weight } & \multirow{2}{*}{$\begin{array}{l}\text { No. } \\
\text { fields }\end{array}$} & \multirow{2}{*}{$\begin{array}{c}\% \text { of } \\
\text { control }\end{array}$} \\
\hline & $\mathrm{kg} \mathrm{ha}^{-1}$ & s.e.m. & & \\
\hline MCPA & & & 97 & 65 \\
\hline Untreated & 272 & $35 \cdot 6$ & & \\
\hline Treated & 94 & $19 \cdot 3$ & & \\
\hline Dichlorprop/MCPA & & & 84 & 82 \\
\hline Untreated & 234 & $29 \cdot 6$ & & \\
\hline Treated & 43 & 7.8 & & \\
\hline Mecoprop/MCPA & & & 50 & 85 \\
\hline Untreated & 175 & $31 \cdot 4$ & & \\
\hline Treated & 27 & $5 \cdot 5$ & & \\
\hline Other herbicides & & & 24 & 81 \\
\hline Untreated & 293 & $60 \cdot 3$ & & \\
\hline Treated & 57 & 19.7 & & \\
\hline All fields & & & 255 & 75 \\
\hline Untreated & 243 & $18 \cdot 7$ & & \\
\hline Treated & 61 & $8 \cdot 2$ & & \\
\hline
\end{tabular}

Table 3 Percentage of fields in the different control efficacy classes

\begin{tabular}{lrccc}
\hline & \multicolumn{4}{c}{$\%$ of control } \\
\cline { 2 - 5 } & $\begin{array}{l}\text { Weak } \\
\text { Herbicide group }\end{array}$ & $\begin{array}{c}\text { Moderate } \\
40-70 \%\end{array}$ & $\begin{array}{c}\text { Good } \\
70-90 \%\end{array}$ & $\begin{array}{c}\text { Excellent } \\
>90 \%\end{array}$ \\
\hline MCPA & 11 & 21 & 30 & 38 \\
Dichlorprop/MCPA & 7 & 14 & 33 & 45 \\
Mecoprop/MCPA & 4 & 14 & 32 & 50 \\
Other herbicides & 0 & 17 & 38 & 46 \\
All fields & 8 & 17 & 32 & 44 \\
\hline
\end{tabular}

\section{Efficacy of herbicides on dicotyledonous weeds}

In total, 22 different products were used to control broad-leaved weeds. These were classified into four groups on the basis of their active ingredients (Table 2). The fourth group of 'other herbicides' included products containing mixtures of phenoxy acids/ioxynil/bromoxynil, phenoxy acids/clopyralid or chlorsulfuron as active ingredients. Due to the small number of fields in which these products were applied, a division of this group was not meaningful.

The average dose of active ingredient of MCPA was $1.2 \mathrm{~kg} \mathrm{ha}^{-1}$ when sprayed alone. The most common products were herbicides containing either dichlorprop or mecoprop (400 $\mathrm{g}^{-1}$ together with $200 \mathrm{~g}^{-1} \mathrm{MCPA}$. The average dose of these mixtures in spring cereals was 2.5-4.01 $\mathrm{ha}^{-1}$, and the average amount of water was $250 \mathrm{l}$ $\mathrm{ha}^{-1}$.
The average time interval between sowing and herbicide spraying was 26 days (12-43) and the weed samples were collected on average 38 days (12-46) after herbicide treatment.

The average total dry weight of dicotyledonous weeds was $243 \mathrm{~kg} \mathrm{ha}^{-1}$ in untreated, and $61 \mathrm{~kg}$ $\mathrm{ha}^{-1}$ in treated sample plots, respectively. Thus, the average control with herbicide treatment was $75 \%$ (Table 2).

Differences in the dry weights of weeds between untreated and treated plots were statistically significant $(P<0.001)$ with all herbicides, but differences between herbicide groups were not.

The efficacy of chemical weed control varied considerably in different fields and with different herbicides. The most unreliable control was obtained with products containing MCPA alone. The performance of herbicide mixtures was good or excellent in about $80 \%$ of fields assessed (Table $3)$.

The best effect was achieved against Chenopodium album and Erysimum cheiranthoides, which were easy to control with all herbicides. The weakest effect was observed against Lapsana communis with MCPA significantly $(P<0.05)$ lower than other herbicides (Table 4).

\section{Discussion}

According to the present survey the weed species, producing the most biomass in spring cereal fields in Finland were Chenopodium album, Galeopsis spp., Stellaria media, Lapsana communis and Elymus repens (Table 1).

Although Viola arvensis was common, its biomass production was usually quite low. In our study $V$. arvensis was controlled fairly well (Table 4), even though it is considered to be quite resistant to phenoxy herbicides (Fryer \& Makepeace, 1978). In Swedish field trials $V$. arvensis was observed to recover from herbicide treatment, and to be able to utilize the space obtained from other species controlled by spraying (Gummesson, 1983).

Results indicating the efficacy of control of the less frequent weed species (Table 4) should be interpreted with caution due to their random occurrence in sample plots. These weed species may have been absent either in untreated or treated sample plots.

The fifteen most common weed species were affected to different degrees by the herbicides 
Table 4 Effect of different herbicides on the biomass of dicotyledonous weed species

\begin{tabular}{lcccc}
\hline & \multicolumn{3}{c}{$\%$ of control } \\
\cline { 2 - 5 } Weed species & MCPA & Dichlorprop/MCPA & Mecoprop/MCPA & Other herbicides \\
\hline Chenopodium album & 87 & 92 & 93 & 99 \\
Galeopsis spp. & 71 & 71 & 83 & 95 \\
Viola arvensis & 79 & 84 & 91 & 79 \\
Stellaria media & 82 & 69 & 87 & 92 \\
Fallopia convolvulus & 69 & 89 & 55 & 83 \\
Erysimum cheiranthoides & 84 & 98 & 98 & 97 \\
Lapsana communis & 9 & 89 & 90 & 89 \\
Polygomum aviculare & 40 & 79 & 99 & 78 \\
Myosotis spp. & 28 & 76 & 32 & 59 \\
Spergula arvensis & 53 & 97 & 95 & 99 \\
Fumaria officinalis & 49 & 71 & 92 & 58 \\
Galium spp. & 32 & 62 & 94 & 66 \\
Tripleurospermum inodorum & 70 & 77 & 75 & 87 \\
Polygonum lapathifolium & 30 & 55 & 55 & 89 \\
Lamium spp. & 55 & & & \\
\hline
\end{tabular}

(Table 4). In most of the cases herbicide mixtures gave a better control than MCPA alone (see also Mukula \& Köylijärvi, 1965), but in many fields the dense crop stand already caused so much competition that MCPA alone was sufficient. This is in agreement with results by Fogelfors (1977).

In spring cereals herbicides can be applied from the three-leaf stage to shooting, but the right timing may be difficult under Finnish conditions where the development of plants is often very rapid (Pessala, 1976). Because of the weather the number of days suitable for spraying during that time may be restricted. Environmental factors are also recognized as a major cause of inconsistency in herbicide activity (Gerber, Nyffler \& Green, 1983; Caseley, 1984).

In a recent study (Luoma \& Lavonen, 1987) on the tractor sprayers of Finnish farms it was shown that $63 \%$ of sprayers had defects resulting in uneveness in application, which might have caused poor weed control also in some fields of our study.

The main reason for inadequate control in a number of fields was undoubtedly a wrong choice of herbicide (Table 2). Weeds like Galium spp., Lapsana communis and Polygonum spp. had been sprayed with MCPA, but they are known to be tolerant to MCPA (Fryer \& Makepeace, 1978). According to our study MCPA should be replaced by mecoprop/MCPA for the control of $L$. communis, and by dichlorprop/MCPA when Fallopia convolvulus or Myosotis spp. occurs (Table 4).

More than one-third of the fields surveyed were treated with MCPA alone. Sales statistics of herbicides in Finland also indicate that a great proportion of herbicides used against broadleaved weeds still consists of products containing MCPA alone (Hynninen \& Blomqvist, 1987).

The low rate herbicides like chlorsulfuron and metsulfuron-methyl are now available in Finland, and they are likely to replace phenoxy acids to some extent in the future. In general, these low rate herbicides have a wider spectrum of activity but they have also their weak points like Fumaria officinalis, Galium spp. and Viola arvensis (Aamisepp, 1986). Thus, their use may lead to botanical changes in cereal fields.

In conclusion, to obtain a satisfactory and economic weed control, the weed spectrum of each field should be considered more carefully before selecting a herbicide.

\section{Acknowledgments}

We wish to thank Mr Juha Mustonen and Mrs Katri Pahkala for their excellent work as leaders of the field studies during the first 2 years of this survey. Planning of the data collection and analysis by Mrs Liisa Mattila is also warmly acknowledged. The survey was financed by the Finnish Ministry of Agriculture and Forestry.

\section{References}

AAMISEPP A. (1986) Undersökningar av sulfonylurea-herbicider i stråsäd i svenska försök. Aktuellt fra Statens Fagtjeneste for Landbruket, 8, 229-237. 
AAMisepP A. \& Nusson H. (1987) De kemiska ogräsmedlens användningsområde och verkan mot ogräs. Ogräsnyckeln. Aktuellt fràn Lantbruksuniversitet, 354, 20-52.

AAMISEPP A. \& WALlgren B. (1979) Ogräs i stråsäd. Verkan av kemisk ogräsbekämpning och andra odlingsåtgärder, 19501978. Aktuellt fràn Lantbruksuniversitet, 280, 15.

CAsEley J. (1984) The influence of environmental factors on foliage-applied herbicides. NJF-seminarium $\mathrm{Nr}$ 58. 'Klimafaktorers inverkan pà herbicidernas effekt.

ERviô L.-R. \& SALONEN J. (1987) Changes in the weed population of spring cereals in Finland. Annales Agriculturae Fenniae, 26, 201-226.

Fogel.Fors H. (1977) The competition between barley and five weed species as influenced by MCPA treatment. Swedish Journal of Agricultural Research, 7, 147-151.

FRYER J.D. \& MAKEPEACE R.J. (1978) Weed Control Handbook. Volume II. 8th edn. Blackwell Scientific Publications, Oxford.

Gerber H.R., NyFfler A. \& GreEN D.H. (1983) The influence of rainfall, temperature, humidity and light on soil and foliarapplied herbicides. Aspects of Applied Biology, 4, 1-14.

Gummesson G. (1983) Chemical and non-chemical control changes in weed stand following different control measures. Weeds and Weed Control. 24th Swedish Weed Conference, pp. 234-245.

HYNNINEN E.-L. \& Blompvist H. (1986) Torjunta-aineiden myynti Suomessa 1985. Summary: Sales of pesticides in Finland in 1985. Kemia-Kemi, 13, 725-728.

HYNNINEN E.-L. \& BlomQvist H. (1987) Torjunta-aineiden myynti Suomessa 1986. Summary: Sales of pesticides in Finland in 1986. Kemia-Kemi, 14, 569-572.

KotBE W. (1983) Kulturpflanzenbau und Unkrautbekämpfung. Pflanzenschutz-Nachrichten Bayer, 36, 209-381.

LuOMA T. \& LAvoNEN A. (1987) Maatiloilla käytettãvien kasvinsuojeluruiskujen tekninen kunto. Kasvinsuojeluseuran 8. Kasvitauti- ja Tuhoeläinpäivä, pp. 6-10.

MA^s G. (1979) Einfluss von Umweltfaktoren und Spritztechnik auf die Wirkung von Herbiziden. Proceedings EWRS Symposium on The Influence of Different Factors on the Development and Control of Weeds, pp. 39-47.

Mukula J. (1965) Tilastoa rikkakasvihãvitteiden kāytôstä Suomessa. Pellervo, 66, 448-449.

Mukula J. \& KöYLuÄrvı J. (1965) Comparative studies with three herbicides, MCPA, MCPA plus 2,3,6-TBA and mecoprop for weed control in spring cereals. Annales Agriculturae Fenniae, 4, 256-276.

Mukula J. \& Rantanen O. (1987) Climatic risks to the yield and quality of field crops in Finland. I. Basic facts about Finnish field crops production. Annales Agriculturae Fenniae, 26, 1-18.

Mukula J. \& RuUtrunen E. (1969) Chemical weed control in Finland in 1887-1965. Annales Agriculturae Fenniae, 8, Supplement 1, 59-110.

Pessala B. (1976) Time of application of herbicides for Avena fatua control in spring wheat and barley. Proceedings 1976 British Crop Protection Conference-Weeds, pp. 39 - 46.

STEEL R.G.D. \& TORRIE J.H. (1960) Principles and Procedures of Statistics. McGraw-Hill, New York. 



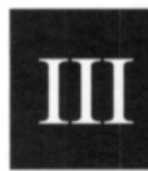





\section{Efficacy of reduced herbicide doses in spring cereals of different competitive ability}

\author{
J. SALONEN Agricultural Research Centre of \\ Finland, Institute of Plant Protection, SF-31600 \\ Jokioinen, Finland
}

Received 11 October 1991

Revised version accepted 6 April 1992

\section{Summary: Résumé: Zusammenfassung}

The effect of dose reduction on the efficacy of MCPA/mecoprop and MCPA/fluroxypyr mixtures in the control of broad-leaved weeds was studied in spring barley (Hordeum vulgare L.) and spring wheat (Triticum aestivum L.). Five crop densities were sown to obtain crop stands of different competitive ability. Halving the highest recommended dose decreased the control efficacy by $5-15$ percentage units, but still provided a good weed control. Further reduction of the dose resulted in high variation in efficacy. The level of weed suppression was mainly determined by the competitiveness of the crop, environmental conditions and weed spectrum with differential sensitivity of species to the herbicides. No changes in the weed infestation were detected after continuous use of low herbicide doses for 3 years. The seed bank of weeds in soil was higher after a wheat-dominated rotation than after a barley-dominated rotation.

Efficacité de doses réduites d'herbicides chez des céréales de printemps d'aptitudes à la compétitivé différentes

L'impact de la réduction des doses sur l'efficacité de mélange MCPA/mecoprop et MCPA/ fluroxypyr en matière de desherbage des dicotyledones a été étudié chez l'orge de printemps (Hordeum vulgare L.) et le blé de printemps (Triticum aestivum L.) 5 densités de culture ont été semées pour obtenir des cultures d'aptitudes à la compétitivité différentes. La réduction de moitié de la dose recommandée la plus élevée a réduit l'efficacité herbicide de 5 à $15 \%$ mais a encore fourni un bon résultat. Des réductions plus élevées de la dose ont conduit à de fortes variations dans l'efficacité. Le niveau de suppression des adventices était principalement déterminé par la compétitivité de la culture, les conditions environnementales et le spectre des adventices avec une sensibilité différentes des espèces aux herbicides. Aucun changement dans l'infestation en adventices n'a été observé après une utilisation continue de faibles doses d'herbicide pendant 3 ans. Le stock grainier d'adventices du sol était plus élevé après une rotation à dominante blé, qu'après une rotation à dominante orge.

Wirksamkeit reduzierten Aufwands von Herbiziden in Sommergetreide mit unterschiedlicher Konkurrenzkraft

In Sommergerste (Hordeum vulgare L.) und Sommerweizen (Triticum aestivum L.) wurde untersucht, wie die Reduzierung des Aufwands die Wirksamkeit von MCPA-Mecoprop- und MCPA-Fluroxypyr-Mischungen beeinflußt. Die Getreide wurden in 5 Dichten gesät, um Pflanzenbestände unterschiedlicher Konkurrenzkraft zu haben. Die Halbierung des höchsten empfohlenen Aufwands verminderte die Wirksamkeit um 5 bis 15 Prozentpunkte, ergab dennoch eine gute Unkrautbekämpfung. Eine weitere Reduzierung des Aufwands brachte sehr unterschiedliche Wirksamkeit. Der Grad der Unkrautunterdrückung wurde überwiegend durch die Konkurrenzkraft des Getreides, die Umweltbedingungen und das Unkrautspektrum mit gegenüber den Herbiziden verschieden empfindlichen Arten 
bestimmt. Nach 3 Jahren niedrigen Herbizidaufwands ließen sich Änderungen der Verunkrautung nicht erkennen. Der Unkrautsamenvorrat im Boden war nach einer weizendominierten Fruchtfolge größer als nach einer gerstendominierten.

\section{Introduction}

The encouraging results regarding the use of reduced herbicide doses in spring barley (Elbek Pedersen, 1978; Thonke, 1978), prompted many research projects in Scandinavia in order to study the possibilities of decreasing the total use of herbicides. As a result of decreased weed infestation in spring cereal fields (Erviö \& Salonen, 1987) and of inconsistent economic return from chemical weed control (Erviö et al., 1991), similar research was also considered necessary in Finland.

Weed management by applying reduced herbicide doses every year differs from the alternative approach of weed control thresholds. Thresholds have been extensively studied in Germany (Heitefuss et al., 1987). Gummesson \& Fogelfors (1990) suggested that in the long-term the annual use of reduced doses prevents the increase of the weed seed bank in soil more reliably than spraying only if certain thresholds are exceeded.

Herbicides for the control of broad-leaved weeds in cereals represent the most important group of pesticides used in Finland (Hynninen \& Blomqvist, 1990). Therefore, the reduction of chemical weed control in spring cereals would be economically and environmentally attractive. Thonke (1986) reviewed several promising results on the use of reduced herbicide doses. On the other hand, little is known about the long-term effects of successive applications of reduced doses, particularly on the soil seed bank of weeds and the effect on future weed infestations (Kudsk, 1989).

The objective of the present study on cereal herbicides was to investigate the efficacy levels achieved with lower dose rates than recommended in spring cereals. The long-term effects of continuous applications of reduced herbicide rates in crop stands of varying competitive ability were also studied.

\section{Materials and methods}

\section{Field trials}

Field trials with spring barley (cv. Arra) and spring wheat (cv. Luja) were performed at the Agricultural Research Centre of Finland during 1986-1988. The experiments were conducted in Jokioinen in Southern Finland $\left(61^{\circ} \mathrm{N}\right)$ and in Ylistaro in Central Finland $\left(63^{\circ} \mathrm{N}\right)$. The trials lasted 3 years with a barley-wheat-barley rotation at both sites and, additionally, with a wheat-barley-wheat rotation in Jokioinen. All three trials were established on clay soil, and 90 $\mathrm{kg} \mathrm{N} \mathrm{ha-1}$ was applied every year. The preceding crop at Jokioinen was grassland for cattle and spring barley in Ylistaro.

Field trials were laid out in a randomized complete-block design with a split-plot arrangement and four replicates. The main plots had five crop seed rates. The subplots, $3 \times 10 \mathrm{~m}$ in size, were subjected to treatments with two herbicide mixtures and three ascending dose rates up to the highest recommended commercial dose (Table 1). At Jokioinen the trials with barley and wheat were placed adjacent to each other in order to compare the competitive differences in the crops. Each trial consisted of 140 plots.

Commercial herbicide mixtures of MCPA 200 g a.i. $1^{-1} /$ mecoprop $400 \mathrm{~g}$ a.i. $\mathrm{I}^{-1}$ (Herbotal Plus) and MCPA $400 \mathrm{~g}$ a.i. $\mathrm{I}^{-1} /$ fluroxypyr $100 \mathrm{~g}$ a.i. $\mathbf{1}^{-1}$ (Starane M) contained salt-formulated phenoxy acids and ester-formulated fluroxypyr.

Herbicides were applied with a portable 3-mwide sprayer fitted with Hardi 4110-10 flat fan nozzles which gave $2001 \mathrm{ha}^{-1}$ spray solution at a pressure of $300 \mathrm{kPa}$. The treatment time (Table 2 ) was at the 3-to 4-leaf stage of the crop when

Table 1. Treatments in the factorial designed field trials in spring barley and spring wheat in Jokioinen and Ylistaro in 1986-1988

MAIN PLOT: SEED RATE (viable kernels $\mathrm{m}^{-2}$ )

Barley: 100, 300, 500 (normal), 700 and 900

Wheat: $200,400,600$ (normal), 800 and 1000

SUBPLOT: HERBICIDE AND RATE

\begin{tabular}{lcc}
\hline Treatment & I ha & kga.i. ha $^{-1}$ \\
\hline Untreated & 0 & 0 \\
MCPA/mecoprop & $1 \cdot 30$ & $0 \cdot 26 / 0 \cdot 52$ \\
MCPA/mecoprop & $2 \cdot 00$ & $0 \cdot 40 / 0 \cdot 80$ \\
MCPA/mecoprop & $4 \cdot 00$ & $0 \cdot 80 / 1 \cdot 60$ \\
MCPA/fluroxypyr & $0 \cdot 50$ & $0 \cdot 20 / 0 \cdot 05$ \\
MCPA/fluroxypyr & $0 \cdot 75$ & $0 \cdot 30 / 0 \cdot 08$ \\
MCPA/fluroxypyr & $1 \cdot 50$ & $0 \cdot 60 / 0 \cdot 15$ \\
\hline
\end{tabular}


Table 2. Application data from the field trials with spring barley and spring wheat at two locations in 1986-1988

\begin{tabular}{|c|c|c|c|c|c|c|}
\hline & \multicolumn{3}{|c|}{ Jokioinen } & \multicolumn{3}{|c|}{ Ylistaro } \\
\hline & 1986 & 1987 & 1988 & 10986 & 1987 & 1989 \\
\hline Application date & $18 \mathrm{JUN}$ & $24 \mathrm{JUN}$ & $10 \mathrm{JUN}$ & $19 \mathrm{JUN}$ & $23 \mathrm{JUN}$ & $3 \mathrm{JUN}$ \\
\hline Temperature $\left({ }^{\circ} \mathrm{C}\right)$ & 21 & 22 & 18 & 28 & 21 & 15 \\
\hline Relative humidity (\%) & 53 & 50 & 53 & 40 & 30 & 40 \\
\hline \multicolumn{7}{|l|}{ Days between } \\
\hline \multicolumn{6}{|l|}{ Spraying/assessment } & 30 \\
\hline barley & 29 & 31 & 31 & 33 & - & 31 \\
\hline wheat & 29 & 35 & 32 & - & 29 & - \\
\hline \multicolumn{7}{|l|}{ spraying/harvest } \\
\hline barley & 70 & 63 & 53 & 68 & - & 52 \\
\hline wheat & 99 & 94 & 83 & - & 91 & - \\
\hline \multicolumn{7}{|c|}{ Precipitation $(\mathrm{mm})$ between } \\
\hline $\begin{array}{l}\text { sowing/spraying } \\
\text { spraying/assessment }\end{array}$ & 7 & 75 & 27 & 21 & 64 & 53 \\
\hline barley & 55 & 29 & 22 & 73 & - & 49 \\
\hline wheat & 55 & 44 & 22 & - & 17 & - \\
\hline \multicolumn{7}{|l|}{ spraying/harvest } \\
\hline barley & 160 & 153 & 154 & 157 & - & 92 \\
\hline wheat & 272 & 227 & 223 & - & 137 & - \\
\hline \multicolumn{7}{|c|}{$\begin{array}{l}\text { Effective temperature sum } \\
\left(>5^{\circ} \mathrm{C}\right) \text { between }\end{array}$} \\
\hline $\begin{array}{l}\text { sowing/spraying } \\
\text { spraying/assessment }\end{array}$ & 203 & 182 & 226 & 279 & 195 & 154 \\
\hline barley & 326 & 297 & 406 & 331 & - & 367 \\
\hline wheat & 326 & 329 & 420 & - & 270 & - \\
\hline \multicolumn{7}{|l|}{ spraying/harvest } \\
\hline barley & 717 & 524 & 684 & 641 & - & 663 \\
\hline wheat & 790 & 635 & 956 & - & 611 & - \\
\hline
\end{tabular}

the weed seedlings were between the cotyledon and the four-leaf stage.

\section{Weed assessments}

The number of weed seedlings that emerged from the natural seed bank of the field was counted before spraying. Furthermore, the weed infestation was assessed 4 weeks after spraying and at harvest by counting seedling numbers and recording the air-dry biomass of weeds in a $0.25 \mathrm{~m}^{2}$ circle per plot. The herbicide efficacy against all broad-leaved weeds and separately against the most common weed species was determined by comparing the biomass of weeds in untreated and treated plots.

The subsequent effect of different treatments on the number of weeds which emerged by the 3- to 4-leaf stage of barley was studied at Jokioinen in 1989, 1 year after the three year trial period. At the same time, soil samples were taken from the plots sown at normal seed rate in order to compare the effects of different control intensities on the seed bank of weeds. Soil samples were taken from a depth of $0-20 \mathrm{~cm}$, and all weed seedlings that emerged during the following two growing seasons (1989-1990) were counted and removed from the sample pots which were kept in open-air greenhouses.

\section{Statistical analysis}

The biomass of weeds was transformed with the common logarithm $\log ^{10}(y+1)$ to achieve normal distribution and homogeneity of variances. The exponential pattern between weed infestation and crop density and herbicide rate was thus linearized. Similarly, the relative efficacy values were transformed with arcsin $(\sqrt{y})$ and the number of weeds with square root $(\sqrt{y})$ transformation before the data were subjected to analysis of variance and analysis of covariance using the density of crop as a covariate. The sum of squares was partitioned to orthogonal comparisons in order to test individual hypotheses. A linear regression model relating the weed infestation to the crop density and herbicide dose was used. Statistical analyses 
were performed with the Generalized Linear Models procedure of the SAS statistical package.

\section{Results and Discussion}

\section{Occurrence of weeds}

The beginning of the growing season was extremely dry in 1986 . On the other hand, the moisture conditions favoured the emergence of weeds in 1987 and in 1988, resulting in higher weed densities. At the time of treatment the density of weeds in untreated barley plots in Jokioinen was 48 weeds $\mathrm{m}^{-2}$ in 1986, 335 weeds $\mathrm{m}^{-2}$ in 1987 and 353 weeds $\mathrm{m}^{-2}$ in 1988 . In spring wheat the corresponding weed densities were 43,322 and 560 weeds $\mathrm{m}^{-2}$. In Ylistaro there were 111 weeds $\mathrm{m}^{-2}$ in barley in 1986,192 weeds $\mathrm{m}^{-2}$ in wheat in 1987 , and 415 weeds $\mathrm{m}^{-2}$ in barley in 1988. Accordingly, in most of the trials the density of weeds was higher than the average of 173 weeds $\mathrm{m}^{-2}$ in spring cereal fields in Finland (Erviö \& Salonen, 1987).

The most abundant weed species at Jokioinen were Chenopodium album L. and Galeopsis speciosa L., as is also the case in spring cereal fields in Finland (Erviö \& Salonen 1987). Stellaria media (L.) Vill. and Matricaria spp. L. were the main species at Ylistaro.

\section{Effect of crop density}

The crop density did not significantly affect the number of weed seedlings that emerged prior to spraying, but affected the weed infestation later in the growing season. In untreated plots the increase in crop seed rate improved the competitive ability of wheat more than that of barley (Fig. 1). However, the effect was usually marginal above the normal seed rates, as has also been shown by Håkansson (1975) and Erviö (1983).

Particularly in treated plots, the increase in crop seed rate above the recommended crop density gave an insignificant benefit in stunting the growth of the weeds. The suppression of weed growth with subnormal dose rates was clearly more efficient than the use of higher than recommended crop seed rates, as has also been suggested by Andersson (1984).

In each trial the above-ground biomass of weeds varied between crops $(P<0.05)$ in
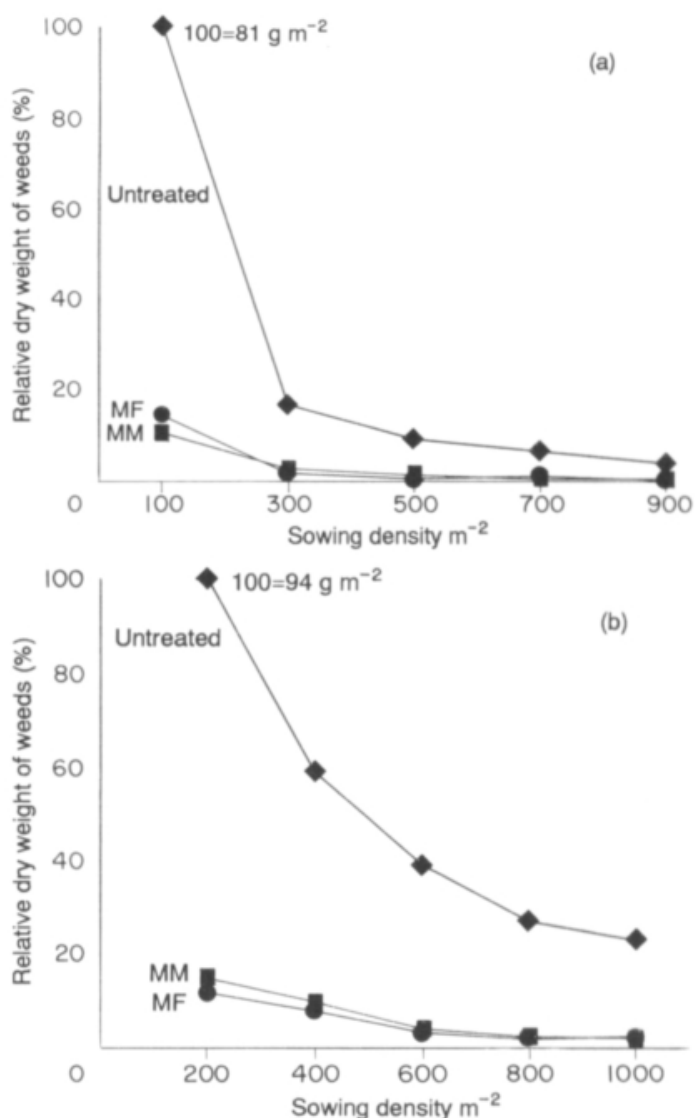

Fig. 1. Relationship between weed biomass and crop density of (a) barley and (b) wheat in 1986-88. Comparisons between the untreated plots and plots treated with either one-third dose of MCPA/mecoprop (MM) or one-third dose of MCPA/ flyroxypyr (MF) are presented.

Jokioinen, and was also explained with crop densities $(P<0.01)$, both 1 month after application (data not shown) and at harvest (Fig. 2). Decreased weed suppression with subnormal dose rates was to some extent compensated for by the increased crop seed rate.

\section{Herbicide efficacy}

The herbicide efficacy (Fig. 3), measured as a relative reduction in weed biomass compared to untreated plots within each crop density, did not vary significantly between crop densities. Therefore, the efficacy values were pooled across the five densities. The response curves shown in Fig. 3 represent three different control situations; in 1986, the weed infestation was low and dominated by susceptible species, whereas in 

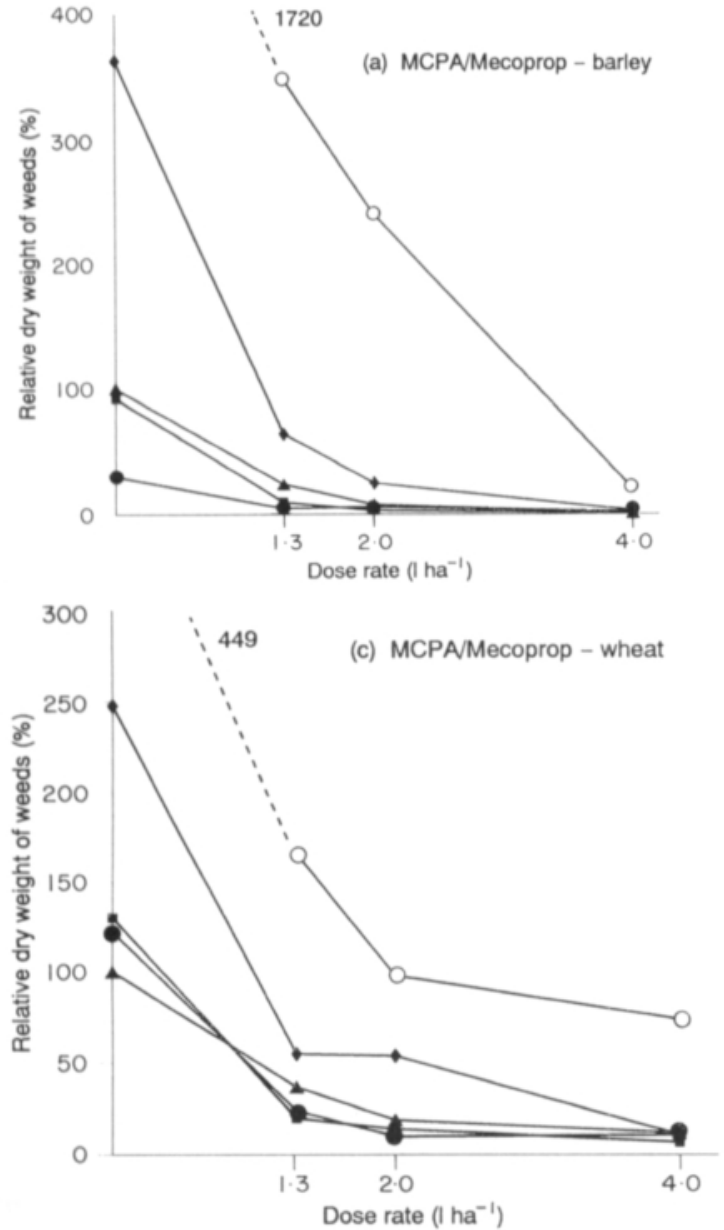

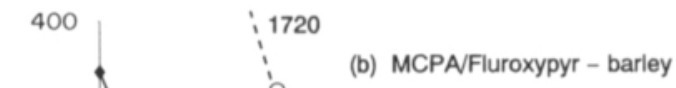

(b) MCPA/Fluroxypyr - barley
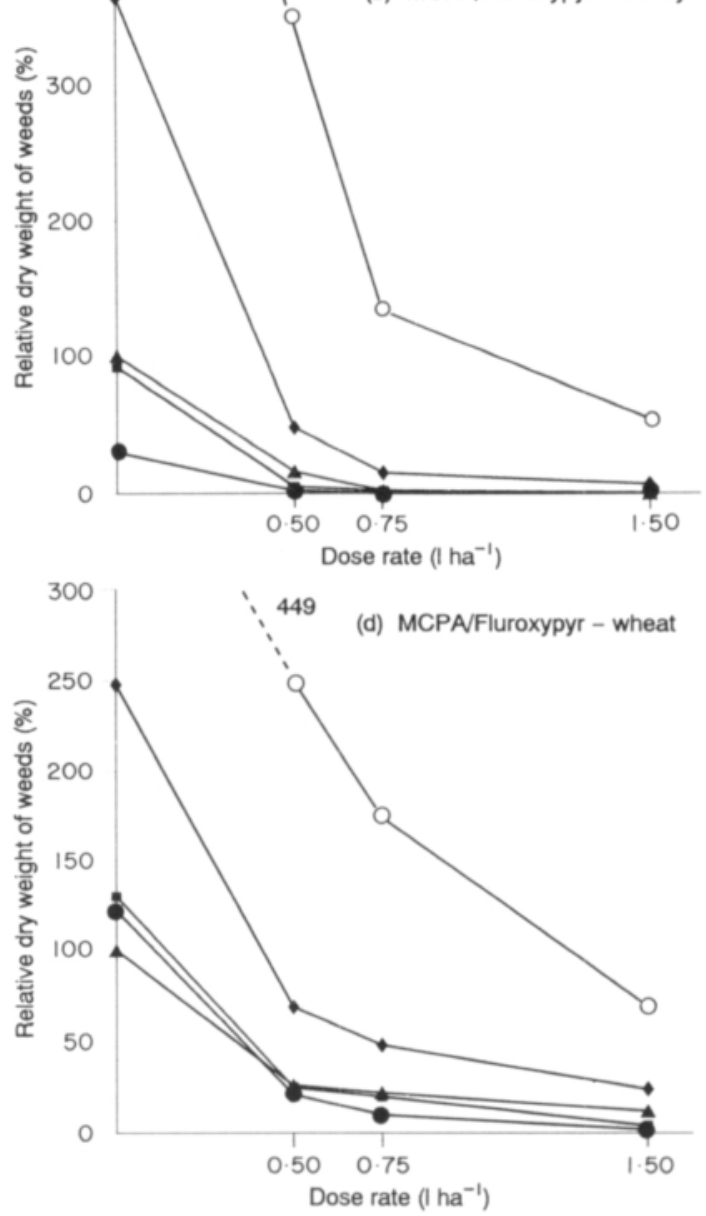

Fig. 2. Relative dry weight of broad-leaved weeds affected by crop density and herbicide rate. Relative value 100 equals the untreated plot at normal sowing density. Assessments were made at harvest time in Jokioinen. $(O=-400, \bullet=+400, \bullet=-200$, $\mathbf{v}=+200, \boldsymbol{\Delta}=$ normal [viable seeds of crop $\mathrm{m}^{-2}$ ].)

1988 there was a high weed infestation with a more tolerant weed spectrum resulting in lower efficacy. An intermediate situation occurred in 1987.

A parallel-line assay technique (Finney, 1979) with sigmoid dose-response curves, has been applied to describe the effects of herbicides (Streibig, 1988). The non-linear response was also found in our experiments (Figs 3 and 4), although our data were insufficient to cover the whole response curve. Within the dose interval used here, the linear model appeared, in some cases, to be a feasible approximation for describing the effect of dose rate on the biomass production of a mixed weed population.
Significant differences in efficacy between herbicides and their rates varied between trials. On average, higher control efficacy was achieved in Jokioinen, where the most abundant weed species were Chenopodium album $\mathrm{L}$. and Galeopsis speciosa L., compared to Ylistaro, where Stellaria media (L.) Vill., Matricaria spp. L. and Polygonum spp. L. were the main species.

\section{Effect of dose reduction}

The best weed control was achieved with the highest herbicide rate, but lower doses often provided good weed control. The dose reduc- 

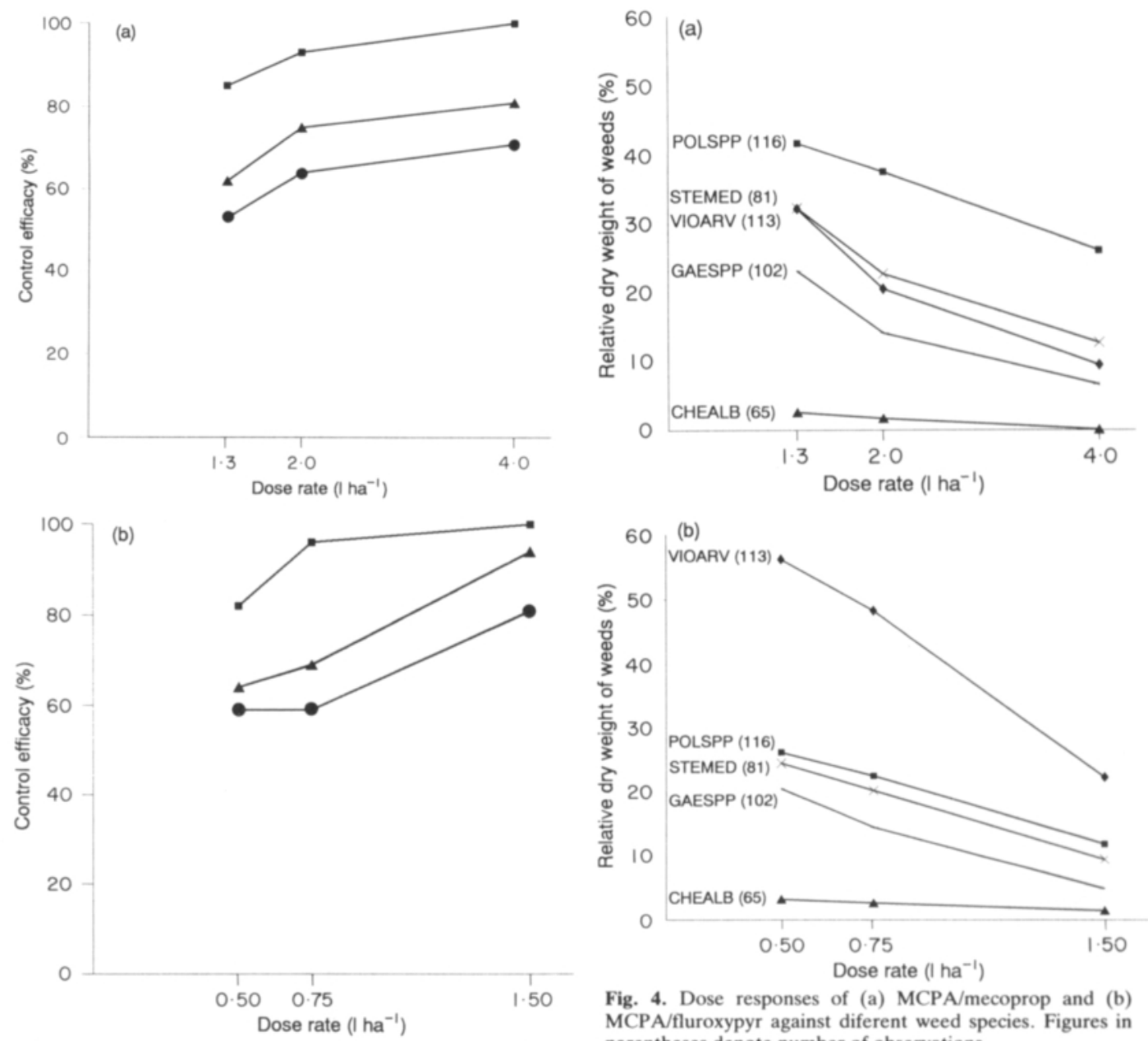

Fig. 3. Percentge efficacy of (a) MCP.A/mecoprop and (b) MCPA/fluroxypyr applied at three rates in different control situations in $1986(\mathbf{\bullet}), 1987(\boldsymbol{\Delta})$ and $1988(\bullet)$ (see text for explanation). Data express the reduction in weed biomass compared with untreated plots 4 weeks after spraying.

tion decreased the control efficacy of MCPA/ mecoprop less than that of MCPA/fluroxypyr (Fig. 3).

The average efficacy of herbicide mixtures at recommended rates in Finnish spring cereal fields is $80-85 \%$ (Salonen \& Erviö, 1987). With regard to the two products used in our trials, the intermediate dose rates of 2 and 0.751 (Figs 3 and 4) corresponded to a $25-30 \%$ reduction of the lowest recommended dose.

Halving the highest recommended dose rate decreased the efficacy by $5-15$ percentage units on average. With the one-third dose, which corresponded to a $50 \%$ reduction in the lowest recommended dose, the reduction of efficacy

Fig. 4. Dose responses of (a) MCPA/mecoprop and (b) MCPA/fluroxypyr against diferent weed species. Figures in parentheses denote number of observations.

was $10-25$ percentage units compared to the full dose. These results are in agreement with Swedish (Hagsand, 1983; Aamisepp, 1984; Lomakka, 1990) and German trials (Pallutt, 1991).

The susceptibility of weeds to reduced herbicide doses varied among species (Fig. 4). MCPA/fluroxypyr showed a linear response with all the five species studied, but the slope of the line varied between species. Differences in the control efficacy between the two herbicide mixtures were most clearly demonstrated against $V$. arvensis and Polygonum spp L.

Consequently, weed monitoring is a prerequisite for successful adjustment of dose rate, since the dose responses are species-specific (e.g. Elbak Jenson et al., 1989; Kudsk, 1989). The herbicides used in our experiment were 
Table 3. Regression coefficients (standard error S.E.) for the linear regression log $(\mathrm{Y}+1)=\mathrm{a}+\log \mathrm{bx}+\log \mathrm{cz}$ relating the biomass of weeds $(\mathrm{Y})$ at harvest to the crop density $\left(x\right.$ plants $\left.\mathrm{m}^{-2}\right)$ and the dose rate of herbicide $\left(\mathrm{z}^{\mathrm{h} \mathrm{ha}} \mathrm{h}^{-1}\right)$ in crop stands of spring barley and spring wheat treated with either MCPA/mecoprop or MCPA/fluroxypyr

\begin{tabular}{|c|c|c|c|c|}
\hline \multirow[b]{2}{*}{ Crop/trial } & \multicolumn{2}{|c|}{ MCPA/mecoprop } & \multicolumn{2}{|c|}{ MCPA/fluroxypyr } \\
\hline & $\begin{array}{l}\text { b(S.E.) } \\
\cdot 10 E-2\end{array}$ & c (S.E.) & $\begin{array}{l}\text { b (S.E.) } \\
\cdot 10 \mathrm{E}-2\end{array}$ & c (S.E.) \\
\hline \multicolumn{5}{|c|}{ Spring barley } \\
\hline JOK86 & $-0.121(0.019)$ & $-0.117(0.039)$ & $-0.114(0.020)$ & $-0.303(0.106)$ \\
\hline JOK87 & $-0.087(0.014)$ & $-0.136(0.032)$ & $-0.055(0.018)$ & $-0.127(0.109)$ \\
\hline JOK88 & $-0.112(0.014)$ & $-0.194(0.032)$ & $-0.098(0.013)$ & $-0.285(0.078)$ \\
\hline YLI86 & $-0.134(0.017)$ & $-0.153(0.033)$ & $-0.125(0.020)$ & $-0.142(0.099)$ \\
\hline YLI88 & $-0.169(0.014)$ & $-0.086(0.034)$ & $-0 \cdot 164(0 \cdot 011)$ & $-0.194(0.073)$ \\
\hline \multicolumn{5}{|c|}{ Spring wheat } \\
\hline JOK86 & $-0.049(0.038)$ & $-0.130(0.059)$ & $-0.096(0.035)$ & $-0.345(0.148)$ \\
\hline JOK87 & $-0.129(0.015)$ & $-0.099(0.030)$ & $-0 \cdot 158(0 \cdot 017)$ & $-0.380(0.097)$ \\
\hline JOK88 & $-0.099(0.023)$ & $-0.232(0.052)$ & $-0.120(0.020)$ & $-0.807(0.120)$ \\
\hline YLI87 & $-0.202(0.025)$ & $-0.096(0.050)$ & $-0.193(0.023)$ & $-0.163(0.119)$ \\
\hline
\end{tabular}

common broad-spectrum mixtures for cereals, and they were not selected on the basis of the weed species present at spraying.

Regression models of dose-responses should be developed for each herbicide against important weed species. However, the concept of effective dose (Streibig, 1989) is a function of many factors associated with the herbicide, the target weeds and environmental conditions, as well as interactions between these factors. This was also clearly demonstrated in our trials replicated in time and under different growth conditions.

The linear regression model (Table 3), including both the rate of herbicide and the crop density as independent variables, explained 13$80 \%$ of the variation in weed biomass at harvest in treated plots. The poor fit of the model was usually caused by the wide variation in data at the lower end of the dose range.

In practice, the use of lower dose rates than those employed in our trials seems unrealistic and unreliable due to the increasing variation in control efficacy against mixed weed populations. The effect of environmental factors, growth conditions and spray conditions on control also increases with decreasing dose rate.

\section{Subsequent effect on weed infestation}

Considerable differences in weed density were detected in untreated plots between the two crop rotations 1 year after the 3 year trial period. In the wheat-barley-wheat rotation the number of weed seedlings averaged $715 \mathrm{~m}^{-2}$ (S.E. 88, $n=20$ ), whereas in the barley-wheat-barley rotation it remained at the level of $336 \mathrm{~m}^{-2}$ (S.E. 50, $n=20$ ). On the other hand, in treated plots the mean density of weeds was 265 plants $\mathrm{m}^{-2}$ (S.E. $\left.7, n=240\right)$. No significant differences between herbicides and their rates were detected.

The weed biomass correlates closely with the seed production of weeds (Debeake, 1988; Wilson et al., 1988). Subnormal herbicide doses may not prevent weed seed production (Fogelfors, 1977). In our trials the measurement of the weed seed bank (Fig. 5) revealed no increase in the number of weed seeds in the soil

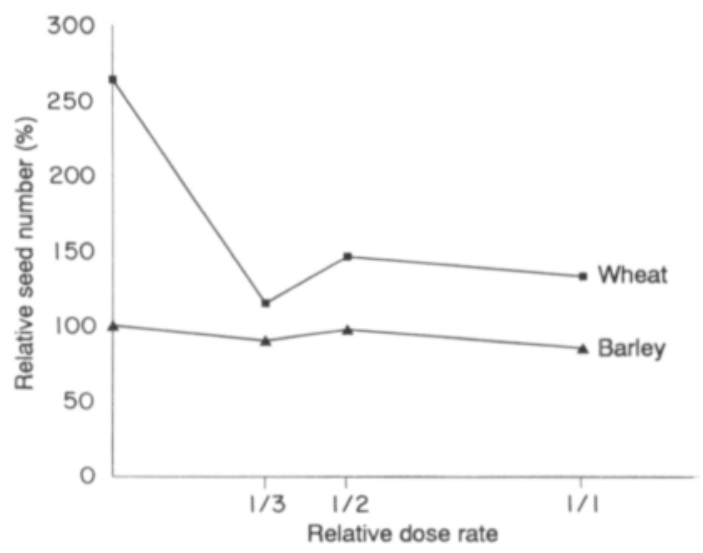

Fig. 5. Relative number of germinated weed seeds (untreated barley $=100$ ) in soil samples from crop stands of barley and wheat sown at normal seed rate. Samples were taken after 3 years of successive application of $\mathrm{MCPA} /$ mecoprop or MCPA/fluroxypyr with three dose rates (data pooled across herbicides. 
after continuous use of reduced herbicide doses for 3 years. Pedersen \& Rasmussen (1990) also found that a quarter of the normal dose of MCPA or chlorsulfuron adequately inhibited the seed production of weeds in barley stands compared with the normal dose.

The observations from the soil samples (Fig. $5)$ revealed that the seed reservoir of weeds in the field was significantly $(P<0.001)$ higher in the wheat-dominated rotation than in the barley-wheat-barley rotation. The highest seed bank was found in the untreated plots of wheat rotation.

In addition to lower competitiveness, spring wheat has a 20- to 30-day longer growth period than spring barley. Weeds effectively use this time for seed maturation and shedding before harvest. Therefore, weed control should be more efficient in wheat than in barley.

\section{Conclusions}

Chenopodium album and Galeopsis spp. are the most frequent and important weed species in spring cereals in Finland. Since they were effectively controlled even with the lowest dose rates, the possibility of making new detailed dose recommendations for cereal herbicides seems feasible.

Lowering the dose reveals differential susceptibility between weed species, and may favour more tolerant species within one growing season. The long-term changes in weed population are most efficiently prevented by choosing a herbicide according to the dominating weed species.

The reduction of herbicide dose to half or even less is often possible in well-defined weed/ herbicide situations in spring cereals. The complexity of affecting factors creates a decision problem which is most efficiently solved with computerized expert systems.

However, additional data on the competitive ability of the crop and enviromental factors are needed to develop a reliable advisory system for weed control, and particularly for the adjustment of adequate herbicide dose.

\section{References}

AAMISEPP A. (1984) Behovsprövad ogräsbekämpning i vårsäd. Slutrapport. Ogräs och Ogräsbekämpning, 25:e svenska orgräskonferensen, Uppsala, pp. 33-47.
ANDERSSON B. (1984) Utsãdesmängder och MCPA-doser i vårkorn. Ogräs och Ogräsbekämpning, 25:e svenska ogräskonferensen, Uppsala, pp. 49-58.

DEBAEKE P. (1988) Dynamique de quelques dicotyledones adventices en culture de cereale. II. Survie, floraison et fructification. Weed Research, 28, 265-279.

Elbaek Jensen P., Juhl Petersen E. \& Jorgensen H. (1989) Herbicider og vaekstreguleringsmidler under afprovning. Proceedings 6. Danske Plantevaernkonference/Ukrudt, pp. 62-93.

ElbeK Pedersen H. (1978) Use of reduced doses of herbicides in barley. Weeds and Weed Control, 19th Swedish Weed Conference, pp. B43-B49.

ERvio L.-R. (1983) Competition between barley and annual weeds at different sowing densities. Annales Agriculturae Fenniae, 22, 232-239.

ERVIO L.-R. \& SALONEN J. (1987) Changes in the weed population of spring cereals in Finland. Annales Agriculturae Fenniae, 26, 201-226.

ERvio L.-R., TANSKanen T. \& Salonen J. (1991) Profitability of chemical weed control in spring cereals. Annales Agriculturae Fenniae, 30, 199-206.

FINNEY D.J. (1979) Bioassay and the practice of statistical inference. International Statistical Review, 47, 1-12.

FogELFORS H. (1977) The competition between barley and five weed species as influenced by MCPA treatment. Swedish Journal of Agricultural Research, 7, 147-151.

Gummesson G. \& Fogelfors H. (1990) Möjligheter till minskad bekämpning av ogräs i stråsăd. 31:a Svenska Växtskyddskonferensen, Uppsala, pp. 60-68.

HAGSAND E. (1983) Utsãdesmãngder och kemisk ogräsbekämpning i sexradskorn i Norra Sverige. Röbäcksdalen meddelar, 1983:6, Umed, $19 \mathrm{pp}$.

HAKANSSON S. (1975) Grundläggande växtodlingsfrågor. I. Inflytande av utsädesmängden och utsädets horisontella fördelning på utveckling- och produktion i kortvariga vãxtbestånd. Sveriges Lantbruksuniversitet, Rapporter och Avhandlangar 33, Uppsala, 192 pp.

Hetrefuss R., GerowitT B. \& WaнmhofF W. (1987) Development and implementation of weed economic thresholds in the F.R. Germany. Proceedings of the 1987 British Crop Protection Conference - Weeds, pp. 1025-1034.

HYNNINEN E.-L. \& Blomovist H. (1990) Torjunta-aineiden myynti Suomessa 1989. Summary: Sales of pesticides in Finland in 1989. Kemia-Kemi, 17, 530-533.

KUDSK P. (1989) Experiences with reduced herbicide doses in Denmark and the development of the concept of factoradjusted doses. Proceedings of the Brighton Crop Protection Conference - Weeds, pp. 545-554

LOMAKKA L. (1990) Minimerad kemisk bekämpning av ogrăs vid ensidig kornodling i Norra Sverige. 31:a svenska växtskydds-konferensen, Ogräs och ogräsbekämpning, Uppsala, pp. 27-38.

PALLUTT B. (1991) Beiträge zur integrierten Unkrautbekämp fund im Getreideanbau. Dissertation, Akademie der Landwirtschafts-wissenschaften der DDR, Berlin, 129 pp.

Pedersen J.O. \& Rasmussen I.A. (1990) Herbiciders inflydelse på ukrudets fröproduktion. Proceedings 7. Danske Plantevaernskonference 1990, Ukrudt, pp. 73-83.

SAlonen J. \& ERVio L.-R. (1988) Efficacy of chemical weed control in spring cereals in Finland. Weed Research, 28, 231-235.

Streibig J.C. (1988) Herbicide bioassay. Weed Research, 28, $479-484$.

Streibig J.C. (1989) The herbicide dose-response curve and the economics of weed control. Proceedings of the Brighton Crop Protection Conference - Weeds, pp. 927-935.

THONKE K.E. (1978) Influence of growth factors when using reduced doses of hormone herbicides in barley. Weeds and Weed Control, 19th Swedish Weed Conference, pp. B51-B57. 
THONKE K. (1986) Muligheder for anvendelse af reducerede doseringer af herbicider. Proceedings 3. Danske Plantevaernkonferense/Ukrudt, pp. 117-124.

Wilson B.J., Peters N.C.B., Wright K.J. \& Atkins H.A.
(1988) The influence of crop competition on the seed production of Lamium purpureum, Viola arvensis and Papaver rhoeas in winter wheat. Aspects of Applied Biology, 18, 71-80. 



\section{Yield responses of spring cereals to reduced herbicide doses}

\author{
J. SALONEN Agricultural Research Centre of \\ Finland, Institute of Plant Protection, SF-31600 \\ Jokioinen, Finland
}

Received 11 October 1991

Revised version accepted 6 April 1992

\section{Summary: Résumé: Zusammenfassung}

Reduction of the dose of MCPA/mecoprop and MCPA/fluroxypyr mixtures to half or one-third of the recommended rates still provided good weed control efficacy in spring wheat (Triticum aestivum L.) and particularly in spring barley (Hordeum vulgare $\mathrm{L}$ ). The average yield of treated plots was $8 \%$ higher in wheat and $1 \%$ higher in barley compared with untreated plots. However, yield reductions were observed in $32 \%$ of wheat plots and in $43 \%$ of barley plots treated with herbicides. The yield responses were poorly correlated with the weed density of mixed weed flora at the time of spraying. No reliable threshold density for chemical weed control was found.

Réponses au rendement de céréales de printemps, à des doses d'herbicides réduites

La réduction de la dose de MCPA/mecoprop et MCPA/fluroxypyr à la moitié ou au tiers des taux recommandés a encore assuré une bonne efficacité herbicide chez le blé de printemps (Triticum aestivum L.) et spécialement chez l'orge de printemps (Hordeum vulgare L.). Le rendement moyen des parcelles traitées était de $8 \%$ plus élevé chez le blé et de $1 \%$ élevé chez l'orge que dans les parcelles non traitées. Cependant, des réductions de rendement ont été observées dans $32 \%$ des parcelles de blé et dans $43 \%$ des parcelles d'orge traitées aux herbicides. Les réponses du rendement étaient faiblement liées à la densité en adventices d'une flore mixte au moment du traitement. Aucune densité seuil-sérieuse pour le desherbage n'a été trouvée.

Ertragsbildung von Sommergetreide bei reduziertem Aufwand von Herbiziden

Eine Reduzierung des Aufwands von MCPAMecoprop- und MCPA-Fluroxypyr-Mischungen auf die Hälfte oder ein Drittel des empfohlenen Aufwands ergab in Sommerweizen (Triticum aestivum L.) und besonders in Sommergerste (Hordeum vulgare L.) noch eine gute Unkrautbekämpfung. Im Mittel war der Ertrag der behandelten Parzellen beim Weizen um $8 \%$ und bei der Gerste um $1 \%$ höher als in den unbehandelten, aber in $32 \%$ der Herbizidparzellen mit Weizen und in $43 \%$ der mit Gerste wurden Ertragsminderungen beobachtet. Die Ertragsbildung stand kaum in Beziehung zur Unkrautdichte zur Zeit der Behandlung. Es wurde keine verläßliche Schadensschwelle gefunden.

\section{Introduction}

Modern herbicides provide efficient control of weeds in cereals at a reasonable price compared with other economic inputs of cereal cultivation. Herbicides are primarily used to avoid yield loss by preventing weeds from interfering with cultivation, harvesting and marketing of grain (Elliott, 1978, 1980). However, environmental, economic and even political factors compel farmers to minimize their dependence on the use $=f$ herbicides.

Benefits from chemical weed control decrease with increasing yield level (Beer, 1979; Gummesson, 1987). The increasing crop yields (Mukula \& Rantanen, 1987) and the decreasing infestation of weeds (Erviö \& Salonen, 1987) in Finland gave an impetus to the evaluation of the 
present need for herbicides, particularly in spring cereals, which have a relatively high competitive ability. Spring cereals are grown on $53 \%$ of the cultivated field area in Finland (National Board of Agriculture, 1990).

The use of herbicides in spring cereals is not always profitable (e.g. Evans, 1969; Courtney \& Johnston, 1982; Aamisepp, 1984; Erviö et al., 1991). Substantial cost savings in chemical weed control are aimed at, either by using control thresholds (Heitefuss et al., 1987) or by applying reduced herbicide doses (Kudsk, 1989).

The objective of this study was to determine the yield responses of spring barley and spring wheat to chemical weed control, particularly with lower than recommended herbicide rates. The herbicidal efficacy in these field experiments has been described by Salonen (1992).

\section{Materials and methods}

A total of nine field trials were conducted in 1986-1988 with a six-row spring barley (cv. Arra) and spring wheat (cv. Luja) in Southern (Jokioinen) and Central (Ylistaro) Finland. Cereals were sown on clay soil using five seed rates: $100,300,500,700$ and 900 viable kernels of barley $\mathrm{m}^{-2}$ and $200,400,600,800$ and 1000 kernels of wheat $\mathrm{m}^{-2}$.

Trials were sown with a combined drill and fertilizer applicator which placed the NPK fertilizer $\left(90 \mathrm{~kg} \mathrm{~N} \mathrm{ha}^{-1}\right)$ between the crop rows under the seed bed at a depth of 7-9 $\mathrm{cm}$. The distance between crop rows was $12.5 \mathrm{~cm}$. The experimental plots were ploughed to a depth of $20 \mathrm{~cm}$ every autumn. All these measures followed the common farming practice in Finland.

Two herbicide mixtures at three dose rates were applied at the 3- to 4-leaf stage of the crop (Zadoks' scale 13-14) in order to control the broad-leaved weeds that emerged from the natural seed bank of the soil. The highest recommended rate of commercial herbicide mixture containing MCPA (200 g a.i. $\left.^{-1}\right)$ and mecprop (400 g a.i. $\mathrm{I}^{-1}$ ) (Herbotal Plus) was $4.01 \mathrm{ha}^{-1}$ and that of MCPA $\left(400 \mathrm{~g}\right.$ a.i. $\left.\mathrm{I}^{-1}\right)$ and fluroxypyr (100 g a.i. $^{-1}$ ) (Starane M) mixture was $1.51 \mathrm{ha}^{-1}$. In addition half and one-third rates were sprayed.

The experimental design was a split-plot with crop seed rate and herbicide treatments comprising main and sub-plot factors, respectively. There were four replicates. Grain yields were combined from an area of $21 \mathrm{~m}^{2}$ from the centre of each $3 \times 10 \mathrm{~cm}$ plot. The crop yield was adjusted to $15 \%$ moisture content. Moreover, the following yield components and quality parameters were determined: number of ears, number of kernels per ear, thousand kernel weight, bulk weight, moisture content at harvest and Hagberg's falling number of wheat.

\section{Results}

In 1987, the growing season was prolonged due to the poor weather conditions during the whole summer. Consequently, the spring wheat did not ripen sufficiently to be harvested, so that yield results from that year are not available. In other trials the crop yielded the average level for spring cereals in Finland.

The weed infestation varied considerably between years and sites (Table 1). The dominant weed species in the field trials were Chenopodium album L., Galeopsis spp. L., Stellaria media (L.) Vill. and Viola arvensis Murr.

Chemical weed control efficiently reduced the biomass of weeds at all herbicide rates applied (Fig. 1). The results from 1988 are shown as an example of good efficacy which, however, resulted in only slightly positive or even erratic yield response compared with the untreated plots. The yield level varied between the years and the trial sites. However, the yield response to weed control was similar at all yield levels (Fig. 2). Herbicides neither caused visible phytotoxicity to the crop nor affected to the dry weight of crop plants.

Table 1. Occurrence of weeds at harvest in unsprayed plots sown with normal seed rates

\begin{tabular}{rcc}
\hline & \multicolumn{2}{c}{ Weed infestation } \\
\cline { 3 - 4 } Year Site & $\begin{array}{c}\text { Density } \\
\left(\mathrm{m}^{-1}\right)\end{array}$ & $\begin{array}{c}\text { Biomass } \\
\left(\mathrm{g} \mathrm{m}^{-2}\right)\end{array}$ \\
\hline Spring barley & & \\
1986 JOK & 44 & 4 \\
YLI & 102 & 61 \\
1987 JOK & 322 & 10 \\
1988 JOK & 306 & 17 \\
YLI & 305 & 32 \\
Spring wheat & & \\
1986 JOK & 45 & 54 \\
1988 JOK & 301 & 112 \\
\hline
\end{tabular}

JOK $=$ Jokioinen, $\mathrm{YLI}=$ Ylistaro 

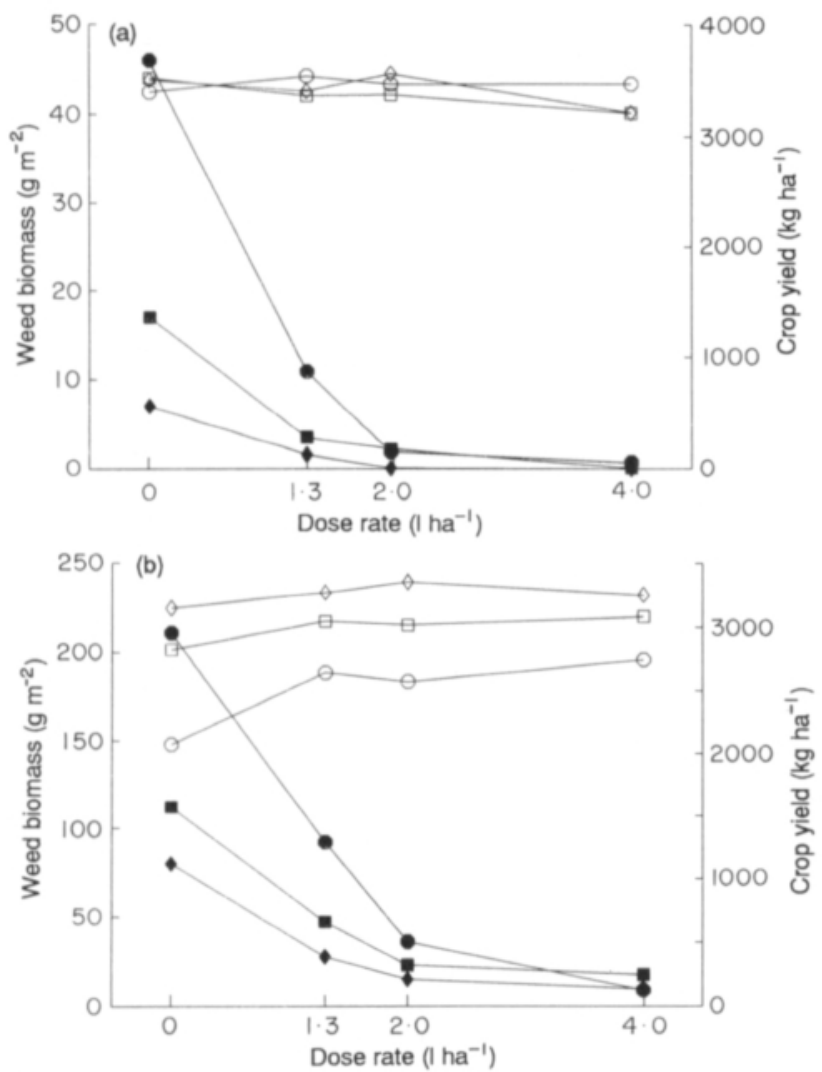

Fig. 1. Dose-response of crop yield (open symbols) and weed biomass (closed symbols) to the MCPA/mecoprop treatment in three growth densities of (a) spring barley and (b) spring wheat in Jokioinen in 1988. $(\mathrm{O})$ indicates the normal, ( $\square) 200$ seeds lower and $(\diamond) 200$ seeds higher sowing densities.

The proportional yield response to herbicide application compared with untreated crops varied between growth densities and trial sites (Fig. 3). Results were pooled across the years, since no significant interaction was found. The use of herbicides was naturally more profitable in crop stands of low growth density, and in Ylistaro, where the weed infestation was higher than in Jokioinen.

The reduced herbicide rates of Jokioinen gave higher yield increases than the recommended dose. However, the latter was the most economic at Ylistaro, where the weed population was more tolerant for the herbicides used in our trials.

When the lowest and highest crop densities were excluded from the calculations as inappropriate growth densities in practical farming, the yield response to chemical weed control in spring wheat averaged $202 \mathrm{~kg} \mathrm{ha}^{-1}$, corresponding to a yield increase of $8 \%$, and in spring barley $30 \mathrm{~kg} \mathrm{ha}^{-1}(1 \%)$. However, the yield response was negative in $32 \%$ of treated wheat plots and in $43 \%$ of barley plots.

The graphical plotting of results from separate trials (data not shown) revealed that yield responses to chemical weed control were poorly related to the weed density at the time of spraying. Yield responses to biomass production of weeds also remained fairly low even in 1988 (Fig. 1), when the weed infestation was highest. Spring barley in particular managed well, even without herbicides.

Even at a rather high weed infestation, as in 1988 , the benefit of using reduced herbicide doses was clearly demonstrated in spring wheat (Fig. 4). The highest yield increases were achieved with subnormal rates of MCPA/fluroxypyr, despite the fact that the lowest weed biomass was in plots treated with the recommended rate. 

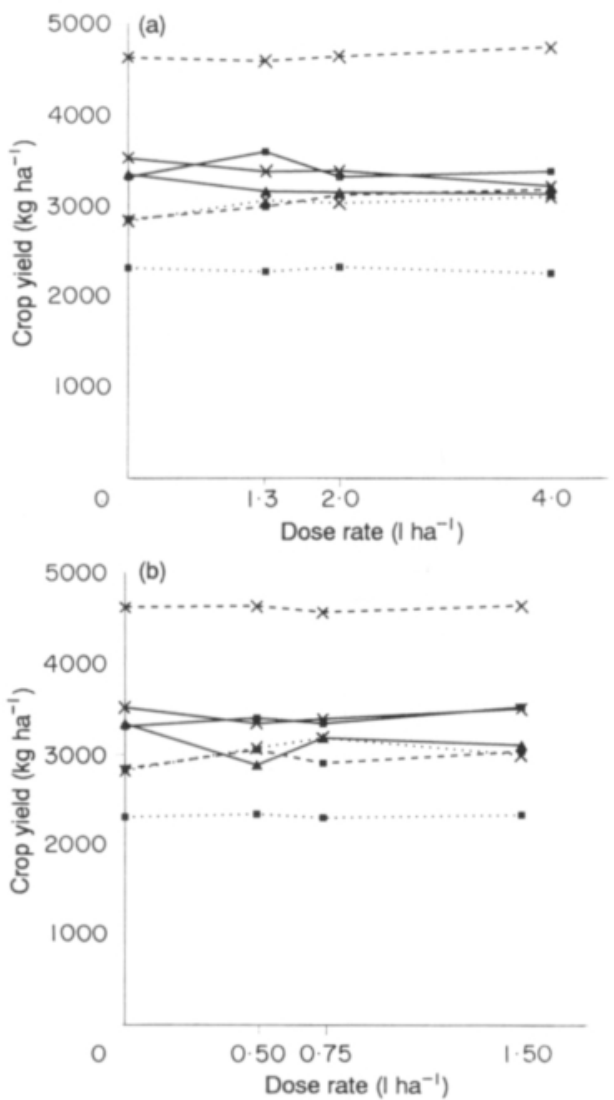

Fig. 2. Yield responses of spring barley ( - ) and spring wheat $(\cdots \cdots \cdot)$ in Jokioinen and spring barley (-....) in Ylistaro to the control of broad-leaved weeds with different doses of (a) MCPA/mecoprop and (b) MCPA/fluroxypyr in crop stands sown with normal seed rate (500 and 600 seeds $\mathrm{m}^{-2}$ of barley and wheat $(\mathbf{\square})=1986,(\boldsymbol{\Lambda})=1987,(\mathbb{\square})=1988$.

Statistically significant differences in yield parameters between untreated and treated plots were only detected in some cases (Table 2). No differences were found between herbicides and their dose rates.

\section{Discussion}

The density of weeds was rather low in 1986 due to the long dry period after sowing (Table 1). Otherwise, the weed infestation was higher than the average density of 173 weeds $\mathrm{m}^{-2}$ in Finnish spring cereals, but the main weed species in our trials corresponded well with the prevailing weed flora of cereal fields in Finland (Erviö \& Salonen, 1987). In the presentation of results, preference is given to data from 1988, when the weed infestation was highest.
The yield benefits for barley resulting from chemical weed control remained rather low. Similar results have been noted elsewhere (Courtney \& Johnston, 1986; Davies et al., 1989). Erviö et al. (1991) reported that the average yield increase with chemical weed control in spring cereal fields in Finland is $123 \mathrm{~kg}$ $\mathrm{ha}^{-1}$, and that $60 \%$ of treatments are profitable. In Norway, herbicides have decreased the crop yield in $25 \%$ of cereal fields (Fykse, 1991), and in Germany more than half of the herbicide applications in spring cereals have been unprofitable (Gerowitt et al., 1984).

Our trials were situated on clay soil where the harmful effects of weeds tend to be less than on other soil types (Kryger, 1985; Hallgren, 1989). In a comparison between soil types Jensen (1985) found that herbicide treatment resulted in yield decreases in $27 \%$ of all trials, but in $38 \%$ of the trials conducted on clay soils.

Relationships between crop yield and weed infestation have been described with different models (e.g. Cousens, 1985; Håkansson, 1991). However, when the weed infestation is manipulated by chemical control (Fig. 4), the effect of herbicide is also an important factor affecting the yield response of the crop (Brain \& Cousens, 1989; Streibig et al., 1989).

Yield responses to chemical weed control may be erratic, as in our trials with barley (Fig. 1), where the crop managed well in competition against weeds even without herbicide application. Obviously, the number of weeds assessed at the time of spraying is insufficient to describe the thresholds for chemical weed control in spring cereals (Bleiholder \& Nuyken, 1986). On the other hand, the use of thresholds seems to be more reliable in winter cereals (Heitefuss et al., 1987).

Yield results for spring wheat from 1988 (Fig. 4) showed that even at relatively high levels of weed infestation the benefit of efficient weed removal can be partly lost if unnecessarily high herbicide rates are applied, as was also shown by Aamisepp (1984), Andersson (1984), Gummesson (1988) and Davies \& Whiting (1990). The results from 1988 can be partly explained by the interaction of herbicide and long-lasting drought, which effectively suppressed the growth of weeds between herbicide application and weed assessment 1 month later.

At Jokioinen, the reduced herbicide doses provided a control efficacy of $70-90 \%$ and, on 

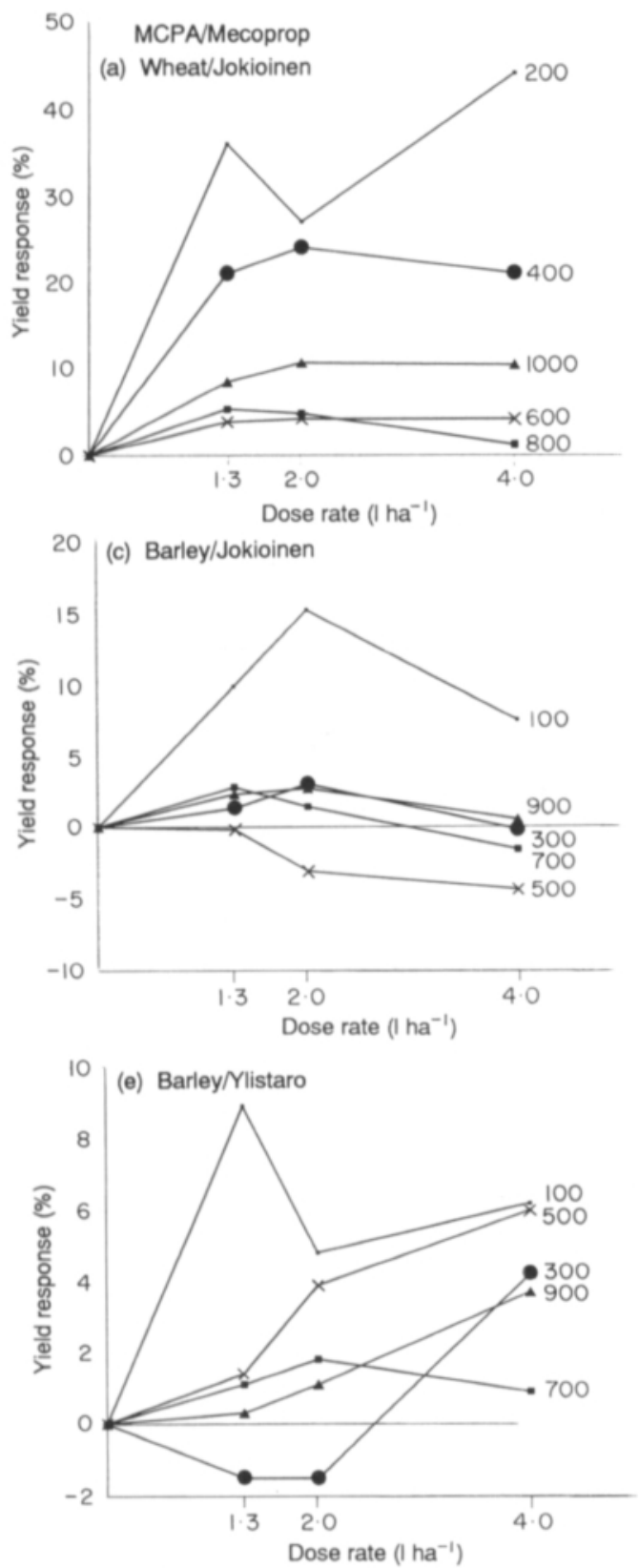

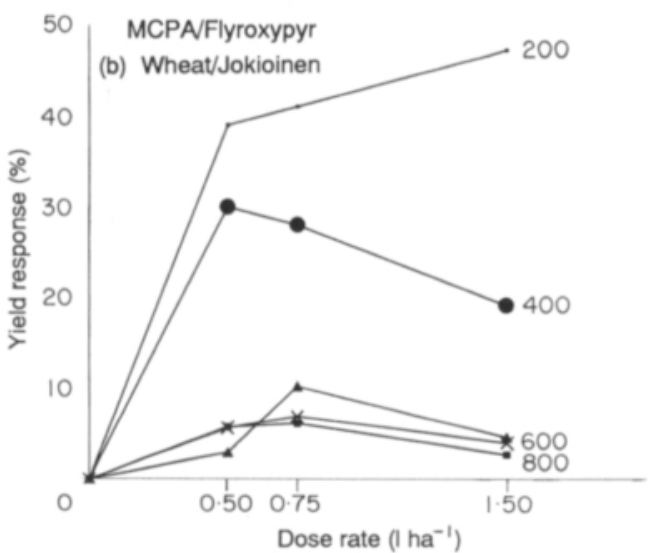

(d) Barley/Jokioinen
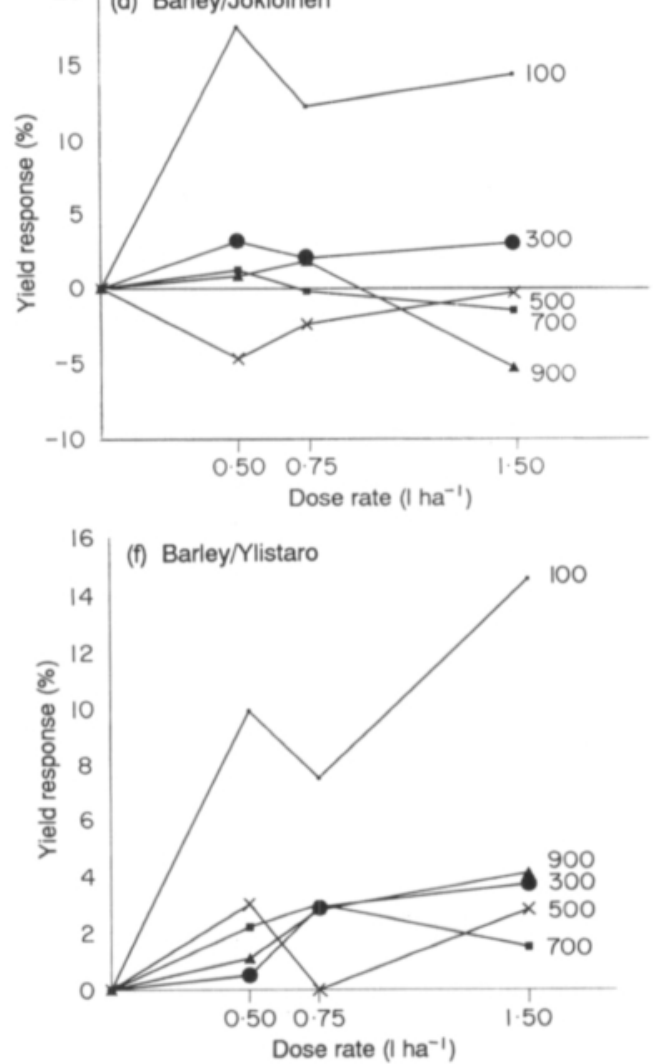

Fig. 3. Percentage yield response of spring cereals to weed control with different rates of MCPA/mecoprop and MCPA/ fluroxypyr. Mean values from 1986-1988 in different sowing densities.

average, gave higher yield increases than the highest dose, which suppressed weed infestation by more than $90 \%$. This is in agreement with the conclusions of Thonke (1986) who reviewed several Scandinavian field trials.

In Finland, the initial growth of spring cereals and weeds is rapid, and the outcome of their competition is difficult to predict. The dose reduction appears to be a more reliable weed control strategy than thresholds.

In conclusion, reduced rates of herbicides provided adequate control of broad-leaved weeds in terms of crop yield, although the efficacy was lower than that of recommended 
Table 2. Effect of herbicide treatment on yield parameters of crop sown with normal seed rate at Jokioinen

\begin{tabular}{|c|c|c|c|c|c|}
\hline Parameter & Year & Crop & Untreated & Treated & $P$-value \\
\hline Grain moisture & 1986 & Barley & $25 \cdot 0$ & $23 \cdot 6$ & $0 \cdot 009$ \\
\hline at harvest $(\%)$ & 1988 & Wheat & $24 \cdot 7$ & $21 \cdot 1$ & 0.001 \\
\hline \multirow{2}{*}{1000 kernel weight $(\mathrm{g})$} & 1986 & Wheat & 31.9 & $33 \cdot 4$ & 0.000 \\
\hline & 1988 & Wheat & $30 \cdot 1$ & $32 \cdot 1$ & 0.000 \\
\hline Bulk weight (kg) & 1988 & Wheat & $76 \cdot 2$ & $77 \cdot 5$ & $0 \cdot 000$ \\
\hline Number of ears $\left(\mathrm{m}^{-2}\right)$ & 1987 & Wheat & 490 & 584 & $0 \cdot 016$ \\
\hline Number of kernels/ear & 1987 & Barley & 23.9 & $28 \cdot 3$ & 0.037 \\
\hline
\end{tabular}

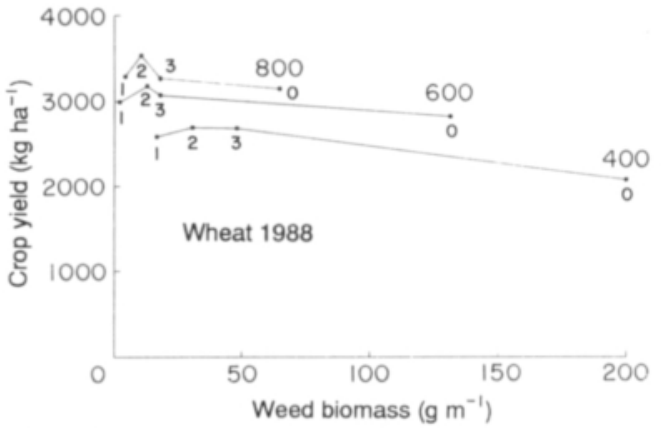

Fig. 4. Relationship between the wheat yield and the biomass of weeds at harvest in three crop densities ( 400 to 800$)$. The infestation levels of weeds were achieved with MCPA/ fluroxypyr applied at the recommended (1), half (2) and onethird dose (3). 0 indicates untreated plots.

doses. High dose rates were profitable only if less susceptible weed species occurred or in crop stands of low competitiveness. Particularly in barley sown at recommended seed rates, low dose rates seem to be a feasible way of reducing the use of herbicides by at least $25-30 \%$. Under favourable conditions a dose reduction of $50 \%$ or more may be possible.

\section{References}

AAMISEPP A. (1984) Behovsprövad ogräsbekämpning i vårsäd. Slutrapport. Ogräs och Ogräsbekämpning, 25:e svenska ogräskonferensen, Uppsala, pp. 33-47.

ANDERSSON B. (1984) Utsädesmängder och MCPA-doser i vårkorn. Ogräs och Ogräsbekämpning, 25:e svenska ogräskonferensen, Uppsala, pp. 49-58.

BEER E. (1979) Ermittlung der Bekämpfungsschwellen und wirtschaftlichen Schadensschwellen von monokotylen und dikotylen Unkräutern in Winterweizen und Wintergerste anhand von Daten aus der amtlichen Mittelprüfung. Dissertation. University of Göttingen.

BleiHOlder H. \& Nuyken W. (1986) Neue Ansätze zur Darstellung und interpretation des Zusammenhanges zwischen den Deckungsgrad der Unkräuter und dem Ertrag von Getreide. Proceedings of the EWRS Symposium 1986, Economic Weed Control, pp. 61-68.

BraIn \&. \& Cousens R. (1989) An equation to describe dose responses where there is stimulation of growth at low doses. Weed Research, 29, 93-96.
Courtney A.D. \& Johnston R.T. (1982) The influence of competitive stress and the application of a herbicide, based on 2,4-DP/MCPA, on the components of yield in spring barley. Aspects of Applied Biology 1, 239-246.

COURTNEY A.D. \& JoHNSTON R.T. (1986) An assessment of weed populations and yield responses on spring barley subjected to a programme of reduced herbicide usage. Proceedings of the EWRS Sympsoium 1986, Economic Weed Control, pp. 301-308.

COUSENS R. (1985) A simple model relating yield loss to weed density. Annals of Applied Biology, 107, 239-252.

DAvies D.H.K. \& Whiting A.J. (1990) Effect of reduced herbicide dose on weed growth and crop safety in cereals and consequences for grain quality and harvesting. Proceedings of the EWRS Symposium 1990, Integrated Weed Management in Cereals, pp. 331-336.

DAviEs D.H.K., Whiting A.J. \& WhYtock G.M. (1989). Yield responses to herbicide use and weed levels in winter wheat and spring barley in Scottish trials and consequences for economic models. Proceedings of the 1989 Brighton Crop Protection Conference - Weeds, pp. 955-960.

Eluotr J.G. (1978) The economic objectives of weed control in cereals. Proceedings of the 1987 British Crop Protection Coference - Weeds, pp. 829-841.

ELuotr J.G. (1980) The economic significance of weeds in the harvesting of grain. Proceedings of the 1980 British Crop Protection Conference - Weeds, pp. 787-797.

ERvio L.-R. \& SAlonen J. (1987) Changes in the weed population of spring cereals in Finland. Annales Agriculturae Fenniae, 26, 201-226.

Ervio L.-R., TANSKanen T. \& Salonen J. (1991) Profitability of chemical weed control in spring cereals. Annales Agriculturae Fenniae, 30, 199-206.

Evans S.A. (1969) Spraying of cereals for the control of weeds. Experimental Husbandry, 18, 102-109.

FYKSE H. (1991) Skadetersklar for ugras. Norsk Landbruksforsking, Suppl. 10, 40-43.

Gerowitt B., Bodendorfer H. \& HeItefuss R. (1984) Zur Wirtschaftlichkeit des Herbizideinsatzes im Getreide Auswertung von Versuchen des Pflanzenschutzdienstes den Jahren 1977-81. Zeitschrift für Pflanzenkrankheiten und Pflanzenschutz, Sonderheft X: pp. 127-135.

GuMMESsON G. (1987) Kan kemisk bekämpning mot ogräs halveras med bibehållen lönsamhet. Växskyddsrapporter, Jordbruk, 42, 19-30.

GuMmesson G. (1988) Mãngden ogräsmedel kan mınskas genom bättre anpassning av dosen. Värskyddsrapporter, Jordbruk, 49, 13-20.

HALLgRen E. (1989) Influence of different factors on the effect of spraying cereals in the spring with Oxitril 4 as regards weeds and grain yield. 2. Influence of crop, developmental stage, prevailing conditions, geographical and climatic situation, soil type, organic content and $\mathrm{N}$-rate on weed stand and effect on weeds. Composition of weed stand at different relative yields. Weeds and Weed Control. 29th Swedish Weed Control Conference, pp. 39-74.

HÁkANSSON S. (1991) Growth and competition in plant 
stands. Swedish University of Agricultural Sciences, Crop Production Science 12, Uppsala, 241 p.

HeITEFusS R. GerowitT B. \& WAнMHOFF W. (1987) Development and implementation of weed economic thresholds in the F.R. Germany. Proceedings of the 1987 British Crop Protection Conference - Weeds, pp. 10251034.

JENSEN P.K. (1985) A review of yield responses to weed control in one thousand spring barley experiments. Proceedings of the 1985 British Crop Protection Conference -Weeds, pp. 687-692.

KrYGer J. (1985) Muligheder for fastsaettelse af skadetaerskler i vårbyg. 2. Danske Plantevaernkonkonference/Ukrudt, pp. 203-216.

KUDSK P. (1989) Experiences with reduced herbicide doses in Denmark and the development of the concept of factoradjusted doses. Proceedings of the Brighton Crop Protection Conference - Weeds, pp. 545-554.
MuKULA J. \& RANTANEN O. (1987) Climatic risks to the yield and quality of field crops in Finland. I. Basic facts about Finnish field crops production. Annales Agriculturae Fenniae, 26, 1-18.

NATIONAl BoARd of Agriculture (1990) Monthly review of Agricultural Statistics, n:o 7:23. Helsinki.

SALONEN J. (1992) Efficacy of reduced herbicide doses in spring cereals of different competitive ability. Weed Research, 32, 000-000.

STREIBIG J. (1983) Ukrudtssprojtning og merudbytte i korn. Ugeskrift for Jordbrug, 128, 811-816.

Streibig J.C., Combellack J.H., Pritchard G.H. \& RICHARDSON R.G. (1989) Estimation of thresholds for weed control in Australian cereals. Weed Research, 29, 117-126.

THONKE K.E. (1986) Muligheder for anvendelse af reducerede doseringer af herbicider. 3. Danske Plantevaernkonference/Ukrudt pp. 2117-124. 




\title{
Performance of reduced herbicide doses in spring cereals
}

\begin{abstract}
JUKKA SALONEN
SALONEN, J. Performance of reduced herbicide doses in spring cereals. Agric. Sci. Finl. 2: 000-000. (Agric. Res. Centre of Finland, Inst. PI. Prot., FIN-31600 Jokioinen, Finland.)

The consequences of dose reduction of three new herbicide formulations were studied for the control of annual broad-leaved weeds in fields of spring barley (Hordeum vulgare L.) and spring wheat (Triticum aestivum L.). The herbicide formulations were MCPA/mecoprop-P, MCPA/dichlorprop-P and MCPA/fluroxypyr. The efficacy of the lowest recommended dose and a $30 \%$ lower rate were tested and compared with the reference herbicide tribenuron-methyl. Trials were conducted at seven sites for three years. Considerable annual fluctuations in weed infestation were recorded. Although the dose reduction occasionally caused considerable decline in control (on \%-scale), suppression of weed biomass was still satisfactory in most of the trials. On average, a 75\% reduction of weed biomass in spring barley and an $83 \%$ reduction in spring wheat were achieved with reduced herbicide doses. Use of reduced herbicide doses for three years in the same fields caused neither a significant increase in weed infestation nor changes in the species composition of weed populations compared with treatments at recommended rates of application. There was a significant difference in biomass production between weed species. Consequently, the total biomass production of annual dicotyledonous weeds correlated only weakly $(r=0.48)$ with the total weed density. Even in untreated plots the weed biomass at harvest constituted, on average, only $3.1-3.6 \%$ of the total vegetative biomass of crop stands. Thus, the crop yield responses to chemical weed control remained low.
\end{abstract}

Key words: spring barley, spring wheat, broad-leaved weeds, MCPA/mecoprop-P, MCPA/dichlorprop-P, MCPA/fluroxypyr, tribenuron-methyl

\section{Introduction}

Reduced herbicide doses have provided adequate control of broad-leaved weeds in many recent cereal experiments (e.g. BAANDRUP and BALLEGAARD 1989, DAVIES et al. 1989, Fogelfors 1990, KEMMER and HURLE 1990, PROVEN et al. 1991, SALONEN 1992a). At present, political Action Plans stipulate the reduction of pesticide use in the Nordic countries (THONKE 1991, Ympäristöministeriö 1992). Reduction of herbicide doses is one of the measures suggested and studied to achieve this objective.

In the Nordic countries (Denmark, Finland, Norway, Sweden), herbicides represent $60-80 \%$ of total pesticide use (THONKE 1991, MARKKULA et al. 1990). Herbicides are commonly used to control broad-leaved weeds in fields of small-grain cereals, which represent the most widely cultivated crops. Therefore, special attention is paid to optimization of herbicide use in cereal fields as cereals are probably able to out-compete weeds even at low rates of herbicide application. 
The recommended herbicide doses given on the product labels are normally suggested by chemical companies and then officially tested and approved by the relevant national authorities. The recommended "normal" dose implicitly ensures reliable weed control in most situations. The use of factoradjusted doses is, however, emphasized by the extension service and computer-based advisory systems (KUDSK 1989, BAANDRUP and BALLEGAARD 1989, JENNÉUS 1991).

Formulated mixtures of MCPA/dichlorprop and $\mathrm{MCPA} /$ mecoprop are commonly used in spring cereal crops in Finland (HYNNINEN and BLOMQVIST 1993). To date, the commercial formulations of phenoxypropionic acids, dichlorprop and mecoprop, have been mixtures of two optical isomers, $\mathrm{R}^{(+)}$and $\mathrm{S}^{(-)}$. However, only the $\mathrm{R}^{(+)}$isomer is an active part of herbicide. Recently, these isomers have been separated, and formulations containing only the active isomer have been developed (SQUIRES et al. 1987). Replacement of conventional racemic isomers by the new active isomers, dichlorprop-P and mecoprop-P, results in approximately $50 \%$ reduction in the use of the active ingredients, dichlorprop and mecoprop. The first commercial products containing active isomers were registered in Finland in 1992.

The purpose of this study was to investigate possibilities for reducing the lowest recommended application rates of the new cereal herbicides by $30 \%$. The risk of failure was assessed, and the consequences of continuous use of reduced herbicide doses on weed infestation were studied. Furthermore, crop yield responses to chemical weed control were measured.

\section{Material and methods}

Field experiments were conducted at seven experimental stations of the Agricultural Research Centre. Four stations (Anjalankoski (KYM), Jokioinen (RKA), Kokemäki (SAT) and Mietoinen (LOU)) are located in southern Finland and three stations (Mouhijärvi (SAH), Pälkäne (HÄM) and Ylistaro (EPO)) in central Finland. The same trial protocol was used for three years, 1989-1991, in spring bar- ley and spring wheat monocultures in the same field. At each site there was one spring wheat (cv. 'Luja') trial and at four sites (EPO, KYM, LOU, RKA) there was a spring barley (cv. 'Pohto') trial. Thus, during the 3-years of experimentation there were in total 21 spring wheat trials and 11 spring barley trials.

The experiments were established in 1989 in fields where spring cereals were sown in 1988. The crops were sown at the recommended seed rates: 450 viable seeds of barley and 600 seeds of wheat $\mathrm{m}^{-2}$. Various soil types from ranging from sandy clay to heavy clay were represented. The experimental plots $(4.0 / 5.0 \mathrm{~m} \mathrm{x} 12 \mathrm{~m})$ were ploughed to a depth of $20-25 \mathrm{~cm}$ every autumn.

Commercial herbicide formulations of MCPA/mecoprop-P (270/305 g a.i. l $^{-1}$, 'Duplosan KV-M') for use in wheat fields and MCPA/dichlorprop-P (265/285 g a.i. $\mathrm{l}^{-1}$, 'Duplosan DP-M') in barley fields were applied at their lowest recommended rates and at $30 \%$ lower rates. MCPA/fluroxypyr (400/100 g a.i. $\mathrm{l}^{-1}$, 'Starane M') was applied to both crops. In addition, tribenuronmethyl (750 $\mathrm{g} \mathrm{kg}^{-1}$ granular formulation, 'Express 75 DF') (FERGUSON et al. 1985) was used as a reference herbicide (Table 1).

New formulations of phenoxy acid herbicides containing only the optically active isomers of dichlorprop and mecoprop (SQUIRES et al. 1987) were

Table 1. Treatments in the field experiments in spring barley and spring wheat fields in 1989-1991. MCPA/dichlorprop-P was applied only in spring barley and MCPA/mecoprop-P only in spring wheat.

\begin{tabular}{lrr}
\hline \multirow{2}{*}{ Treatment } & \multicolumn{2}{c}{ Herbicide dose } \\
\cline { 2 - 3 } & \multicolumn{1}{c}{$\mathrm{l} \mathrm{ha}^{-1}$} & $\mathrm{~g} \mathrm{a.i.} \mathrm{ha}^{-1}$ \\
\hline Unsprayed & 0 & \\
MCPA/fluroxypyr & 0.70 & $280 / 70$ \\
MCPA/fluroxypyr & 1.00 & $400 / 100$ \\
MCPA/dichlorprop-P & 1.25 & $331 / 356$ \\
MCPA/dichlorprop-P & 1.75 & $464 / 499$ \\
MCPA/mecoprop-P $^{\prime}$ & 1.25 & $338 / 381$ \\
MCPA/mecoprop-P $^{1}$ & 1.75 & $473 / 534$ \\
Tribenuron-methyl $^{1)}$ & $7 \mathrm{~g}$ & 5.3 \\
\hline
\end{tabular}

\footnotetext{
1) Non-ionic surfactant ('Citowett') $0.05 \%$ was added to the spray solution (water volume $200 \mathrm{I} \mathrm{ha}^{-1}$ ).
} 
included in the experiments. The objective was to investigate whether the positive results of reducing the recommended doses of racemic mixtures (SALONEN 1992a) would apply also to new formulations. Fluroxypyr was introduced into the official screening trials in Finland in 1982 as a new herbicide for weed control in cereal crops, with particular effect on Galium aparine L. (PAUL et al. 1985).

Treatments were arranged as a randomized complete block design with four replicates. Herbicides were applied at the 3- to 4- leaf stage of the crop (Zadoks' scale 13-15 (ZADOKS et al. 1974)) with a portable van der Weij propane sprayer that delivered $2001 \mathrm{ha}^{-1}$ spray solution at a pressure of 300 $\mathrm{kPa}$.

Herbicides were applied between the end of May and mid-June, about one month after sowing. The temperature at the time of application ranged from 10 to $25^{\circ} \mathrm{C}$, and the relative humidity from 33 to $77 \%$.

The emergence of crops and weeds were monitored before the herbicide application. Crop development (growth stages) and weed emergence were recorded.

Weeds were assessed in $0.25 \mathrm{~m}^{-2}$ sample plots. Annual dicot weeds were counted 0-1 days before spraying (with some exceptions of 2-4 days delay). Furthermore, the weed infestation (number and airdry weight per unit area) was assessed one month after spraying and at harvest. The relative number of emerged weeds at the time of spraying herbicides was calculated by comparing the number of weeds $\left(\right.$ No. $\mathrm{m}^{-2}$ ) at spraying and one month later. Crop yield results are given at $15 \%$ moisture content.

The impact of different control regimes on the subsequent weed infestation was assessed one year after the 3-year trial period in 1992. Weeds were counted at the time of spraying herbicides in spring cereal fields.

\section{Statistical analysis}

Analysis of variance was applied to weed and crop data by introducing Year as a within-subject factor and Site, Treatment and Block as between-subject factors. The random factor Block was nested in the site. The biomass of weeds, as a dependent variable, was transformed with the common logarithm $\log (y+1)$ to achieve normal distribution and homogeneity of variances. Weed density (No. $\mathrm{m}^{-2}$ ) was transformed with square root. The data from unsprayed plots were excluded from the final statistical analyses. The effect of herbicide dose reduction was tested with single degree-of-freedom contrasts. The effect of weed infestation (density, biomass) on crop yield was tested with regression analysis. Statistical analyses were done with the General Linear Models procedure of the SAS statistical package (SAS Institute Inc. 1990).

\section{Results}

\section{Occurrence of weeds}

Weed density at the time of herbicide application varied within the range of 7-702 weeds $\mathrm{m}^{-2}$ (Fig. 1). Also, the relative number of weeds which emerged before herbicide application, compared with the number of weeds per unit area one month later, varied considerably (Fig. 2). On average, $72 \%$ of the annual dicotyledonous weeds emerged before spraying. Crop plants usually reached at least the second leaf stage (Zadoks' scale 12-13) before the first flush of weeds. Most weed seedlings were between the cotyledon stage and the first true-leaf stage at the time of herbicide application.

The predominant weed species in the experimental fields were typical of Finnish cereal fields (c.f. ERVIÖ and SALONEN 1987). The weed populations varied between sites (Table 2) and, to some extent, between years at the same site. The most frequent and abundant weed species were Chenopodium album L., Fumaria officinalis L., Lamium L. spp., Stellaria media (L.) Vill., Matricaria L. spp.(including Tripleurospermum inodorum Schultz Bip.) and Viola arvensis Murray. Volunteer turnip rape (Brassica rapa L. subsp. oleifera DC.) occurred in those fields (LOU, SAT) where there were trials with turnip rape some years before the experiment.

The weed biomass (air-dry weight, DW) in the untreated plots ranged from 0.4 (SE 0.2) to 61.5 (SE 
a)

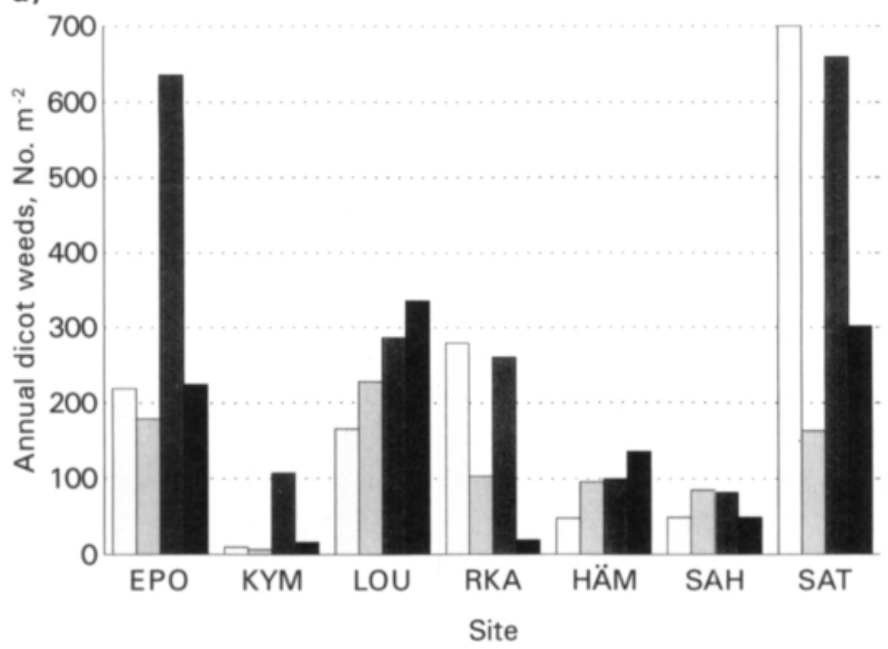

b)

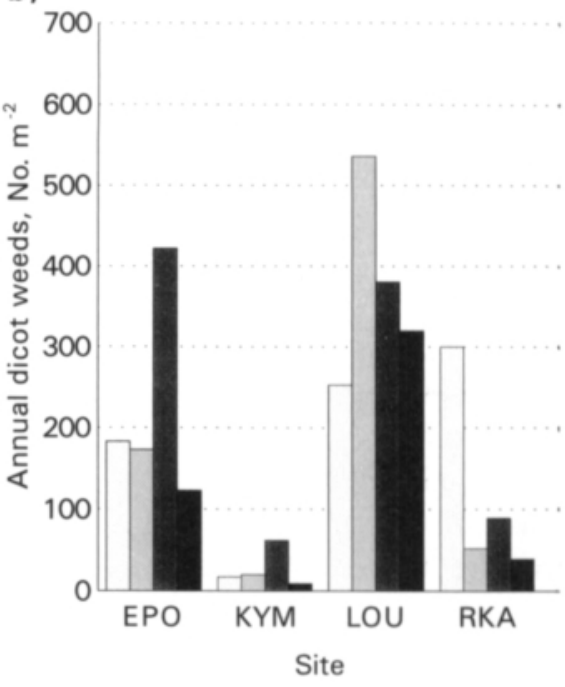

\section{$1989 \square 1990 \square 1991 \square 1992$}

Fig. 1. Weed infestation in the experimental fields at the time of herbicide application in a) spring wheat and b) spring barley. The experimental sites are: $\mathrm{EPO}=$ Ylistaro, $\mathrm{KYM}=$ Anjalankoski, $\mathrm{LOU}=$ Mietoinen, RKA $=$ Jokioinen, HÄM $=$ Pälkäne, $\mathrm{SAH}=$ Mouhijärvi, SAT $=$ Kokemäki.

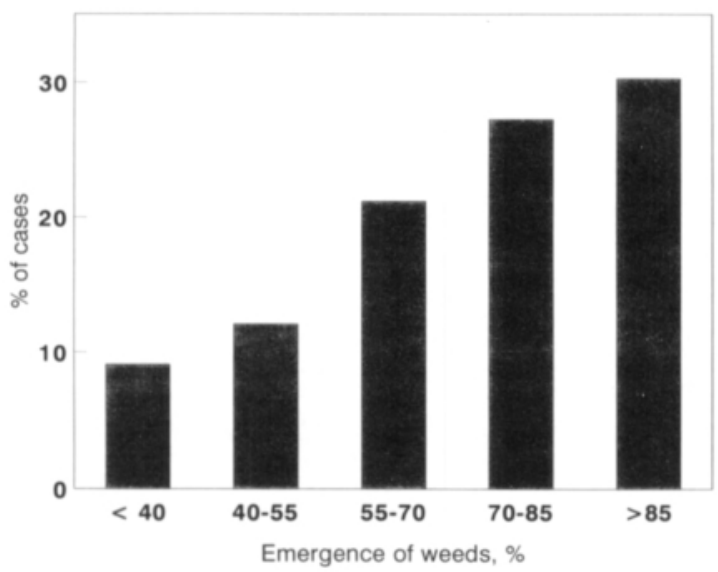

Fig. 2. Weed emergence in unsprayed plots at the time of herbicide application given as a percentage (five classes) of the weed density $\left(\mathrm{No} . \mathrm{m}^{-2}\right.$ ) one month later in 33 spring cereal experiments in 1989-1991.
Table 2. Predominant weed species in the experimental fields.

\begin{tabular}{lcccr}
\hline Site & & \multicolumn{2}{c}{ Weed species ${ }^{1)}$} & \\
\hline $\begin{array}{l}\text { Anjalan- } \\
\text { koski (KYM) } \\
\text { Jokioinen } \\
\text { (RKA) }\end{array}$ & CHEAL & FUMOF & GALSS & POLCO \\
$\begin{array}{l}\text { Kokemäki } \\
\text { (SAT) }\end{array}$ & BRSRO & CHEAL & THLAR & VIOAR \\
$\begin{array}{l}\text { Mietoinen } \\
\text { (LOU) }\end{array}$ & BRSRO & FUMOF & LAMSS & STEME \\
$\begin{array}{l}\text { Mouhijärvi } \\
\text { (SAH) }\end{array}$ & CHEAL & MYOAR & TRFPR & VIOAR \\
$\begin{array}{l}\text { Pälkäne } \\
\text { (HÄM) }\end{array}$ & CHEAL & MATSS & STEME & VIOAR \\
$\begin{array}{l}\text { Ylistaro } \\
(\text { EPO) }\end{array}$ & LAMSS & MATSS & POLCO & STEME \\
\hline
\end{tabular}

1) BAYER codes for weeds (BAYER 1992): BRSRO = Brassica rapa spp. oleifera $($ volunteer $), \mathrm{CHEAL}=$ Chenopodium album, FUMOF = Fumaria officinalis, GAESS = Galeopsis spp., GALS = Galium spp., LAMSS = Lamium spp., MATSS = Matricaria spp., $\mathrm{POLCO}=$ Fallopia convol vulus, $\mathrm{STEME}=$ Stellaria media, THLAR $=$ Thlapsi ar vense, TRFPR $=$ Trifolium pratense, $\mathrm{VIOAR}=$ Viola arven sis. 
12.2) $\mathrm{g} \mathrm{DW} \mathrm{m}^{-2}$ one month after herbicide application, and from 1.8 (SE 0.9) to 116.3 (SE 7.7) g DW $\mathrm{m}^{-2}$ at harvest. Biomass production varied considerably between weed species. Consequently, the total weed biomass in unsprayed plots, one month after spraying, weakly correlated $(r=0.48)$ with the total weed density at spraying. The most competitive weed species producing the highest biomass per plant were volunteer turnip rape $(0.60 \mathrm{~g} \mathrm{DW}$ plant $\left.{ }^{-1}\right)$, Galeopsis L. spp. (0.27 $\mathrm{g} \mathrm{DW}$ plant $\left.^{-1}\right)$ and Fallopia convolvulus (L.) A. Löve (0.15 g DW plant $\left.^{-1}\right)$. The biomass production of barley averaged $1.10 \mathrm{~g} \mathrm{plant}^{-1}$ and that of wheat $1.02 \mathrm{~g}$ plant $^{-1}$ at the four sites where both crops were grown in the same field.

\section{Herbicide efficacy}

Generally, all herbicides were effective when applied at the lowest recommended dose, and 30\% dose reduction reduced the efficacy, on average, by less than 10 percentage units (Fig. 3). However, a significant $(\mathrm{P}<0.001)$ Year*Site*Treatment interaction was detected (Table 3). This indicates that there were differences in the effectiveness of weed control between sites and between years within a site. Tribenuron-methyl was the most effective herbicide in most trials (Fig. 4), particularly when Matricaria spp. and Lamium spp. (EPO, LOU) were the predominant weed species.

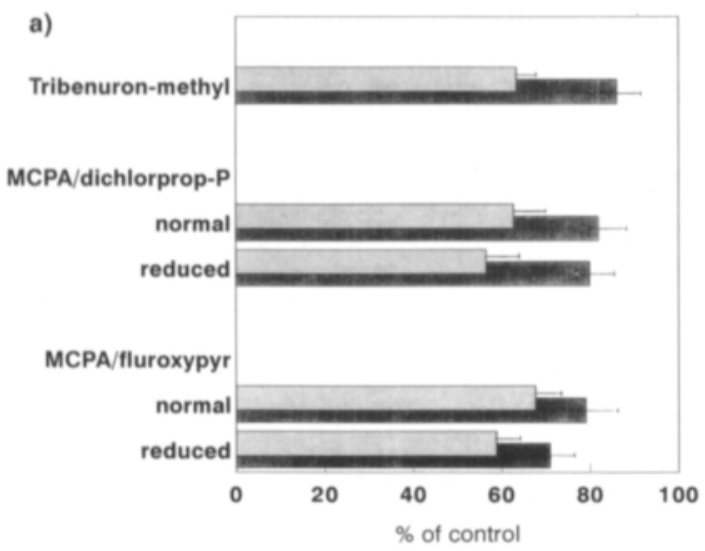

The reduction in herbicide efficacy was considered significant if $30 \%$ dose reduction caused more than $15 \%$ reduction in efficacy (on \%-scale) compared with the efficacy achieved with the recommended dose. In wheat trials such a reduction $(>15 \%)$ in the biomass-based efficacy occurred in $29 \%$ of plots treated with MCPA/mecoprop-P, and in $14 \%$ of plots treated with MCPA/fluroxypyr. The corresponding figures for barley trials were $8 \%$ with MCPA/dichlorprop-P and 19\% with MCPA/fluroxypyr.

To describe the probability of achieving a certain level of weed control, herbicide efficacy was calculated for each treatment within each replicate and the results were ranked in four efficacy classes (Fig. 5). Accordingly, treatment with reduced herbicide doses still provided at least $70 \%$ control in $70-89 \%$ of plots monitored. At the recommended herbicide doses the $70 \%$ efficacy level was reached in 78 $91 \%$ of cases.

Weed biomass in sprayed crop stands one month after herbicide treatment was less than $15 \mathrm{~g} \mathrm{DW} \mathrm{m}^{-2}$ in every trial. Dry weight of crop plants in unsprayed plots averaged 506 (SE 24) $\mathrm{g} \mathrm{DW} \mathrm{m}^{-2}$ in barley and 482 (SE 15) g DW m m $^{-2}$ in wheat. Dry weight of weeds was significantly $(\mathrm{P}<0.01)$ higher in unsprayed than in sprayed plots. To simplify the ANOVA analyses, data from the unsprayed plots were not included in the final analyses (Table 3). Only in some fields was the weed biomass signifi-

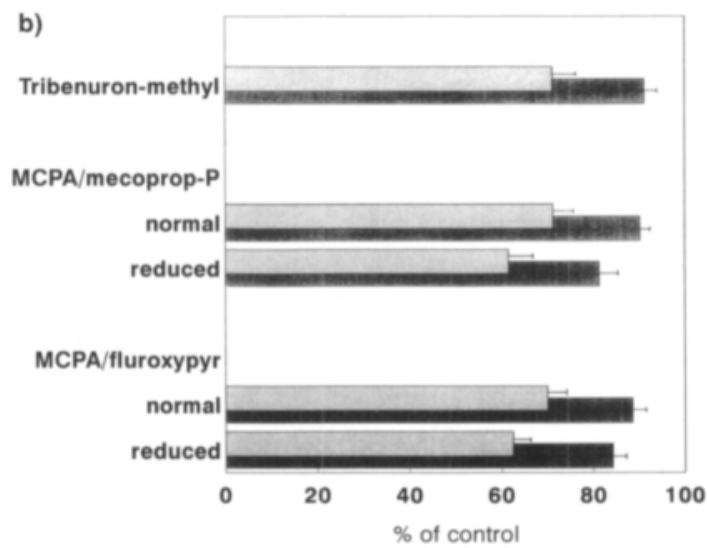

Fig. 3. Efficacy of herbicides determined as \% reduction of weed density (light bar) and dry weed biomass (dark bar). The mean efficacy and the SE of the mean in a) 12 spring barley trials and b) 21 spring wheat trials during 1989-1991. 


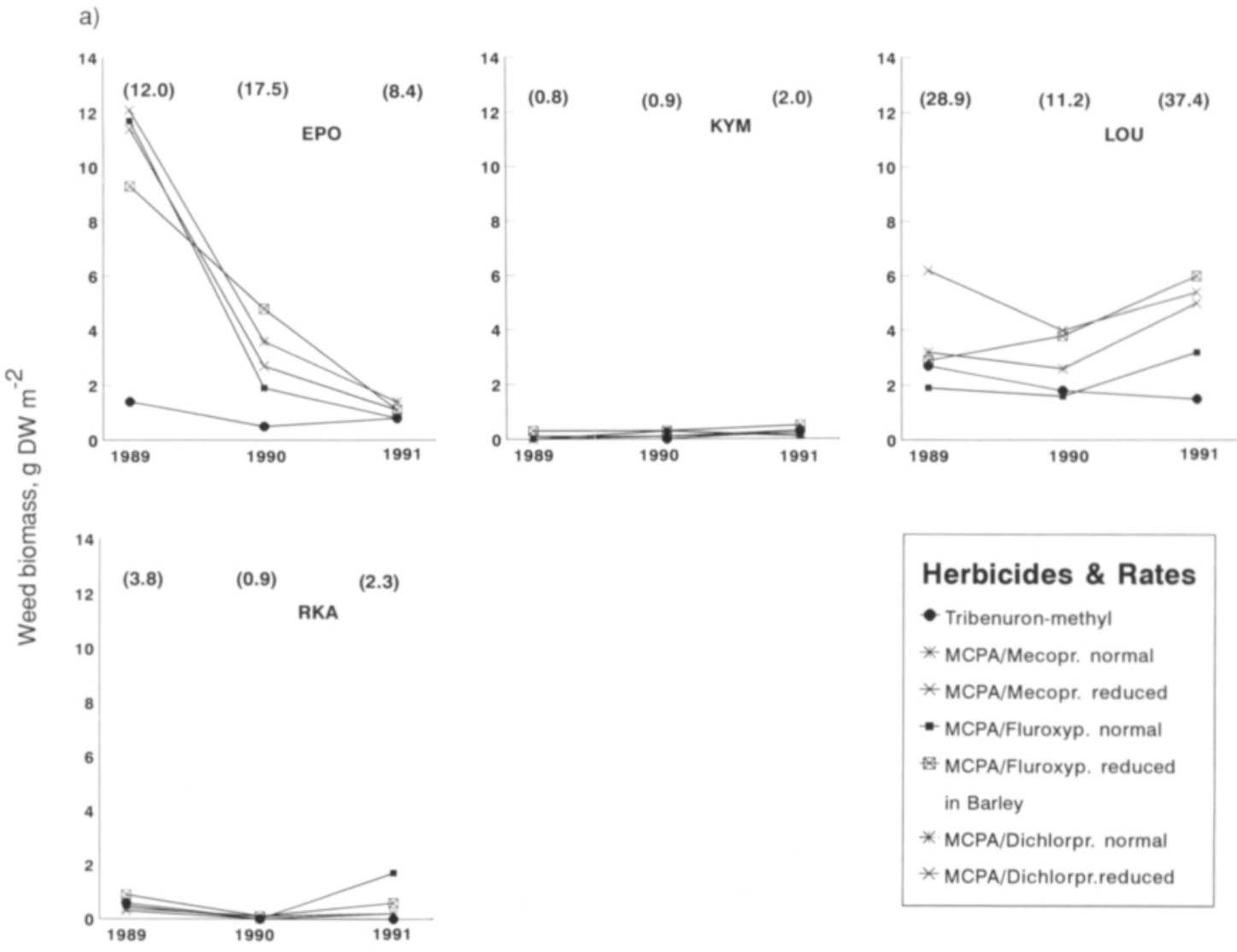

b)
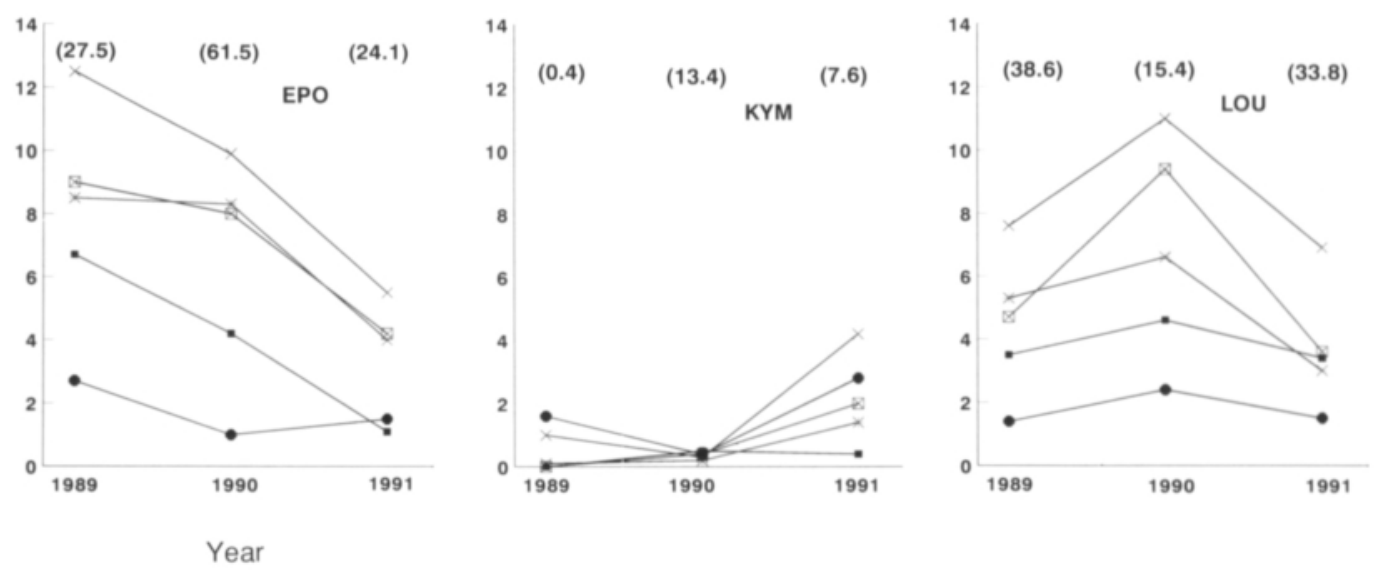
Fig. 4b) continues

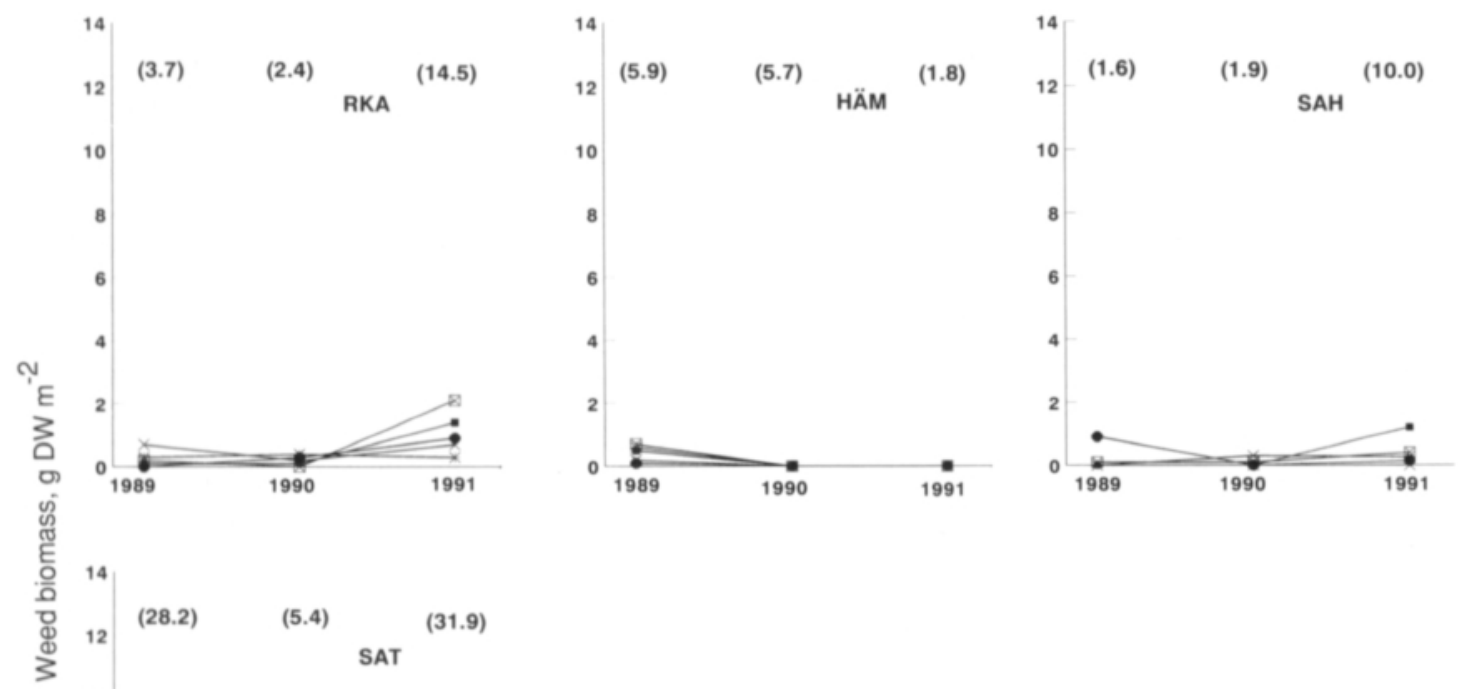

Fig. 4. Comparison of the remaining weed biomass in 1989-1991 in a) spring barley and b) spring wheat one month after treatment with different herbicide formulations and doses. The figures in paranthesis indicate the air-dry weed biomass $\left(\mathrm{g} \mathrm{m}^{-2}\right)$ in the unsprayed plots each year. The experimental sites are: $\mathrm{EPO}=$ Ylistaro, $\mathrm{KYM}=$ Anjalankoski, $\mathrm{LOU}=$ Mietoinen, $\mathrm{RKA}=$ Jokioinen, HÄM = Pälkäne, $\mathrm{SAH}=$ Mouhijärvi, $\mathrm{SAT}=$ Kokemäki.

cantly higher in the plots treated with reduced doses than in the plots treated with normal doses. In general, weeds produced more biomass in wheat stands than in barley stands (Fig. 4).

The dose reduction of MCPA/mecoprop-P decreased the effect of control particularly against Myosotis arvensis (L.) Hill, Matricaria spp., Polygonum L. spp. and Viola arvensis. Similarly, the dose reduction of MCPA/fluroxypyr significantly decreased (>10\%-units) the efficacy against $F u$ maria officinalis, Matricaria spp., Polygonum spp. and Viola arvensis. Conclusions concerning MCPA/dichlorprop-P were not drawn due to the limited number of observations.

\section{Crop-weed interactions}

The yield of spring barley and spring wheat averaged 4,900 kg ha- and 3,700 kg ha-1, respectively.
In the trial plots treated with herbicides the mean yield of wheat was $1.9 \%$ higher and barley yield was $4.0 \%$ higher than in untreated plots. The monetary value of such a yield increase ranges from FIM 150 to FIM 300 which is sufficient to cover the average cost of (FIM 100) herbicides for broadleaved weed control. Herbicide treatment did not reduce crop yield significantly $(\mathrm{P}<0.05)$ in any trial.

There was no significant difference in the mean crop yield from plots which received a recommended dose and those which received a reduced dose of herbicide. Only in one trial from 21 wheat trials did the dose reduction of MCPA/mecoprop-P result in a significantly $(\mathrm{P}<0.01)$ lower wheat yield, and once, in the same trial, with a reduced dose of MCPA/fluroxypyr $(\mathrm{P}<0.02)$.

The proportion of weed biomass from the total vegetative biomass of cereal fields was relatively low (Table 4). 
Table 3. Repeated measurements analysis of variance (ANOVA) of weed biomass $\log (\mathrm{Y}+1)$ in sprayed plots in spring barley at four sites and in spring wheat at seven sites. Trials were repeated for three years. Air-dry weight of weeds was measured one month after herbicide application.

\begin{tabular}{lll}
\hline Crop & $\begin{array}{l}\text { Degrees Type III } \\
\text { of F-value }\end{array}$ & $\begin{array}{l}\text { F-test } \\
\text { Mean }\end{array}$ \\
Source of variation & freedom Square &
\end{tabular}

\section{Spring barley}

Between-subject effect

\begin{tabular}{|c|c|c|c|c|}
\hline Site & 3 & 3.64 & 28.83 & $<0.001$ \\
\hline Error (1) & 10 & 0.13 & & \\
\hline Treatment & 4 & 0.21 & 8.82 & $<0.001$ \\
\hline Site* treatment & 12 & 0.11 & 4.72 & $<0.001$ \\
\hline Error (2) & 40 & 0.02 & & \\
\hline \multicolumn{5}{|l|}{ Within-subject effect } \\
\hline Year & 2 & 0.61 & 26.41 & $<0.001$ \\
\hline Year*site & 6 & 0.50 & 21.31 & $<0.001$ \\
\hline Error (3) & 20 & 0.02 & & \\
\hline Year*treatment & 8 & 0.02 & 1.43 & 0.20 \\
\hline Year*site*treatment & 24 & 0.05 & 2.91 & $<0.001$ \\
\hline Error (4) & 80 & 0.02 & & \\
\hline \multicolumn{5}{|l|}{ Spring Wheat } \\
\hline \multicolumn{5}{|l|}{ Between-subject effect } \\
\hline Site & 6 & 3.90 & 36.96 & $<0.001$ \\
\hline Error (1) & 18 & 0.11 & & \\
\hline Treatment & 4 & 0.29 & 15.51 & $<0.001$ \\
\hline Site*treatment & 24 & 0.12 & 6.38 & $<0.001$ \\
\hline Error (2) & 72 & 0.02 & & \\
\hline \multicolumn{5}{|l|}{ Within-subject effect } \\
\hline Year & 2 & 0.08 & 1.68 & 0.16 \\
\hline Year*site & 12 & 0.31 & 6.80 & $<0.001$ \\
\hline Error (3) & 36 & 0.05 & & \\
\hline Year*treatment & 8 & 0.02 & 1.80 & 0.56 \\
\hline Year*site*treatment & 48 & 0.03 & 1.30 & 0.12 \\
\hline Error (4) & 144 & 0.03 & & \\
\hline
\end{tabular}

Correlation between weed biomass at harvest and crop yield was weak $(\mathrm{r}<-0.50)$. Graphing data did not reveal any clear relationship between weed biomass and crop yield. The relationship between yield response and weed infestation (density, biomass) was analyzed with linear and non-linear regression. In these analyses the weed infestation accounted for less than $10 \%$ of the total variation in
Table 4. Proportion of weed biomass out of the total vegetative biomass in unsprayed and sprayed plots of spring barley and spring wheat. Assessments were made one month after herbicide application and at harvest. Mean percentage of 12 trials in spring barley and 21 trials in spring wheat in 19891991.

\begin{tabular}{lcc}
\hline & \multicolumn{2}{c}{ Weed biomass, \% $( \pm \mathrm{SE})$} \\
\cline { 2 - 3 } $\begin{array}{l}\text { Crop } \\
\text { Treatment }\end{array}$ & $\begin{array}{c}\text { One month } \\
\text { after spraying }\end{array}$ & At harvest \\
\hline Spring barley & & \\
unsprayed & $2.2(0.5)$ & $3.1(0.8)$ \\
sprayed & $0.5(0.1)$ & $0.4(0.1)$ \\
Spring wheat & & \\
unsprayed & & $3.6(0.6)$ \\
sprayed & $3.4(0.5)$ & $0.6(0.1)$ \\
\hline
\end{tabular}

crop yield. Thus, no reliable threshold value between weed infestation and crop yield response was found.

\section{Impact of weed control on the subsequent weed infestation}

The weed density in 1992, pooled across the sites, was significantly $(\mathrm{P}<0.05)$ higher in plots not sprayed with herbicide $\left(158\right.$ weeds $\left.\mathrm{m}^{-2}\right)$ than in sprayed plots ( 99 weeds $\mathrm{m}^{-2}$ ). Contrast comparison by site revealed no statistically significant $(\mathrm{P}<0.05)$ differences in the weed densities following from the recommended and the reduced rate applications of any herbicide formulation.

The subsequent effect of herbicide treatments on the weed infestation at spraying in the following years was analyzed with a repeated measurements analysis starting from 1990, one year after the start of the experiment, and including data from 1991 and 1992. A significant difference in weed densities in the unsprayed and sprayed plots was detected, but there was no significant $(\mathrm{P}<0.05)$ difference between weed densities in sprayed plots.

Significant changes in the species composition of weed populations due to the chemical control were not found. The start of the growing season in 1992 was extremely dry, and weed densities were low even in unsprayed plots. 
a)

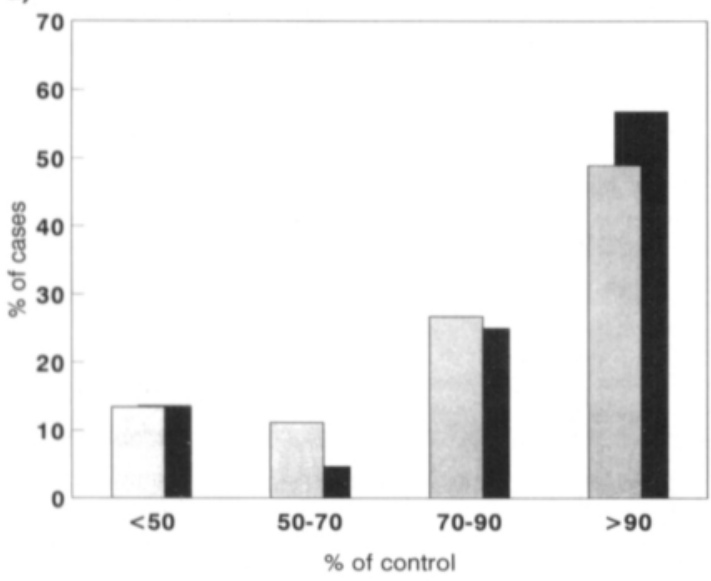

c)

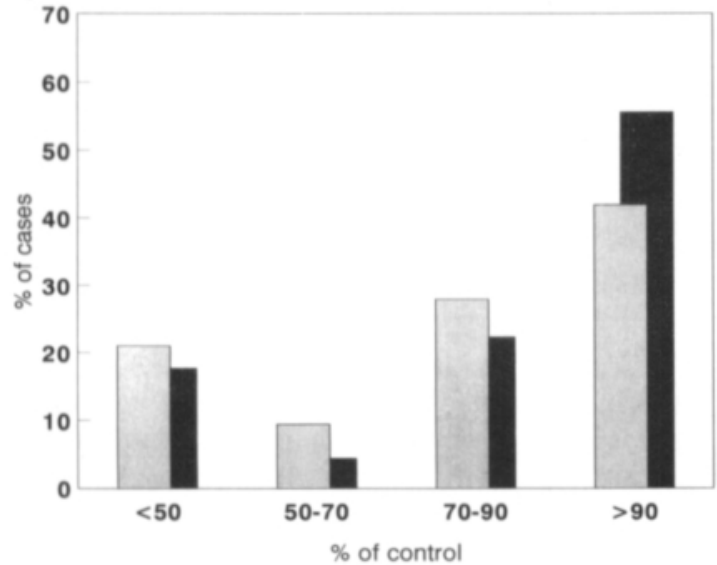

b)

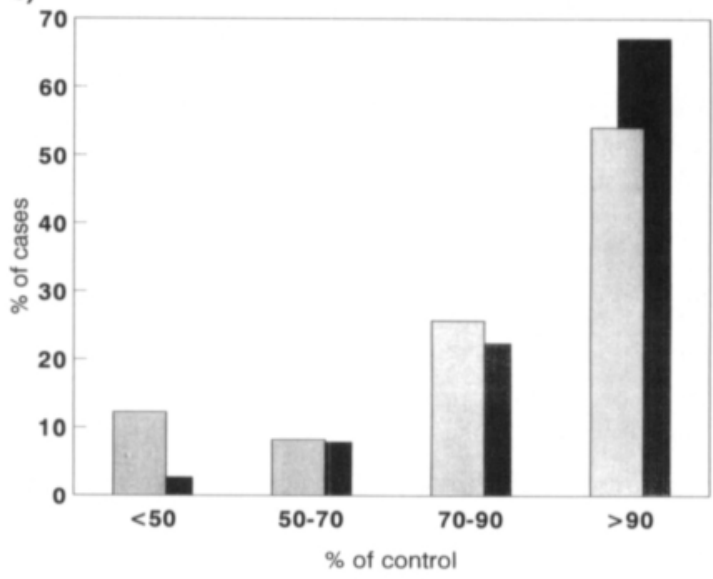

d)

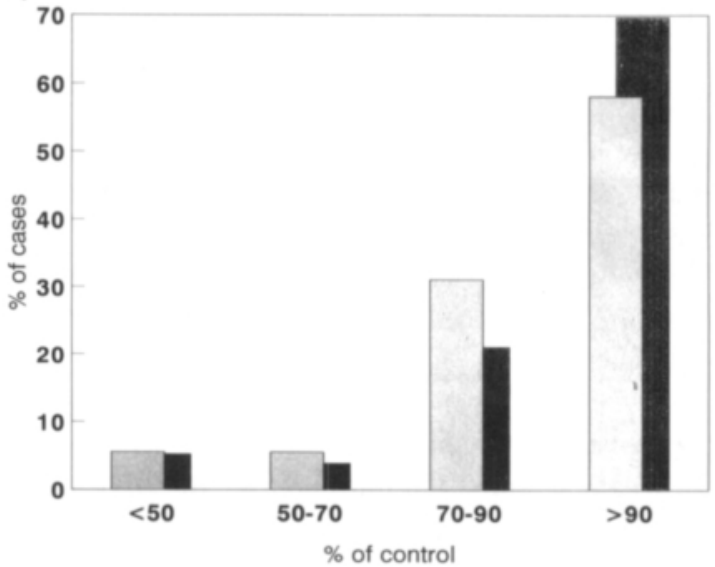

Fig. 5. Distribution of observations into four herbicide efficacy classes determined according to the \% reduction of weed biomass compared with that in the unsprayed plots. The efficacy achieved with the reduced (light bar) and the recommended (dark bar) doses of a) MCPA/dichlorprop-P in spring barley, b) MCPA/mecoprop-P in spring wheat, c) MCPA/fluroxypyr in spring barley and d) MCPA/fluroxypyr in spring wheat.

\section{Discussion}

Differential sensitivity of weed species to herbicides and species-specific dose responses were detected. The results are in accordance with those from earlier studies (e.g. PALLUTT 1988, SALONEN 1992a) and advocate careful annual decision-making for chemical control of weeds.

All herbicide formulations were found appropriate for use in fields of spring cereals in terms of weed-kill and crop safety. Tribenuron-methyl provided, on average, the best weed control (Fig. 3). MCPA/fluroxypyr had no clear advantage over other herbicides since Galium L. spp. did not occur frequently in the trials.

Herbicide formulations and the time of application (related to crop growth) were predetermined in our experimental protocol and not selected according to the prevailing weed species and their growth stages. Herbicide application according to crop growth stage resulted in low herbicide efficacy in some trials, particularly in terms of the effect on weed density (Fig. 3). This was due to late emerging weed seedlings, particularly in sparse crop stands. The delay in weed emergence was typical of dry growth conditions. Delayed herbicide applica- 
tion within the recommended treatment interval would obviously have given better efficacy in such situations. However, the time of application is not considered an equally important factor as the choice of herbicide (JUNNILA 1990).

The competition pressure of the annual dicotyledonous weeds was relatively low, and their proportion of the total vegetative biomass was often negligible compared with the crop biomass. This was evidently a consequence of the earlier emergence of the crop plants relative to the weeds. It is suggested that the relative time of emergence is an important factor in crop-weed competition (e.g., HÅKANSSON 1983, COUSENS et al. 1987, KROPFF 1988).

Crop yield responses to chemical weed control were small at normal and reduced herbicide doses. The largest yield increases, over yields from unsprayed plots, with herbicide application were achieved at LOU in 1989, where volunteer oilseed rape was the main weed species. Generally, the weed biomass was negligible compared with crop biomass. Consequently, no reliable relationship between weed infestation and yield response was established.

The herbicide rates applied were appropriate, since herbicide application did not cause any significant reductions in crop yields. The only visual phytotoxic symptom was a typical transient discoloration of crop foliage caused by tribenuronmethyl. In contrast, herbicide treatments have been shown to reduce crop yields (JENSEN 1985, DAVIES and WHITING 1990, SALONEN 1992b), particularly when unnecessarily high herbicide rates are applied. MAYES (1980) compared herbicide applications, with products based on phenoxy alkanoic acids, over a range of cereal growth stages. He concluded that, in the absence of weeds, crop yields were not depressed following application of herbicides at their recommended rates before the first node stage of crop. However, incidence of yield reduction was more frequent when high rates were applied at late crop growth stages.

Official recommendations for herbicide doses could be reduced by approximately $30 \%$ provided that conditions for the use of low doses were clearly stated on product labels. Failures in chemical weed control are likely to increase if farmers use reduced herbicide doses incautiously. The reductions in efficacy (Figs. 3, 4 and 5) will not inevitably lead to any long-term increase in weed infestation nor to crop yield reductions, since the current weed infestation and its influence on cereal stands is often low even in unsprayed fields (ERVIÖ et al. 1991). However, crop cover and evenness of crop stands are important factors in determining the optimal dose of herbicides (NIEMANN 1990).

Recommended rates of herbicide application are still needed against relatively tolerant weed species and in delayed applications against more developed weed seedlings. The product labels should, however, include some information about the possibilities to reduce doses. Primarily, these recommendations should be related to weed species. The available information about dose responses of different weed species is relatively comprehensive. Secondly, the precise time of herbicide application, during the early stages of weed growth, should be emphasized more than the crop growth stage.

A wide range of weed densities was recorded in the trials. Any clear tendency towards increasing weed densities could not be detected even in unsprayed plots within the 4-year recording period (Fig. 1). This was partly due to the extreme drought in 1992, which apparently hampered the weed emergence. Considerable and nonpredictable annual variation in weed density in spring cereal experiments has also been recorded e.g. in Norway (FYKSE 1993).

Reduced herbicide doses maintained the weed densities at the same level as the normal doses. Similar results were reported from Denmark by JENSEN (1991) who compared the effects of normal and a half normal doses of herbicides in spring barley fields over ten years. One explanation for good results with reduced herbicide doses is that reduced doses have been shown to suppress weed seed production to the same extent as normal doses (PEDERSEN and RASMUSSEN 1990, ANDERSSON 1993, RASMUSSEN 1993).

No reliable density-based threshold values for chemical weed control were established either in this study or in earlier experiments (BLEIHOLDER and NUYKEN 1986, DAVIES et al. 1989, ERVIÖ et al. 1991). A reduction in the rates of application of 
herbicides would represent a feasible means of reducing their use, with all the accompanying benefits for the environment, while maintaining weed infestation in cereal fields at the current low levels. Unfortunately, not all treatments are profitable in terms of crop yield increase (JENSEN 1985, ERVIÖ et al. 1991).

Although some results are pooled across years and sites, the main conclusion reached from the series of field experiments is that the decision-making for chemical weed control is a site-specific problem, and even seasonal variations should be considered. A broad range of herbicides is available for diverse weed control problems in cereals. The profitability of cereal production can be increased by choosing appropriate herbicide formulations, and by applying timely optimal doses.

Acknowledgements. I thank the representatives of BASF and DowElanco for providing the herbicide formulations at my disposal.

\section{References}

ANDERSSON , L. 1993. Inverkan av MCPA på fröproduktionen hos några ogräsarter. Proc. 34:e svenska växtskyddskonf., Ogräs och ogräsbekämpning. p. 49-58.

BAANDRUP, M. \& BALlEgAARD, T. 1989. Three years field experience with an advisory computer system applying factor-adjusted doses. Proc. Brighton Crop Prot. Conf. Weeds. 2: 555-560.

BAYER 1992. Important crops of the world and their weeds. 2nd ed. Bayer AG. Leverkusen. 1681 p.

BleiHOldER, H. \& NUYKEN, W. 1986. Neue Ansätze zur Darstellung und Interpretation des Zusammenhanges zwischen den Deckungsgrad der Unkräuter und dem Ertrag von Getreide. Proc. EWRS Symp. Economic Weed Control. p. 331-336.

Cousens, R., Brain, P., O'Donovan, J.T. \& O'Sullivan, A. 1987. The use of biologically realistic equations to describe the effects of weed density and relative time of emergence on crop yield. Weed Sci. 35: 720-725.

DAVIES, D.H.K. \& WhITING, A.J. 1990. Effect of reduced herbicide dose on weed growth and crop safety in cereals and consequences for grain quality and harvesting. Proc. EWRS Symp. Integrated Weed Management in Cereals. p. 331-336.

—, Whiting, A.J. \& Whytock, G.M. 1989. Yield responses to herbicide use and weed levels in winter wheat and spring barley in Scottish trials and consequences for economic models. Proc. Brighton Crop Prot. Conf. Weeds. 3: 955-960.

ERviö, L.-R. \& SAlonen, J. 1987. Changes in the weed population of spring cereals in Finland. Ann. Agric. Fenn. 26: 201-226.

— , Tanskanen, T. \& Salonen, J. 1991. Profitability of chemical weed control in spring cereals. Ann. Agric. Fenn. 30: 199-206.

Ferguson, D.T., Schehl, S.E., Hageman, L.H., Lepone, G.E. \& CARRARO, G.A. 1985. DPX-L5300 - a new cereal herbicide. Proc. Brit. Crop Prot. Conf. - Weeds. 1: 43-48.

FoGElFors, H. 1990. Different doses of herbicide for control of weeds in cereals - final report from the long-term series. Proc. 31st Swedish Crop Prot. Conf. p. 139-151.
FYKSE, H. 1993. Dynamics of weeds in long-term experiments in spring cereals. Proc. EWRS Symp. Quantitative Approaches in Weed and Herbicide Research. 2: 689696.

HảKANSSON, S. 1983. Competition and production in shortlived crop-weed stands. Swedish Univ. Agric. Sci., Dept. Plant Husb., Report 127. Uppsala. 85 p.

Hynninen, E.-L. \& BlomQvist, H. 1993. Pesticide sales in Finland 1992. Kemia-Kemi. 20: 535-537.

JENNÉUS, B. 1991. Reducerade doser av ogräsmedel i stråsäd. Resultat från demonstrationsodlingar. Proc. 32:a svenska växtskyddskonf., Ogräs och ogräsbekämpning. p. 39-51.

JENSE N, P.K. 1985. A review of yield responses to weed control in one thousand spring barley experiments. Proc. 1985 Brit. Crop Prot. Conf. - Weeds. 2: 687-692.

— 1991. Behov og økonomi ved ukrudtsbekæmpelse i landbrugsafgøder. Møder om planteværn 1991, Landbrugsafgrøder. p. 14-16.

JUNNILA , S. 1990. Influence of spraying time on herbicide efficacy in spring cereals. Proc. EWRS Symp. Integrated Weed Management in Cereals. p. 375-382.

KEMMer, A. \& HURLE, K. 1990. Untersuchungen zur Reduzierung des Herbizidaufwandes bei der Unkrautbekämpfung in Getreide. Proc. 47. Deutsche Pfl.schutzTagung. Mitt. Biol. Bundesanst. f. Land- u. Forstw., Heft 266. p. 377.

KROPFF, M.J. 1988. Modelling the effects of weeds on crop production. Weed Res. 28: 465-471.

KUDSK, P. 1989. Experiences with reduced herbicide doses in Denmark and the development of the concept of factor-adjusted doses. Proc. Brighton Crop Prot. Conf. Weeds. 2: 545-554.

Markiula, M., Titttanen, K. \& Vasarainen, A. 1990. Torjunta-aineet maa- ja metsätaloudessa 1953-1987. Maatalouden tutkimuskeskus, Tiedote 2/90. 58 p.

MAYES, A.J. 1980. The influence of application time on cereal yield of products based on substituted phenoxy alkanoic herbicides. Proc. Brit. Crop Prot. Conf. - Weeds. 1: 77-83. 
Niemann, P. 1990. Zur Häufigkeit von Bestandeslücken und deren Bedeutung für die Verunkrautung. Z. Pfl.krankh. Pfl.schutz, Sonderh. 12: 59-69.

PAllutT, B. 1988. Beträge zur integrierten Unkrautbekämpfung im Getreideanbau. Akad. Landw. der DDR. Berlin. 129 p. (Diss.).

Paul, J.A., Sutton, P.B., Skidmore, A.M. \& Score, D.J. 1985. FF4014: a new broad spectrum cereal herbicide based on fluroxypyr. Proc. Brit. Crop Prot. Conf. Weeds. 3: 939-946.

Pedersen, J.O. \& RASMUSSEN, I.A. 1990. Herbiciders inflydelse på ukrudets fröproduktion. Proc. 7. Danske Plantev.konf. 1990, Ukrudt. p. 73-83.

Proven, M.J., Courtney, A., Picton, J., Davies, D.H.K. \& Whiting, A.J. 1991. Cost-effectiveness of weed control in cereals - systems based on thresholds and reduced rates.Proc. Brighton Crop Prot. Conf. - Weeds. 3: 12011208.

RASMUSSEN, I. 1993. Seed production of Chenopodium album in spring barley sprayed with different herbicides in normal to very low doses. Proc. EWRS Symp. Quantitative Approaches in Weed and Herbicide Research. 2: 639-646.

SALONEN, J. 1992a. Efficacy of reduced herbicide doses in spring cereals of different competitive ability. Weed Res. 32: 483-491.
- 1992b. Yield responses of spring cereals to reduced herbicide doses. Weed Res. 32: 493-499.

SAS Institute Inc. 1990. SAS/STAT® User's Guide, Vers. 6, 4th ed., Vol 2. SAS Inst. Inc. Cary, NC. 848 p.

Squires, N.R.W., RadTKE, M. \& HunT, B.S. 1987. New formulations of phenoxypropionic herbicides containing only the herbicidally active isomer for the control of broad-leaved weeds in cereals. Proc. 1987 Brit. Crop Prot. Conf. - Weeds. 1: 225-231.

THONKE, K. E. 1991. Political and practical approaches in Scandinavia to reduce herbicide inputs. Proc. Brighton Crop Prot. Conf. - Weeds. 3: 1183-1190.

ZadoKs, J.C., Chang, T.T. \& KonZaK, C.F. 1974. A decimal code for growth stages of cereals. Weed Res. 14: 415421.

Ympäristöministeriö 1992. Ehdotus maaseudun ympäristöohjelmaksi. Ympär.suoj.os., Työryhmämiet. 68/92. Helsinki. 49 p.

\section{Manuscript received September 1993}

Jukka Salonen

Agricultural Research Centre of Finland

Institute of Plant Protection

FIN-31600 Jokioinen, Finland 


\title{
SELOSTUS
}

\section{Pienennettyjen herbisidiannosten toimivuus kevätviljojen rikkakasvintorjunnassa}

\author{
JUKKA SALONEN
}

Maatalouden tutkimuskeskus

Kolmevuotisessa (1989-1991) seitsemälle koepaikalle sijoitetussa tutkimuksessa selvitettiin mahdollisuutta pienentää viljaherbisidien käyttömääräsuositusta. MCPA/diklorproppi-P, MCPA/mekoproppi-P ja MCPA/fluroksipyyri ruiskutettiin kevätvehnä- ja ohrakokeissa pienimmällä suositellulla ja $30 \%$ pienemmällä annoksella. Verrannevalmisteena oli pienannosherbisidi tribenuroni-metyyli. Kolmen koevuoden aikana toteutettiin yhteensä 21 kevätvehnäkoetta ja 11 ohrakoetta.

Rikkakasvien määrä ruiskutushetkellä vaihteli 7-702 $\mathrm{kpl} / \mathrm{m}^{2}$, jolloin rikkakasveista oli taimettunut keskimäärin 72 $\%$ verrattuna kuukauden kuluttua mitattuun rikkakasvien määrään. Rikkakasvien kasvutiheyden perusteella ei voitu ennustaa viljakasvustoon kesän mittaan muodostuvaa rikkakasvimassaa, sillä rikkabiomassan tuotanto vaihteli rikkakasvilajien, viljan kilpailukyvyn ja sääolojen mukaan. Rikkakasvien tuottama ilmakuiva biomassa vaihteli suuresti vuosittain ja koepaikoittain välillä $0.4-61.5 \mathrm{~g} / \mathrm{m}^{2}$ kuukauden kuluttua herbisidiruiskutuksesta ja välillä $1.8-116.3 \mathrm{~g} / \mathrm{m}^{2}$ puintihetkellä.

Herbisidiannoksen vähentäminen $30 \%$ :lla heikensi torjuntatehoa keskimäärin alle $10 \%$-yksikköä. Yli $15 \%$-yksikön tehon heikkeneminen havaittiin kevätvehnäkokeissa MCPA/mekoproppi-P:Ilä $29 \%$ :ssa kokeista ja MCPA/fluroksipyyrillä $14 \%$ :ssa kokeista, sekä ohrakokeissa MCPA/diklorpropilla $8 \%$ :ssa kokeista ja MCPA/fluroksipyyrillä $19 \%$ :ssa kokeista.

Pienemmillä annoksilla herbisidit vähensivät rikkakasvimassaa $75 \%$ ohrakokeissa ja $83 \%$ kevätvehnäkokeissa ruiskuttamattomaan verrattuna. Vaikka suositellun annoksen pienentäminen heikensi toisinaan huomattavasti \%-yksiköissä laskettua torjuntatehoa, ei kasvustoon useinkaan jäänyt viljelykasvin kannalta haitallisia määriä rikkakasveja. Monesti rikkakasvien tuottama biomassa oli ruiskuttamat- tomissakin ruuduissa vähäinen, keskimäärin noin $3 \%$ viljakasvuston kokonaisbiomassasta.

Rikkakasvitorjunnan jälkivaikutus selvitettiin vuonna 1992 laskemalla rikkakasvien määrä ruiskutushetkellä. Ruiskuttamattomissa ruuduissa rikkakasvien lukumäärä $\left(158 \mathrm{kpl} / \mathrm{m}^{2}\right)$ oli keskimäärin suurempi kuin ruiskutetuissa ruuduissa $\left(99 \mathrm{kpl} / \mathrm{m}^{2}\right)$. Eri koepaikkojen välillä oli suuria eroja taimettuneiden rikkakasvien määrässä, mutta herbisidiannoksen vähentäminen ei missään kokeessa lisännyt merkitsevästi rikkakasvien määrää. Alkukesän kuivuus vuonna 1992 haittasi rikkakasvien taimettumista, eikä taimettuneiden rikkakasvien määrä välttämättä kuvannut maan rikkasiemenvarastoa eri koejäsenten välillä.

Rikkakasvien aiheuttamat satotappiot jäivät useimmissa tämän tutkimuksen kenttäkokeissa hyvin pieniksi. Herbisidiruiskutus lisäsi kevätvehnän satoa keskimäärin $1,9 \%$ ja ohran satoa 4,0 \%. Luotettavaa kynnysarvoa herbisidien käytöstä luopumiselle ei kuitenkaan voitu määrittää, sillä rikkakasvien lukumäärä ruiskutushetkellä ei kuvannut niiden kesän kuluessa tuottamaa biomassaa ja siitä aiheutuvaa viljasadon vähentymistä. Kuukauden kuluttua ruiskutuksesta herbisidiä kestäneiden ja ruiskutuksen jälkeen taimettuneiden rikkakasvien tuottama ilmakuiva biomassa oli kaikissa kokeissa alle $15 \mathrm{~g} / \mathrm{m}^{2}$, kun kevätvehnän biomassa oli keskimäärin $482 \mathrm{~g} / \mathrm{m}^{2}$ ja ohran $506 \mathrm{~g} / \mathrm{m}^{2}$.

Tutkimustulokset puoltavat herbisidien myyntipäällyksessä ilmoitettujen annossuositusten pienentämistä noin 30 $\%$ tilanteissa, joissa herbisidi valitaan rikkakasvilajiston mukaan ja ruiskutus ajoitetaan rikkakasvien varhaiselle taimivaiheelle. Erittäin hyväkuntoisessa viljakasvustossa voidaan vähäisiä rikkakasvimääriä torjua vieläkin pienemmällä herbisidimäärällä. Herbisidiannoksen tarkentamisen toivotaan johtavan herbisidien käytön vähentämiseen tavalla, jolla estetään rikkakasvien määrän lisääntyminen pelloilla. 